\title{
IDEAL OCH VERKLIGHET I DEN LOKALA DEMOKRATIN: EN STUDIE AV 1990-TALETS LOKALA POLITIKER
}

Magnus Hagevi, Institutionen för statsvetenskap, Linnéuniversitetet E-post I magnus.hagevi@lnu.se

"Revolution." Så löd en kommentar när Ragunda kommunfullmäktige beslutat att från och med år 1992 kraftigt minska antalet nämnder och politiska uppdrag i den jämtländska kommunen (se Dagens Nyheter 6/10 1992). Sedan 1990-talets början har flera kommuninvånare upplevt liknande omvälvningar. Antalet nämnder, kommunala uppdrag och lokala politiker i kommunerna har kraftigt minskat (Hagevi 2000:39-42; Järnberg \& Olofsson 2011:11-12). De som beslutat om en minskad politisk organisation har talat om fördjupad demokrati, effektivitet och ökad politisk styrning. Kritikerna har istället talat om nämndslakt och varnat för

(C) 2015 Magnus Hagevi. Detta är en Open Access artikel distribuerad under CC-BY-NC som innebär att du tillåter andra att använda, sprida, göra om, modifiera och bygga vidare på ditt verk, men inte att verket används i kommersiella sammanhang. http://dx.doi.org/10.15626/sj.20151202 
en försvagning av den svenska demokratin. Flera kommuner har också haft ekonomiska problem. Som ett led i att bekämpa budgetunderskott har en del kommuner minskat antalet politiska uppdrag (se t.ex. Nerikes Allehanda 28/9 1999). Sambandet mellan kommunernas ekonomiska ställning och de politiska organisationernas omfång var dock osäkert (Hagevi 2000:32-34). På 1990-talet var därför det ekonomiska argumentet ihåligt om det inte parades med lokalpolitikernas grundläggande värderingar.

Besluten har kunnat genomföras i och med den nya kommunallag som trädde ikraft år 1992. Enligt den då nya lagen fick kommunerna stor frihet att själva besluta om hur den egna politiska organisationen skulle utformas. Förutom kommunfullmäktige och kommunstyrelse ålades endast kommunerna att ha valnämnd och kommunrevision. Dess två obligatoriska nämnder var de enda som krävdes efter reformen jämfört med de fem obligatoriska nämnder som krävdes före år 1992.

Riksdagen fattade beslutet om den fria nämndorganisationen med stor enighet. ${ }^{1}$ Ändå oroades riksdagens konstitutionsutskott för utsikterna att landets kommuner nu skulle utnyttja lagen och minska antalet kommunalt förtroendevalda:

Utskottet är medvetet om att en friare nämndorganisation kan medföra vissa problem ur kommunaldemokratisk synpunkt. Den nedåtgående trend vad gäller antalet förtroendevalda som funnits alltsedan 1950-talet måste på sikt brytas (Riksdagens konstitutionsutskott, betänkande 1990/91:KU38).

I konstitutionsutskottets betänkande framskymtade ett visst demokratiskt ideal där det önskvärda var ett högt deltagande $i$ form av många kommunalt förtroendevalda politiker. Kraven på färre politiker och den faktiska utvecklingen gick stick i stäv mot ett omhuldat ideal inom svensk representativ demokrati: deltagaridealet (Demokratiutredningen 2000; Hagevi 2000:16-19; Gilljam \& Jodal 2002; Gilljam m.fl. 2010: 39-42; Esaiasson m.fl. 2011; Karlsson \& Gilljam 2014:74-79). Detta ideal värnade ett utbrett politiskt deltagande bland medborgarna. Det var en av anledningarna till att det fanns tusentals politiska uppdrag i Sveriges kommuner. 
Sedan länge bestod den lokala representativa demokratin av kommunfullmäktige, kommunstyrelse och övriga kommunala nämnder. I centrum stod en grupp av politiker som har givits flera olika namn. De kommunalt förtroendevalda, kommunpolitikerna, de lokala politikerna var några exempel på vad de kallades, men detta var olika namn på en gemensam grupp av politiska aktörer: de som innehade politiska uppdrag i den lokala representativa demokratin. Det var dessa lokala politiker som allt mer började ifrågasättas under 1990-talet. Som redan noterades ovan var det sedan början av 1990-talet kommunpolitikerna som förhållandevis fritt kunde skapa de regler som de själva verkade under. Det var de som fattade de huvudsakliga politiska besluten om den kommunala politiska organisationens utformande. Därför riktar denna studie strålkastarljuset på de lokala politikerna. Det tycktes som om lokalpolitikerna under 1990-talet ställdes inför två alternativ. Det ena alternativet antingen underkände eller negligerade varningarna om minskad effektivitet och bejakade möjligheten att upprätthålla ett högt politiskt deltagande i form av olika förtroendeuppdrag i kommunerna. Det andra alternativet tog till sig idén om ökad effektivitet genom en slimmad politiskt organisation i kommunerna och/eller en vision av ett annat demokratiskt ideal som var mer väljarinriktat.

Frågan är om det under 1990-talet fanns någon grogrund bland de svenska lokalpolitikerna för en sådan kommunalpolitisk revolution; fanns det bland dessa ett ifrågasättande av idealet om ett omfattande kommunalpolitiskt deltagande? Eller omhuldade 1990-talets lokalpolitiker deltagaridealet, trots att "slakten" av kommunala nämnder och därmed en stor mängd politiska uppdrag inleddes under denna tid?

För att analysera dessa frågor kommer jag att $\mathrm{i}$ denna studie presentera resultaten av en unik enkätundersökning av kommunpolitikernas demokratisyn på 1990talet. Men hjälp av denna studie är det möjligt att se att 1990-talets lokalpolitiker inte alls stödde nedskärningen av antalet kommunala förtroendeuppdrag, utan alltjämt var varma anhängare av deltagaridealet. Istället syntes det vara i respons till väljarnas krav som lokalpolitikernas krympte den politiska organisationen i kommunerna tvärtemot deltagaridealet. Jag kommer också att visa att det trots allt fanns en gradskillnad mellan politiker som företrädde olika partier: störst var skillnaderna mellan miljöpartistiska kommunalpolitiker som starkt stödde deltagaridealet, medan många moderata kommunalpolitiker var avvaktande. 


\section{Deltagaridealet}

I samband med kommunsammanslagningarna i början av 1970-talet minskade antalet kommunala förtroendeuppdrag i kommunerna kraftigt. År 1964 - innan kommunsammanslagningarna - fanns det 187000 förtroendeuppdrag i kommunerna. När sammanslagningarna genomförts år 1974 var antalet 75000 förtroendeuppdrag (Strömberg \& Westerståhl 1984). Bland annat riksdagens konstitutionsutskott uttrycktes under 1990-talet oro för den nedåtgående trenden. Anledningen till att riksdagsledamöterna i konstitutionsutskottet oroade sig var att ett minskat antal kommunalt förtroendevalda antogs leda till att medborgarna skulle få svårare att vara delaktiga i det politiska arbetet.

En viktig fråga i sammanhanget är självfallet hur de förtroendevaldas villkor kommer att gestalta sig i framtiden med de organisatoriska förändringar som nu föreslås $\mathrm{i}$ fråga om en friare nämndorganisation m.m. Som framhålls i propositionen är det av största betydelse att underlätta för medborgarna att engagera sig i det kommunalpolitiska arbetet. En viktig uppgift är att skapa likvärdiga förutsättningar för dem som är beredda att ta på sig politiska förtroendeuppdrag. (Riksdagens konstitutionsutskott, betänkande 1990/91:KU38).

Riksdagens konstitutionsutskott anknöt därmed till deltagaridealet. Detta ideal värnade ett utbrett politiskt deltagande bland medborgarna. Även regeringens justitiedepartement uttryckte år 1999 en normativ ståndpunkt som stödde deltagaridealet:

Ett aktivt och mångfasetterat medborgerligt deltagande i samhällslivet gör det möjligt att omsätta demokratins idéer i medborgarens vardag. Det behövs en demokratisk fördjupning där medborgarens deltagande sätts $i$ förgrunden [...]. Kommuner och landsting bör därför söka efter arbetsformer som ger alla medborgare reella möjligheter att åta sig förtroendeuppdrag. Därigenom kan allsidigheten öka i de politiska diskussionerna, representativiteten bland de förtroendevalda förbättras och medborgarnas erfarenheter, kunnande, kreativitet och engagemang tas till vara (Justitiedepartementet, direktiv 1999: 98). 
Deltagaridealet var dock inte något unikt för Sverige. I den klassiska statsvetenskapliga litteraturen var en av de främsta förespråkarna för ett omfattande politiskt deltagande engelsmannen och 1800-talsfilosofen John Stuart Mill. I On representative government (1861) argumenterar han för att varje medborgare någon gång under sin levnad ska ha innehaft ett politiskt förtroendeuppdrag. Mill menade att ett omfattande folkligt deltagande skulle ha två betydande effekter. För det första skulle alla viktiga åsikter representeras när beslut fattades. För det andra skulle medborgarna i sitt ansvarstagande tvingas att inte bara tänka på sig själva, utan att även tänka på andra människor och samhället i stort. Detta skulle innebära att människorna utvecklades till att bli mindre egoistiska och mer ansvarskännande för sina medmänniskor. ${ }^{2}$

\section{Lika möjligheter}

Möjligheten till lika politiskt inflytande betraktas vanligen som ett grundläggande demokratiskt värde (Dahl 1989). Det är värt att notera att det inte var på grund av detta värde som Mill förordade ett omfattande deltagande. Däremot har andra hävdat att ett omfattande deltagande är nödvändigt för att i så stor utsträckning som möjligt ge alla medborgare lika möjlighet till inflytande (se Lewin 1970; Szücs 1998). I samband med denna diskussion har man kunnat konstatera en motsättning mellan representativ demokrati och möjligheten till lika inflytande. Det är endast i de allmänna valen som alla har lika stora möjligheter till inflytande. I och med att vissa agerar som förtroendevalda har dessa större inflytande än de övriga väljarna mellan de allmänna valen (Held 1987; Scücs 1998).

Allas lika möjligheter till inflytande är ett svårlöst demokratiskt dilemma. Längst har de gått som menar att direktdemokrati - där alla deltar i besluten till exempel i folkomröstningar eller i kommunstämmor - är den enda formen av demokrati som är värd namnet (Barber 1984; jfr Rousseau 1762). Problemet är att direktdemokrati ännu är opraktiskt och svårt att genomföra annat än i mycket små enheter. Alltjämt gäller Mills gamla konstaterande: i ett land är de flesta politiska enheter för stora för att styras med direktdemokrati.

En föreslagen lösning på dilemmat är då att förorda ett högt politiskt deltagande. Man har talat om deltagardemokrati. För att uppnå högt politiskt deltagande har 
svenska kommuner sedan länge experimenterat med flera alternativa former av medborgerliga möjligheter att påverka. En sådan möjlighet är så kallat brukarinflytande. De som personligen berörs av kommunal verksamhet och nyttjar den kontinuerligt under en längre period kallas för brukare (Olsen 1991). I denna verksamhet har brukarna möjlighet att delta i och påverka beslut och hur besluten utförs. Ett demokratiskt problem är att inte heller dessa åtgärder ger möjligheten till ett lika politiskt inflytande. Även om deltagande i alternativa former innebär att fler är med och påverkar kvarstår problemet att inte alla deltar. Inflytandet är därmed fortfarande ojämnt fördelat (Jarl 1999).

\section{Deltagaridealet i representativ demokrati}

Betonandet och utvecklingen av alternativa metoder att påverka har gått så långt att deltagardemokrati ibland har setts som motsats till representativ demokrati. Medborgarnas politiska deltagande anses då ske utanför det representativa systemet. De förtroendevalda håller sedan en dialog med de aktörer som deltar politiskt utanför den representativa demokratin i syfte att möta folkliga krav (Held 1987; se även Montin 1998).

Vad som då glömts bort är att medborgerligt politiskt deltagande i högsta grad är möjligt även inom den representativa demokratin. Flera forskare menar också att deltagardemokrati inte står i motsats till representativ demokrati, utan snarare innebär att deltagande är betydelsefullt både i allmänna val och i offentliga representativa organ såväl som i andra alternativ (Pateman 1970; Lewin 1970; Barber 1984; Nagel 1987; Gould 1988; Olsen 1991; Holmberg 1999; Jarl 1999). Ett stort antal förtroendevalda i kommunerna ger goda möjligheter för kommuninvånarna att själva vara förtroendevalda någon gång under livet.

Det bör även framhävas att folkvalda politiker agerar på en annan demokratisk plattform än andra politiska aktörer. Agerandet hos exempelvis kommunpolitiker legitimeras av att de fătt sitt förtroende genom val med allmän och lika rösträtt. I en representativ demokrati av svensk typ är det endast i sådana val som möjlighet till lika inflytande föreligger. Det politiska deltagandet inom den representativa demokratins ram är således ett centralt inslag i deltagardemokratin, om inte rentav den centrala komponenten. Att undersöka det politiska deltagandet i kommunala 
politiska organ är därför att undersöka uppfyllandet av de centrala egenskaperna i deltagardemokratin.

Vad som däremot inte kommer att analyseras är andra möjliga former för att påverka kommunalpolitiken. Eftersom denna undersökning är avgränsad till den formella kommunala demokratin behandlar analyserna enbart kommunala förtroendeuppdrag medan annat politiskt deltagande lämnas därhän. Detta innebär inte att alternativa former för att påverka är oviktiga för folkligt deltagande, utan är endast en följd av att undersökningens strålkastarljus är riktat mot deltagande inom den lokala representativa demokratin.

Under 1990-talet försämrades möjligheterna för medborgarna att delta i den svenska lokala representativa demokratin. Mellan 1989 och 1999 minskade antalet kommunala förtroendeuppdrag med 15000 uppdrag, från 83500 uppdrag till 68 500 uppdrag (Hagevi 2000:39-40). Forskare har betonat att krav på ökad effektivitet kan krocka med förmågan att fatta folkligt förankrade beslut (se t.ex. Oscarsson 1999:7-10). Detta blir tydligt när effektivitet direkt relateras till en mer slimmad politisk organisation i kommunerna. Ett minskat antal kommunalpolitiska uppdrag minskar möjligheten för medborgarna att delta $\mathrm{i}$ kommunala organ. De förtroendevalda riskerar då att bli färre och det politiska deltagandet minskar i den lokala representativa demokratin. Under 1990-talet minskade antalet lokala politiker - kommunalpolitiker - med 10000 personer, vilket sedan dess följts av en ytterligare minskning av antalet lokalpolitiker (Hagevi 2000:41-42; Järnberg \& Olofsson 2011:12). Som redan nämnts avser denna studie att analysera i vad mån 1990-talets lokalpolitiker önskade en sådan utveckling som då initierades.

\section{Ett väljarinriktat ideal konkurrerar}

Deltagaridealet har inte monopol som demokratiskt ideal. Det finns alternativa ideal som kan uppfattas som minst lika demokratiska. Ett sådant är det väljarinriktade idealet (Hagevi 2000: 78-79; Gilljam \& Jodal 2002; Gilljam m.fl. 2010: 39-42; Esaiasson m.fl. 2011; Karlsson \& Gilljam 2014:74-79). Ett väljarinriktat ideal accentuerar att medborgarnas vilja ska kanaliseras genom valen. De direktvalda politikerna i kommunfullmäktige och dess "regering" kommunstyrelsen ska inför väljarna vara ansvariga för hela den kommunala 
verksamheten. Det väljarinriktade idealet kontrasterar mot deltagaridealet då detta i större utsträckning betonar deltagande i olika organ mellan valen. Ett på många deltagare spritt inflytande anses vara viktigare än tydligt ansvar inför väljarna (se Petersson 1987; Gilljam \& Möller 1996; Jarl 1999; Holmberg 1999; Amnå 1999; jfr Schumpeter 2008). ${ }^{3}$

I några undersökningar pekar slutsatserna på att den svenska demokratin utvecklas i riktning mot det väljarinriktade idealet och bort från deltagaridealet (Gilljam \& Möller 1996; Petersson m.fl. 1998:129-131; Amnå 1999; Esaiasson m.fl. 2011:271). Några av de argumenten för ett minskat antal nämnder och kommunalpolitiker har också klara likheter med det väljarinriktade idealet. Ett sådant argument är att ett minskat antal nämnder ökar möjligheterna till politisk styrning och gör verksamheten mer överskådlig. Ofta kombineras detta argument med åsikten att det i de olika nämnderna ändå enbart finns förkämpar för den egna verksamheten som inte är intresserade av att ta hänsyn till det allmänna bästa (se t.ex. Montin 1996; Göteborgs-Posten 6/9 1997). Det är enligt detta synsätt bättre att koncentrera makten till kommunstyrelsen där politiker med ansvar för hela den kommunala verksamheten kan väga in alla för- och nackdelar när de fattar beslut. En sådan politisk organisation är mer orienterad mot väljarnas preferenser.

Kan det ha varit så att de lokala politikerna under 1990-talet hade övergivet deltagaridealet till förmån för ett väljarinriktat ideal och att detta underlättade den kraftiga minskningen av antalet kommunala förtroendeuppdrag? Det var ju först och främst de lokala politikerna själva som danade institutionerna i den lokala representativa demokratin.

Somliga forskare har fört fram effektivitet som ett demokratiskt ideal (Rothstein 1995: 16-17, 101-121, 130-131). Konkret handlar kraven på ökad effektivitet ofta om att minska antalet politiker och att de politiker som finns kvar ska fatta beslut inom ett mer begränsat område (se t.ex. Rapp 2011). Kraven på färre politiker har haft störst effekt på lokal nivå i kommunerna, i alla fall sett till antalet avskaffade politiska uppdrag. Det är också värt att notera att effektivitetskraven mycket väl kan kombineras med det väljarinriktade idealet: ett starkare fokus på blott folkvalda politiker anses då öka demokratin och leda till en effektivare styrning av kommunerna (Esaiasson m.fl. 2011).

$10 \quad 2015: 2 \mathrm{nr} 1-2 \mid$ SurveyJournalen 
Vid sidan av alternativa demokratiideal och krav på effektivitet angavs även andra skäl till att ifrågasätta deltagaridealet på 1990-talet. Somliga menade att den offentliga sektorns tillväxt hade gjort att fritidspolitikern ersatts av professionella politiker som styrde och kontrollerade kommunens tjänstemän (Hagevi 2000). Andra rapporterade ett minskat intresse för att axla manteln som förtroendevald (se t.ex. Kommunaktuellt 1997-06-05). Dessa och andra faktorer kunde också ligga bakom ett ifrågasättande av deltagaridealet. Istället för att vara ett ideal som var vägledande vid utformandet av den lokala representativa demokratin på 1990talet, kanske det blott hörde hemma vid högtidstalen eller inte ens där. När det kom till kritan var kanske stödet för deltagaridealet urgröpt redan bland 1990talets lokalpolitiker.

\section{Frågeställningar om lokala politikers demokratiideal}

Vilka ideal tyckte 1990-talets lokala politiker skulle prägla de lokala demokratiska institutionerna? Frågan är speciellt intressant då det var dessa politiker som till stor del beslutade om nedskärningen av den politiska organisationen i kommunerna. En första fråga att analysera är de lokala politikernas attityd till deltagaridealet och det väljarinriktade idealet under 1990-talet. Hur starkt var stödet för deltagaridealet och för det väljarinriktade idealet bland de lokala politikerna under 1990-talet? Frågan berör attityder till deltagande, effektivitet, konflikt och samarbete, maktfördelning. I den empiriska undersökningen är jag även öppen för alternativa uppfattningar av idealen. Det kan nämligen vara så att 1990-talets lokala politiker - till skillnad från forskarna - inte såg de två idealen som varandras motsatser, utan att de ansåg att idealen gick att förena. Låt oss därför också ta reda på i vad mån de lokala politikerna uppfattade de två demokratiska ideal som analyseras i denna undersökning som motstridiga.

Enligt regeringsformens portalparagraf utgår all offentlig makt från folket och förverkligas genom representativt och parlamentariskt statsskick och genom kommunal självstyrelse. En sådan representativ demokrati måste uppfattas som legitim inför väljarna. Legitimitetsproblemet är tvåfaldigt. Dels berör det förtroendet för de demokratiska institutionerna. Dels berör det förtroendet för de demokratiska institutionernas företrädare: de folkvalda politikerna. Precis som idag var det inte alla som uppfattade att omgivningen hade respekt för politiker på 1990-talet. De menade att ett utbrett politikermisstroende gjorde det mindre 
lockande att axla manteln som förtroendevald. Detta ledde till att det var svårt att fylla alla kommunala uppdrag, varför de avskaffades. En del menade också att värdeförändringar innebar att stora väljargrupper ställde frågan: varför ska det finnas så många politiker (Gilljam \& Jodal 2002)?

Den andra frågan - eller rättare sagt frågekategorin - fokuserar således på förtroendet för politikerna. Ökade eller minskade väljarnas förtroende för politikerna på 1990-talet? Vilken uppfattning hade dåtidens lokala politiker om utvecklingen av politikerförtroende bland väljarna? Vad trodde de lokala politikerna låg bakom ett sviktande förtroende för politiker?

\section{Frågeställningar om politikernas individuella deltagande}

Att vara kommunalt förtroendevald är en form av politiskt deltagande som sker inom den lokala representativa demokratin. Det politiska deltagandet inom den lokala representativa demokratin är tämligen formell. Det rör sig om offentliga organ: kommunfullmäktige, kommunstyrelse och övriga kommunala nämnder. Som kommunal nämnd räknas de organ som helt och hållet är valda av kommunfullmäktige, innehåller fler än en ledamot och inte drivs som bolag eller stiftelse.

Som kommunalt förtroendevald finns det också olika typer av deltagande. Att vara ordförande i en nämnd är något annat än att vara suppleant. Somliga har många kommunala uppdrag, andra bara ett. En del har lång erfarenhet som lokal politiker, andra har precis börjat.

Det går förvisso att ha högt ställda ideal om deltagande inom den lokala representativa demokratin. Men den politiker som år ut och år in sett att lokalpolitiken inte lever upp till deltagaridealet kan bli desillusionerad. En viktig fråga är då hur väl 1990-talets lokalpolitiker själva levde upp till deltagaridealets högt ställda mål om att leverera demokrati och lika inflytande. Ett deltagande i den lokala representativa demokratin kan till exempel ske i olika stor omfattning. Trots alla demokratiska ideal om likhet mellan deltagarna riskerar det finnas kvalitativa olikheter i de lokala politikernas deltagande och inte bara mellan de som har och de som inte har ett kommunalt uppdrag.

Ett av deltagaridealet mål rör demokratins kärna: lika inflytande. Enligt deltagaridealet ska alla oavsett social bakgrund ha lika möjligheter att delta i den 
lokala representativa demokratin. Vilka egenskaper människor har som ägnar sig åt olika typer av deltagande kan då visa i vad mån inflytandet skiftar mellan olika befolkningsgrupper. En del grupper kan vara underrepresenterade, det vill säga ha en lägre andel deltagare än vad deras andel av valmanskåren är. Andra kan vara överrepresenterade, det vill säga ha en högre andel deltagare än vad deras andel i valmanskåren är. Dessutom ger olika typer av deltagande olika mycket inflytande. Exempel på olika typer av deltagande som ger skillnader $\mathrm{i}$ inflytande är innehav av ordförandeposten, eller skillnaden mellan att vara ordinarie ledamot och suppleant. Det är möjligt att en viss typ av deltagande som är relaterat till ganska stort inflytande är tämligen svårtillgängligt. Även vilka medborgare som kan utnyttja den typ av deltagande som innebär kontakter mellan väljare och valda är väsentligt att analysera. En anledning till varför anhängarna av deltagaridealet förespråkar många förtroendevalda är att dessa ska fungera som kanaler ut $\mathrm{i}$ samhället. Men när detta inte fungerar är det en av de saker som kan göra att politiker blir desillusionerade. En viktig fråga är då hur väl 1990-talets lokalpolitiker själva levde upp till deltagaridealets högt ställda mål om att leverera demokrati och lika inflytande. Nästa frågeställning beaktar därför vem som var lokalpolitiker och vem som innehade olika uppdrag i slutet av 1990-talet. Vilka var det som innehade olika uppdrag $i$ den lokala representativa demokratin på 1990-talet?

Politiskt deltagande kan ske inom olika politiska sakområden. Med politiskt sakområde menas här de ämnen som den politiska aktiviteten avser att påverka. Olika samhällsgruppers deltagande kan skifta beroende på sakområde. Också på 1990-talet fanns risken att vissa samhällsgrupper var underrepresenterade inom olika sakområden medan andra var överrepresenterade. Fanns det skillnader $i$ olika samhällsgruppers deltagande inom olika sakområden $i$ den lokala representativa demokratin på 1990-talet?

Politiskt deltagande är inte bara att inneha ett uppdrag. Det finns även kvalitativa aspekter på det politiska deltagandet, inte bara formella. Deltagandets kvalitet berör individens uppfattning av deltagandets nytta, måluppfyllelse, tillfredsställelse samt grad av aktivitet under och omsorg över deltagandet. Kvalitativt deltagande syftar på graden av aktivitet och inflytande, inte bara närvaro eller innehav. En uppdragsinnehavare kan i olika stor utsträckning själv vara aktiv vid beslut, till exempel genom att yttra sig. En del lägger ner mycket tid 
på politiken, andra mindre. Somliga uppfattar sig ha stort inflytande genom sitt deltagande, andra upplever sig ha relativt lite att säga till om. Vilka var skillnaderna mellan olika samhällsgrupper $i$ kvalitativt deltagande $i$ den lokala representativa demokratin på 1990-talet?

\section{Frågeställningar om framtida demokratiska reformer}

Till sist beger vi oss tillbaka till framtiden. Detta sker genom att studera vilka önskemål som 1990-talets lokala politiker hade inför framtiden. Till viss del är det därmed möjligt att jämföra den utveckling som 1990-talets lokalpolitiker önskade sig med vad som faktiskt har skett. Vilka konkreta demokratiska reformer ville 1990-talets lokalpolitiker se i framtiden? Sådana önskemål ska inte ses som likvärdiga barns önskelistor till jultomten. Till stor del var det de lokala politikerna själva som bestämde över hur de egna framtida lokala institutionerna skulle utformas. Det är därför av stort intresse att analysera 1990-talets lokalpolitikers egna synpunkter om vad de borde ha gjort.

Ytterligare en aspekt på det politiska livet är i vad mån frågorna var uppsatta på den politiska dagordningen på 1990-talet och om denna dagordning genererade partipolitiska konfliktlinjer. Var frågorna om lokala demokratiska reformer partipolitiserade på 1990-talet, det vill säga skilde sig de lokala politikernas åsikter åt beroende på vilket parti de representerade?

Återigen är det av intresse att koppla de lokala politikernas framtidsvisioner till deltagaridealet och det väljarinriktade idealet. De olika reformförslagen kan i olika stor utsträckning vara kopplade till det ena eller det andra demokratiidealet. Rimligtvis borde de som var anhängare av deltagaridealet vara mer intresserade av reformer som stärker detta ideal, medan de som var orienterade mot det väljarinriktade idealet istället borde efterlysa reformer som underlättar detta ideal. Finns det åsiktsskillnader angående de demokratiska reformförslagen som bottnar i olika syn på deltagaridealet och det väljarinriktade idealet? Detta är den sista aspekten som analyseras i denna undersökning. 


\section{Tillvägagångssätt}

För att kunna genomföra de analyser som är nödvändiga, så ovan angivna frågeställningar kan besvaras, har jag genomfört en surveyundersökning av lokala politiker. Inte alla 44500 lokala politiker (samtliga kommunalpolitiker år 1999) har deltagit i undersökningen. Istället gjordes ett urval på 2400 lokala politiker. Avsikten var att urvalet skulle vara representativt med de lokala politikerna $\mathrm{i}$ Sverige i förhållande till kommunernas folkmängd. Urvalet var således inte representativt med samtliga kommunalt förtroendevalda i Sverige. Ett sådant urval skulle domineras av lokala politiker från små kommuner, medan lokala politiker som representerade mer än halva Sveriges befolkning skulle vara i klar minoritet. För att motverka ett sådant urval hade enheterna $i$ urvalsramen viktats för att representera de lokala politikerna i förhållande till kommunernas folkmängd. Det innebar till exempel att partifördelningen i urvalet inte liknade partifördelningen bland de kommunalt förtroendevalda. Istället liknade partifördelningen i urvalet partifördelningen bland de röstande i 1998 års kommunalval. Själva urvalsprocessen baserades på ett efter befolkningsmängd viktat slumpmässigt urval av 97 politiska organ av totalt 3044 kommunfullmäktige, kommunstyrelser och kommunala nämnder. Samtliga ordinarie ledamöter (inga suppleanter) i de framlottade politiska organen ingick i urvalet. Fältarbetet påbörjades i början av oktober och avslutades i början av december år 1999. Andelen svarande bland de lokala politikerna var 75 procent. Med tanke på den korta tid som stod till förfogande för fältarbete (två månader) får bortfallet anses vara inom gängse ramar, samtidigt som mindre skillnader i resultatredovisningen ska tolkas med försiktighet.

I denna studie jämförs de lokala politikerna med förhållanden i valmanskåren. Uppgifterna om väljarna hämtades framförallt från SOM-institutet vid Göteborgs universitet som årligen genomförde surveyundersökningar av ett representativt urval av den svenska befolkningen mellan 18-80 år. Den aktuella surveyundersökningen som användes i de följande analyserna var från år 1998. ${ }^{4}$ Sammansättningen i de kommunfullmäktige, kommunstyrelser och nämnder som valts ut att ingå i denna undersökning baseras på det kommunalval som hölls detta år. Dessa uppgifter kompletteras med data som Statistiska centralbyrån (SCB) presenterat i olika rapporter. 


\section{De lokala politikernas demokratiska ideal}

Den första empiriska uppgiften är att undersöka vilka demokratiska ideal de lokala politikerna hade i slutet av 1990-talet. Är någon riktigt kritisk är det möjligt att påstå att demokratiidealet och det väljarinriktade idealet endast är skrivbordskonstruktioner, föga förankrade i verkligheten. Det går således inte an att bara fråga i vilken mån de lokala politikerna stödjer medborgerligt deltagande och i vilka former. Då finns risken att andra ideal än deltagaridealet redan på förhand har definierats bort. Även ståndpunkter som är förankrade i ett väljarinriktat ideal måste undersökas. Dessutom bör också andra ställningstaganden om den lokala demokratin ventileras även om dessa i teoretisk mening inte hör samman med deltagaridealet eller det väljarinriktade idealet. Anledningen till detta är att undersökningarna kan visa att respektive demokratiideal även empiriskt kan kopplas till andra ställningstaganden om demokrati.

Men till att börja med kommer jag att undersöka om de lokala politikerna var nöjda med hur demokratin fungerade. Om de lokala politikerna tenderade att vara nöjda borde förändringslustan ha varit liten. Om de däremot tenderade att vara missnöjda borde viljan till reformer ha varit starkare.

\section{Problem i demokratin}

Låt oss börja med en rent deskriptiv fråga: vad tyckte 1990-talets lokala politiker om demokratin? Var de nöjda med på vilket sätt den fungerade? Frågan gällde dels demokratin i de svarandes egen hemkommun och dels på riksnivå i hela Sverige. Mer precist besvarade de lokala politikerna frågan "På hela taget, hur nöjd är Du med det sätt på vilket demokratin fungerar i Din kommun och på riksnivå?" Därefter nämndes "i din kommun" och "på riksnivå". I båda fallen kunde de markera "mycket nöjd", "ganska nöjd", "inte särskilt nöjd" och "inte alls nöjd". Resultatet presenteras i tabell 1. Där redovisas även opinionsbalansen (ob). I detta fall beräknades opinionsbalansen som följer. Andelen som svarade inte alls nöjd eller inte särskilt nöjd subtraheras från de som svarade mycket nöjd eller ganska nöjd. Opinionsbalansen kan ha varierat mellan +100 (samtliga svarande var mycket eller ganska nöjda med demokratin) och -100 (samtliga svarande var 
inte särskilt eller inte alls nöjda med demokratin). Om opinionsbalansen var 0 innebar det att andelen svarande som var nöjda var i stort sett lika stor som andelen missnöjda.

Tabell 1 Hur nöjd de lokala politikerna var med hur demokratin fungerade i den egna kommunen och på riksnivå 1999 (procent och opinionsbalans).

\begin{tabular}{lccccccc}
\hline & \multicolumn{1}{c}{$\begin{array}{c}\text { Inte } \\
\text { Mycket } \\
\text { nöjd }\end{array}$} & $\begin{array}{c}\text { Ganska } \\
\text { nöjd }\end{array}$ & $\begin{array}{c}\text { särskilt } \\
\text { nöjd }\end{array}$ & $\begin{array}{c}\text { Inte alls } \\
\text { nöjd }\end{array}$ & $\begin{array}{c}\text { Summa } \\
\text { procent }\end{array}$ & $\begin{array}{c}\text { Antal } \\
\text { svarande }\end{array}$ & $\begin{array}{c}\text { Opinions- } \\
\text { balans }\end{array}$ \\
\hline I den egna kommunen & 11 & 53 & 28 & 8 & 100 & 1757 & +28 \\
På riksnivå & 3 & 41 & 43 & 13 & 100 & 1737 & -12 \\
\hline
\end{tabular}

Kommentar: Opinionsbalansen beräknas genom att subtrahera procentandelen inte särskild nöjd eller inte alls nöjd från procentandelen mycket nöjd eller ganska nöjd.

År 1999 var de lokala politikerna nöjdare med hur demokratin fungerade i den egna kommunen än vad som var fallet på riksnivå. Nästan två tredjedelar förklarade sig vara mycket nöjd eller ganska nöjd med hur demokratin fungerade $i$ den egna kommunen $(\mathrm{ob}=+28)$. Däremot förklarade de flesta att de inte var särskilt eller inte alls nöjda med hur demokratin fungerade på riksnivå (ob=-12). De lokala politikerna visade sig således vara mycket kritiska till hur demokratin fungerade på riksnivå i 1990-talets Sverige.

Svaren från de lokala politikerna kan jämföras med svaren från tidigare nämnda surveyundersökning av SOM-institutet 1998. Frågan som ställdes till ett representativt urval av den svenska befolkningen mellan 18-80 år löd: "På det hela taget, hur nöjd är du med det sätt på vilket demokratin fungerar i Sverige?" De svarande kunde således inte skilja mellan förhållandena i den egna kommunen och på riksnivå. Antagligen innebar detta att de flesta av de svarande i SOMinstitutets undersökning i huvudsak reflekterade över hur demokratin fungerade på riksnivå. Svaren ger oss ändå en jämförelsepunkt med de lokala politikernas uppfattning. Den svenska befolkningen tenderade att vara positiv till hur den svenska demokratin fungerade. Av de svarande var 62 procent mycket eller ganska nöjda med hur demokratin fungerade, medan 38 procent svarade inte särskilt eller inte alls nöjda $(n=3497, \quad o b=+24)$. I tabell 2 redovisas opinionsbalansen för de lokala politikerna efter parti. 
Tabell 2 Hur nöjd de lokala politikerna var med hur demokratin fungerade i den egna kommunen och på riksnivå, efter parti 1999 (opinionsbalans).

\begin{tabular}{lcccccccc}
\hline & \multicolumn{10}{c}{ Parti } \\
\cline { 2 - 9 } & $v$ & $s$ & $m p$ & $c$ & $f p$ & $k d$ & $m$ & övriga \\
\hline I den egna kommunen & +2 & +33 & -31 & +43 & +19 & +35 & +42 & -30 \\
På riksnivå & -10 & +7 & -24 & -23 & -14 & +2 & -32 & -68 \\
\hline
\end{tabular}

Kommentar: Opinionsbalansen beräknas genom att subtrahera procentandelen inte särskild nöjd eller inte alls nöjd från procentandelen mycket eller ganska nöjd.

Mellan partierna fanns det stora skillnader i hur nöjda lokalpolitikerna var med hur demokratin fungerar. Till viss del berodde sannolikt partiernas skiftande svar på vem som innehade den politiska makten. Lokalpolitikerna i de partier som var $\mathrm{i}$ majoritet och hade ansvar för kommunstyret tenderade att vara nöjdare med hur demokratin fungerade än lokalpolitikerna i de partier som var i minoritet. På kommunalnivå var centerpartisterna mest nöjda med hur demokratin fungerade $(o b=+43)$. I särklass mest missnöjda var miljöpartisterna (ob=-31). På riksnivå var socialdemokraterna de enda som tenderade att vara mer nöjda än missnöjda med hur demokratins fungerade $(\mathrm{ob}=+7)$. Mest missnöjda med hur demokratin fungerade på riksnivå var moderaterna $(\mathrm{ob}=-32)$.

De lokala politikernas kritiska inställning till hur demokratin fungerade födde en fråga om vad de var kritiska till. Denna undersökning fokuserade på förhållandena på den lokala nivån. Vilka demokratiska problem såg de lokala politikerna $\mathrm{i}$ den egna kommunen? Enligt deltagaridealet riskerade demokratins problem att öka om för få väljare hade erfarenhet av att ha varit förtroendevald. Förståelse för samhällsproblem och politikens villkor riskerade att bli begränsade till en liten grupp. Ett vanligt demokratiskt problem som sades ligga anhängarna av det väljarinriktade idealet nära om hjärtat var att väljarna var politiskt okunniga. Nationalekonomen Joseph Schumpeter (2008) - en välkänd anhängare av ett elitistiskt väljarinriktat ideal - påstod till exempel att väljarna var "påfallande ofta ointelligenta, trångsynta och egoistiska." En variant av åsikten om okunniga väljare var att väljarna endast var intresserade av rikspolitik, medan de inte bryr sig om kommunalpolitik. De lokala politikerna kunde även ha uppfattat brister i den kommunala självstyrelsen som ett demokratiskt problem: folkviljan i kommunen förhindrades av beslut i riksdag och regering. De lokala politikerna 
borde i så fall ha ansett att riksdag och regering lade sig i kommunens verksamhet för mycket. Denna åsikt var dock varken kopplad till deltagaridealet eller det väljarinriktade idealet. I tabell 3 presenteras de lokala politikernas ställningstaganden till fyra påståenden om den lokala demokratin i den egna kommunen. Det påstående som är knutet till deltagaridealet är markerat med ett kommunalhus (䍏) medan de påståenden som har sagts ha beröring med det väljarinriktade idealet är markerade med en valurna ( $)$. För svarspersonerna var det möjligt att besvara varje påstående med "Instämmer helt", "Instämmer i stort sett", "Delvis motsatt åsikt" och "Helt motsatt åsikt". Även nu redovisas opinionsbalansen (ob). I detta fall beräknades opinionsbalansen som följer. Andelen som svarade delvis motstatt åsikt eller helt motsatt åsikt subtraherades från de som svarade instämmer helt eller instämmer i stort sett. Opinionsbalansen kunde ha varierat mellan +100 (samtliga svarande instämde helt eller i stort sett med påståendet) och -100 (samtliga svarande hade helt eller delvis motsatt åsikt). Om opinionsbalansen var 0 innebär det att andelen svarande som instämde helt eller i stort sett var lika många som de som hade helt eller delvis motsatt åsikt.

Tabell 3 De lokala politikernas ställningstaganden till fyra påståenden om den demokratin i den egna kommunen 1999 (procent och opinionsbalans).

\begin{tabular}{lccccccc}
\hline & $\begin{array}{c}\text { Instämmer } \\
\text { helt }\end{array}$ & $\begin{array}{l}\text { Instämmer } \\
\text { stort sett }\end{array}$ & $\begin{array}{c}\text { Delvis } \\
\text { motsatt åsikt }\end{array}$ & $\begin{array}{c}\text { Helt motsatt } \\
\text { asikt }\end{array}$ & $\begin{array}{c}\text { Summa } \\
\text { procent }\end{array}$ & $\begin{array}{c}\text { Antal } \\
\text { svarande }\end{array}$ & $\begin{array}{c}\text { Opinions- } \\
\text { balans }\end{array}$ \\
\hline $\begin{array}{l}\text { 衁För få väljare har erfarenhet av att } \\
\text { ha varit förtroendevalda }\end{array}$ & 58 & 37 & 4 & 1 & 100 & 1751 & +90 \\
$\begin{array}{l}\text { \&Väljarnas kunskap om } \\
\text { kommunalpolitik är dålig }\end{array}$ & 35 & 50 & 14 & 1 & 100 & 1752 & +70 \\
$\begin{array}{l}\text { +Väljarna bryr sig bara om } \\
\text { rikspolitik, inte kommunalpolitik }\end{array}$ & 3 & 31 & 51 & 15 & 100 & 1748 & -32 \\
$\begin{array}{l}\text { Riksdag och regering lägger sig } i \\
\text { kommunens verksamhet för mycket }\end{array}$ & 26 & 35 & 34 & 5 & 100 & 1736 & +22 \\
\hline
\end{tabular}

Kommentar: Opinionsbalansen beräknas genom att subtrahera procentandelen som har delvis eller helt motsatt åsikt från procentandelen som instämmer helt eller i stort sett.

De lokala politikerna såg demokratiska problem i den egna kommunen som både kunde sättas i samband med deltagaridealet och det väljarinriktade idealet. Påståendet att för få väljare hade erfarenhet av att 
ha varit förtroendevalda fick flest instämmanden bland de lokala politikerna, något som var associerat med deltagaridealet (ob=+90). Däremot uppfattade inte lokalpolitikerna väljarna som kunniga. En oväntad stor majoritet instämde nämligen med åsikten att väljarnas kunskap om kommunalpolitik var dålig $(\mathrm{ob}=+70)$. Denna skepsis över medborgarnas kunskap kunde kopplas till en positiv attityd till en mer representativ, för att inte säga elitistisk, demokratisyn (Dahl 1989). Däremot hade de flesta lokala politiker en motsatt åsikt till påståendet att väljarna bara brydde sig om rikspolitik, inte kommunalpolitik (ob=-32). Dessutom rådde det delade meningar om riksdag och regering lade sig $\mathrm{i}$ kommunernas verksamhet för mycket, även om de lokala politikerna tenderade att instämma i påståendet $(\mathrm{ob}=+22)$. De delade meningarna om ställningen för den kommunala självstyrelsen indikerade ganska stora skillnader mellan partierna. I tabell 4 redovisas en sammanställning över opinionsbalansen för de fyra påståendena inom respektive parti.

Tabell 4 De lokala politikernas ställningstaganden till fyra påståenden om demokratin i den egna kommunen, efter parti 1999 (opinionsbalans).

\begin{tabular}{|c|c|c|c|c|c|c|c|c|}
\hline & \multicolumn{8}{|c|}{ Parti } \\
\hline & $v$ & $S$ & $m p$ & $c$ & $f p$ & $k d$ & $m$ & övriga \\
\hline $\begin{array}{l}\text { 亚För få väljare har erfarenhet av } \\
\text { att ha varit förtroendevalda }\end{array}$ & +90 & +94 & +96 & +97 & +98 & +80 & +86 & +90 \\
\hline $\begin{array}{l}\text { \&Väljarnas kunskap om } \\
\text { kommunalpolitik är dålig }\end{array}$ & +52 & +70 & +84 & +72 & +82 & +74 & +76 & +76 \\
\hline $\begin{array}{l}\text { \&äljarna bryr sig bara om } \\
\text { rikspolitik, inte kommunalpolitik }\end{array}$ & -54 & -32 & -22 & -32 & -20 & -32 & -30 & -18 \\
\hline $\begin{array}{l}\text { Riksdag och regering lägger sig i } \\
\text { kommunens verksamhet för } \\
\text { mycket }\end{array}$ & -16 & -16 & +4 & +26 & +52 & +52 & +76 & +44 \\
\hline
\end{tabular}

Kommentar: Opinionsbalansen beräknas genom att subtrahera procentandelen som har delvis eller helt motsatt åsikt från procentandelen som instämmer helt eller i stort sett.

Skillnaderna mellan partierna var störst vad gäller synen på den kommunala självstyrelsen: betydligt färre vänsterpartister och socialdemokrater än borgerliga 
lokala politiker instämde $\mathrm{i}$ påståendet att riksdag och regering lade sig i kommunernas verksamhet för mycket (jfr Strandberg 1998). Angående åsikten att för få väljare hade erfarenhet som förtroendevalda fanns inga nämnvärda skillnader mellan partierna. Skillnaderna mellan partierna var också mycket små vad gäller instämmandena av påståendet att väljarna har dålig kunskap om kommunalpolitik, med ett visst undantag för vänsterpartisterna som instämde $i$ något mindre utsträckning än andra lokala politiker.

\section{Demokratiideal}

För att undersöka de demokratiska idealen bland 1990-talets lokala politiker presenterades ett batteri med påståendefrågor till de lokala politikerna. Påståendefrågorna avsåg att mäta de lokala politikernas uppfattning om de verkliga förhållandena; hur det var, inte hur det borde vara. Påståendefrågor fungerade på så sätt att de lokala politikerna ställdes inför en rad påståenden om kommunal demokrati. De tog ställning genom att ange om de "Instämde helt, "Instämde i stor sett" eller om de hade "Delvis motsatt åsikt" eller "Helt motsatt åsikt". De lokala politikerna hade också möjligt att ange "Ingen åsikt, vet ej”.

De påståenden som avsåg att undersöka de lokala politikernas demokratiideal var fem till antalet: "Att ha många kommunalt förtroendevalda är bra för demokratin", "Många kommunala nämnder riskerar att minska överskådligheten och försvaga demokratin", "Färre kommunalt förtroendevalda leder till effektivare politiskt styrning av kommunens verksamhet", "Verksamheten blir effektivare ju mindre politikerna lägger sig i besluten" och "Nämndledamöter uppfattar sig ofta som företrädare för en kommunal verksamhetssektor snarare än som företrädare för allmänintresset". Det första påståendet betraktades som ett stöd för deltagaridealet, medan de övriga påståenden var stöd för ett väljarinriktat ideal.

Två av de påståenden som båda kunde sägas höra samman med deltagaridealet och det väljarinriktade idealet var utpräglat positiva till den kommunala demokratin: "Genom att rösta i kommunalvalen är man i hög grad med och bestämmer hur kommunalpolitiken utformas" och "En överflyttning av ansvaret från stat till kommun ger medborgarna bättre inflytande över den offentliga servicen." 
Tabell 5 De lokala politikernas ställningstaganden till 13 påståenden om demokratin i kommunen 1999 (procent).

\begin{tabular}{|c|c|c|c|c|c|c|c|c|}
\hline & $\begin{array}{l}\text { Instäm- } \\
\text { mer helt }\end{array}$ & $\begin{array}{c}\text { Instäm- } \\
\text { mer i stort } \\
\text { sett } \\
\end{array}$ & $\begin{array}{l}\text { Delvis } \\
\text { motsatt } \\
\text { asikt } \\
\end{array}$ & $\begin{array}{c}\text { Helt } \\
\text { motsatt } \\
\text { åsikt } \\
\end{array}$ & $\begin{array}{l}\text { Ingen } \\
\text { åsikt } \\
\text { vet ej }\end{array}$ & $\begin{array}{l}\text { Summa } \\
\text { procent }\end{array}$ & $\begin{array}{c}\text { Antal } \\
\text { svarande }\end{array}$ & $\begin{array}{c}\text { Opinions- } \\
\text { balans }\end{array}$ \\
\hline $\begin{array}{l}\text { Genom att rösta är man } \\
\text { med och bestämmer }\end{array}$ & 29 & 55 & 13 & 2 & 0 & 100 & 1677 & +69 \\
\hline $\begin{array}{l}\text { 亚Många förtroendevalda } \\
\text { är bra för demokratin }\end{array}$ & 34 & 42 & 17 & 6 & 2 & 100 & 1671 & +53 \\
\hline $\begin{array}{l}\text { Kommunalisering ökar } \\
\text { medborgarnas inflytande }\end{array}$ & 21 & 51 & 18 & 5 & 4 & 100 & 1670 & +49 \\
\hline $\begin{array}{l}\text { Makten är koncentrerad } \\
\text { till ett fåtal i toppen }\end{array}$ & 20 & 49 & 24 & 6 & 1 & 100 & 1673 & +39 \\
\hline $\begin{array}{l}\text { Nämndledamöter före- } \\
\text { träder verksamhets- } \\
\text { sektorn, inte väljarna }\end{array}$ & 8 & 38 & 33 & 16 & 4 & 100 & 1668 & -3 \\
\hline $\begin{array}{l}\text { Politiker granskar bara } \\
\text { tjänstemännens förslag } \\
\text { \&Många nämnder }\end{array}$ & 8 & 35 & 37 & 19 & 1 & 100 & 1672 & -13 \\
\hline $\begin{array}{l}\text { minskar över- } \\
\text { skådligheten }\end{array}$ & 6 & 22 & 35 & 30 & 7 & 100 & 1665 & -37 \\
\hline $\begin{array}{l}\text { Färre förtroendevalda } \\
\text { ger effektivare styre av } \\
\text { verksamheten }\end{array}$ & 5 & 24 & 33 & 36 & 3 & 100 & 1664 & -40 \\
\hline $\begin{array}{l}\text { Kommunens framtid } \\
\text { avgörs på andra håll }\end{array}$ & 1 & 22 & 50 & 26 & 1 & 100 & 1671 & -53 \\
\hline $\begin{array}{l}\text { Politikerna söker konflikt } \\
\text { om småsaker }\end{array}$ & 4 & 18 & 39 & 36 & 3 & 100 & 1670 & -53 \\
\hline $\begin{array}{l}\text { Politikerna är alltför } \\
\text { angelägna att komma } \\
\text { överens }\end{array}$ & 2 & 20 & 51 & 25 & 1 & 100 & 1674 & -54 \\
\hline $\begin{array}{l}\text { Verksamheten är effek- } \\
\text { tivare om politikerna inte } \\
\text { lägger sig i besluten }\end{array}$ & 3 & 12 & 33 & 50 & 2 & 100 & 1668 & -68 \\
\hline $\begin{array}{l}\text { Det spelar ingen roll vilket } \\
\text { parti som har makten }\end{array}$ & 1 & 5 & 19 & 75 & 0 & 100 & 1678 & -88 \\
\hline
\end{tabular}

Kommentar: Opinionsbalansen beräknas genom att subtrahera procentandelen som har delvis eller helt motsatt åsikt från procentandelen som instämmer helt eller i stort sett.

Andra påståenden var mer negativa: "Det spelar ingen roll för kommunalpolitiken vilka partier som har makten i kommunen", "Makten i kommunen finns koncentrerad till ett fătal i toppen", "Det betyder ingenting var politikerna i kommunen bestämmer, det är beslut på andra håll som avgör kommunens framtid", "Politikerna i kommunen är alltför angelägna om att komma överens", 
"Politikerna i kommunen söker konflikt även för småsaker" och "Politikernas roll i beslutsfattandet begränsas oftast till att granska tjänstemännens förslag." Inte heller dessa ansågs ha någon speciell koppling till något av de båda demokratiidealen.

Låt oss först studera stödet från de lokala politikerna för vart och ett av de olika påståendena. Kommentarerna av tabell 5 koncentreras till opinionsbalansen. I det nu aktuella fallet beräknas opinionsbalansen genom att subtrahera procentandelen som hade delvis eller helt motsatt åsikt från procentandelen som instämde helt eller i stort sett. I tabell 5 redovisas de lokala politikernas ställningstaganden till dessa påståenden. De påståenden som var ställda med avsikt att mäta inställningen till deltagaridealet är markerade med ett kommunalhus (䍏) och de påstående som avsåg att mäta det väljarinriktade idealet är markerade med en valurna (\$).

De fyra påståenden som fick starkast stöd av de lokala politikerna berörde medborgarinflytandet, deltagaridealet och kommunal maktkoncentration. Resultatet var ett uttryck för de lokala politikernas tilltro till den lokala demokratins förmåga att representera väljarna: de som röstade hade inflytande och kommunalisering ledde till ökat medborgarinflytande. Samtidigt visade resultatet även ett starkt stöd för ett av deltagaridealets fundament. De lokala politikerna ansåg nämligen att många förtroendevalda var bra för demokratin. Enligt de lokala politikerna var inte inflytandet jämlikt fördelat bland lokalpolitikerna. Istället ansåg de flesta att makten i kommunen var koncentrerad till ett fåtal i toppen.

Vid två påståenden uppvisade lokalpolitikerna klart olika uppfattningar. I båda fallen uppmärksammades den politiska situationen för nämndledamöterna. Det rådde delade meningar om de lokala politikernas möjligheter och begränsningar att verka i nämnderna och vem nämndledamöterna verkade för. Angående påståendet att nämndledamöterna uppfattade sig som företrädare för verksamhetssektorn snarare än för allmänintresset var det ungefär lika många av de lokala politikerna som instämde som redovisade motsatt åsikt. Detta påstående avsåg att indikera ett väljarinriktat ideal.

De lokala politikernas ställningstaganden var också tämligen jämnt fördelat mellan instämmande och motsatta åsikter om att politikernas roll i beslutsfattandet ofta begränsades till att granska tjänstemännens förslag. 
I övriga påståenden anmälde de flesta lokala politiker motsatta åsikter. Påståendet att det inte spelar någon roll vilket parti som hade makten i kommunen fick knappast något stöd. Flera av de påståenden som stödde det väljarinriktade idealet fick svagt stöd. Påståendet att verksamheten blev effektivare ju mindre politikerna lade sig i besluten resulterade i flest motsatta åsikter bland de lokala politikerna. Men inte heller påståenden att många nämnder minskade överskådligheten eller att färre förtroendevalda ledde till effektivare styre av verksamheten fick något omfattande stöd. Det bör dock noteras att ungefär en fjärdedel av de lokala politikerna ändå instämde helt eller delvis i dessa påståenden.

Eftersom de lokala politikerna inte var eniga i sina reaktioner till de 13 påståendena om demokratin i kommunen var det möjligt att det fanns partipolitiska skillnader $\mathrm{i}$ deras åsikter. I tabell 6 redovisas därför opinionsbalansen i samtliga påstående för respektive parti.

I flera av påståendena fanns åsiktsskillnader mellan partierna. De fyra mest partiskiljande åsikterna fanns om påståenden som var kopplade till deltagaridealet och det väljarinriktade idealet. Påståendet att många kommunalt förtroendevalda var bra för demokratin (vilket stöder deltagaridealet) ledde till många instämmanden i de flesta partier, undantaget moderaterna. Bland moderaterna fanns ungefär lika många instämmanden som motsatta åsikter, vilket resulterade i en opinionsbalans nära noll $(\mathrm{ob}=+5)$. Detta kan jämföras med socialdemokraterna och folkpartisterna som starkast stödde påståendet om många förtroendevalda $(\mathrm{ob}=+72)$.

Angående påståendet att många nämnder riskerade att minska överskådligheten (vilket stödde det väljarinriktade idealet) var återigen moderaterna kluvna mitt itu $(\mathrm{ob}=0)$. I övriga partier hade en majoritet motsatt åsikt, extremast var miljöpartisterna $(\mathrm{ob}=-59)$.

Också vad gällde påståendet att verksamheten blev effektivare ju mindre politikerna lade sig i besluten fanns betydande skillnader mellan främst moderaterna och de övriga partierna. Precis som de flesta lokala politiker hade majoriteten av moderaterna motsatt åsikt, men hos moderaterna fanns en betydande minoritet som instämde ( $\mathrm{ob}=-34)$. Detta ledde till att opinionsbalansen bland moderaterna var närmare noll än bland övriga partier, framförallt i jämförelse med socialdemokraterna (ob=-90). 
Tabell 6 De lokala politikernas ställningstaganden till 13 påståenden om demokratin i kommunen 1999 (opinionsbalans).

\begin{tabular}{|c|c|c|c|c|c|c|c|c|}
\hline & \multicolumn{8}{|c|}{ Parti } \\
\hline & $v$ & $S$ & $m p$ & $c$ & $f p$ & $K d$ & $m$ & övriga \\
\hline $\begin{array}{l}\text { Genom att rösta är man } \\
\text { med och bestämmer }\end{array}$ & +69 & +71 & +51 & +70 & +77 & +69 & +70 & +30 \\
\hline 血Många förtroendevalda & & & & & & & & \\
\hline är bra för demokratin & +67 & +72 & +65 & +70 & +72 & +48 & +5 & +57 \\
\hline $\begin{array}{l}\text { Kommunalisering ökar } \\
\text { medborgarnas inflytande }\end{array}$ & +25 & +45 & +25 & +65 & +46 & +62 & +60 & +33 \\
\hline $\begin{array}{l}\text { Makten är koncentrerad } \\
\text { till ett fåtal i toppen }\end{array}$ & +43 & +24 & +63 & +37 & +36 & +42 & +50 & +59 \\
\hline $\begin{array}{l}\text { \&ämndledamöter före- } \\
\text { träder verksamhets- } \\
\text { sektorn, inte väljarna }\end{array}$ & -14 & -17 & +7 & +12 & +9 & -6 & +9 & +13 \\
\hline $\begin{array}{l}\text { Politiker granskar bara } \\
\text { tjänstemännens förslag } \\
\text { đMånga nämnder }\end{array}$ & -1 & -35 & +6 & -13 & -13 & -1 & -2 & +9 \\
\hline $\begin{array}{l}\text { minskar över- } \\
\text { skådligheten }\end{array}$ & -47 & -53 & -59 & -38 & -48 & -31 & 0 & -37 \\
\hline $\begin{array}{l}\text { Färre förtroendevalda } \\
\text { ger effektivare styre av } \\
\text { verksamheten }\end{array}$ & -62 & -68 & -45 & -37 & -42 & -28 & +15 & -55 \\
\hline $\begin{array}{l}\text { Kommunens framtid } \\
\text { avgörs på andra håll }\end{array}$ & -52 & -63 & -60 & -53 & -59 & -45 & -35 & -52 \\
\hline $\begin{array}{l}\text { Politikerna söker konflikt } \\
\text { om småsaker }\end{array}$ & -50 & -61 & -41 & -59 & -49 & -46 & -52 & -26 \\
\hline $\begin{array}{l}\text { Politikerna är alltför } \\
\text { angelägna att komma } \\
\text { överens }\end{array}$ & -51 & -59 & -42 & -58 & -56 & -69 & -46 & -39 \\
\hline $\begin{array}{l}\text { Verksamheten är effek- } \\
\text { tivare om politikerna inte } \\
\text { lägger sig i besluten }\end{array}$ & -82 & -90 & -73 & -70 & -76 & -53 & -34 & -68 \\
\hline $\begin{array}{l}\text { Det spelar ingen roll vilket } \\
\text { parti som har makten }\end{array}$ & -92 & -94 & -90 & -83 & -82 & -78 & -88 & -78 \\
\hline
\end{tabular}

Kommentar: Opinionsbalansen beräknas genom att subtrahera procentandelen som har delvis eller helt motsatt åsikt från procentandelen som instämmer helt eller i stort sett.

Det sista av de fyra mest partiskiljande påståendena hävdade att färre kommunalt förtroendevalda ledde till effektivare politisk styrning av kommunens verksamhet. En majoritet av moderaterna instämde i påståendet $(\mathrm{ob}=+15)$, vilket kan kontrasteras med socialdemokraterna som hade störst andel avvikande åsikter 
$(\mathrm{ob}=-68)$. Det bör noteras att även om majoriteten av kristdemokraterna intog åsikter som överensstämde med majoriteten av de lokala politikerna i de fyra nyss nämnda påståendena, anslöt sig en stor del av kristdemokraterna till samma ståndpunkter som majoriteten av moderaterna gjorde. Till exempel vad gäller påståendet om att färre politiker ledde till effektivare verksamhet var kristdemokraternas opinionsbalans inte överhövan negativ (ob=-28).

Ytterligare några påståenden orsakade viss oenighet mellan partierna. Centerpartisterna tycktes vara de största anhängarna till kommunalisering $(o b=+65)$, medan vänsterpartisterna och miljöpartisterna (båda ob=+25) inte lika självklart slöt upp kring påståendet att en överflyttning av ansvaret från stat till kommun gav medborgarna bättre inflytande över den offentliga servicen. Medan en stor del av miljöpartisterna instämde i påståendet att makten i kommunen var koncentrerad till ett fătal $\mathrm{i}$ toppen $(\mathrm{ob}=+63)$ var socialdemokraterna mer kluvna $(\mathrm{ob}=+24)$. Kristdemokraterna utmärkte sig med att inte alls tycka att politikerna var alltför angelägna att komma överens $(o b=-69)$. Socialdemokraterna tyckte inte att politikerna sökte konflikt om småsaker $(\mathrm{ob}=-61){ }^{6}$

Det fanns även påståenden där det rådde relativt stor enighet mellan partierna. Reaktionen på påståendet att det inte spelade någon roll för kommunalpolitiken vilka partier som hade makten i kommunen innebar att nästan alla lokala politiker oberoende av parti uppgav sig ha motsatt åsikt. Också påståendet att det inte betydde något vad politikerna i kommunen bestämde utan att det var beslut på andra håll som avgjorde kommunens framtid mötte ringa förståelse i de flesta partier, även om en viss skillnad mellan socialdemokraterna $(o b=-63)$ och moderaterna $(\mathrm{ob}=-35)$ kunde noteras.

Vid ett par påståenden var de flesta partier ganska splittrade. När de lokala politikerna skulle ta ställning till om nämndledamöterna snarare uppfattade sig som företrädare för en kommunal verksamhetssektor än för allmänintresset och om politikernas roll i beslutsfattandet oftast begränsades till att granska tjänstemännens förslag var antalet som instämmer ungefär lika många som anmälde motsatt åsikt i de olika partierna. Därför var opinionsbalansen tämligen nära noll i samtliga partier med ett undantag. Inom socialdemokraterna fanns en ganska stor majoritet som hade motsatt åsikt till påståendet att politiker bara granskade tjänstemännens förslag $(\mathrm{ob}=-35)$. 
Några av de lokala politikernas attityder till påståendena hade troligen sin utgångspunkt i ideologiska ställningstaganden, ofta kopplade till skillnaden mellan vänster och höger i politiken (Hagevi 2015:62-65). Moderater tenderade att $\mathrm{i}$ större utsträckning än andra lokala politiker stödja förslag som kunde ha uppfattats minska politikernas inflytande i samhället, medan vänsterpartister och socialdemokrater istället stödde motsatta idéer. Att flytta över ansvaret från stat till kommuner kunde ha uppfattas som decentralisering, vilket centerpartisterna brukade stödja (Rosén Sundström \& Sundström 2010:197). En orsak till att miljöpartiet bildades var kritik av maktkoncentrationen i politiken (Gahrton 1988: 118-120). Miljöpartisterna var också de som i störst utsträckning instämde i påståendet att makten i kommunen fanns koncentrerad till ett fåtal i toppen.

\section{Två levande demokratiideal}

De lokala politikerna ställdes inför fler påståenden än enbart de som kunde kopplas till ett av de två demokratiideal som stod i fokus i denna undersökning. Mångfalden i frågor om demokrati ökade möjligheten att undersöka om de lokala politikernas ställningstaganden verkligen var kopplade till dessa två demokratiideal, och inte bara var en konstruktion på forskares och opinionsbildares skrivbord. Om deltagande eller väljarinriktning var två levande alternativa demokratiideal hos de lokala politikerna på 1990-talet borde det ha funnits en underliggande åsiktsdimension som visade att de lokala politikernas ställningstagande hade sitt ursprung i något av dessa demokratiideal. Åsikter som inte var direkt kopplade till något av de båda demokratiidealen borde dock inte ha varit relaterade till en sådan demokratisk åsiktsdimension. Om 1990-talets lokalpolitiker inte uppvisade en åsiktsdimension som gick från stöd för deltagaridealet till stöd för det väljarinriktade idealet, så kunde tanken om två konkurrerande demokratiska ideal bland lokalpolitikerna ifrågasättas. Framförallt borde idén att deltagaridealet genomsyrade en stor del av den lokala demokratin komma på skam. Tankar om deltagarideal och ett väljarinriktat ideal kunde då kritiseras för att ha varit konstruktioner och idéer utan förankring i den politiska verkligheten. Istället var det helt andra tankar och idéer som låg bakom ledamöternas ställningstaganden om den ideala lokala demokratin.

Avsikten var att undersöka om det bland de lokala politikerna fanns en underliggande åsiktsdimension som berörde deltagaridealet och det väljarinriktade 
idealet och om denna åsiktsdimension kunde sägas ha utgjort en skiljelinje mellan lokala politiker med skilda demokratiideal. En åsiktsdimension för demokratiideal skulle ha funnits om de lokala politikernas attityder till olika påståenden om lokal demokrati formade konsistent sammanhållna mönster som kunde tolkas utifrån deltagaridealet och det väljarinriktade idealet (Bennulf 1994). Åsiktsdimensionen undersöktes genom faktoranalys. Syftet med metoden var att finna bakomliggande dimensioner som kan förklara svarsmönstren i flera påståenden (Kim \& Mueller 1978a, 1978b). Efter faktoranalysen tolkades resultatet och de olika dimensionerna beskrevs och gavs namn. En faktoranalys kan blottlägga flera dimensioner. En av dessa borde röra deltagaridealet och det väljarinriktade idealet, men även andra åsiktsdimensioner som rörde andra element i lokalpolitiken kunde uppkomma. Resultatet av faktoranalysen presenteras i tabell 7. I tabellen anges faktorladdningar som kan utläsas som korrelationen mellan respektive faktor och påstående. Faktorladdningar på minst 0,50 har försetts med ramar. Faktorladdningar som understiger 0,30 redovisas inte. Tanken är att dessa faktorladdningar tillsammans indikerar den underliggande dimensionens substans.

Faktoranalysen genererade fyra dimensioner. Dimensionen med högst förklarad varians (se sista raden i tabell 7) innehöll påståenden som till övervägande del berörde styrförhållanden i kommunen (tjänstemannastyre, maktkoncentration, uppfattningen om nämndledamöternas agerande och kommunens förmåga att styra). En rimlig tolkning av dimensionen var således styrförmåga. Tilläggas bör att de flesta lokala politiker enligt tabell 6 ställde sig avvisande till påståendena om brist på styrförmåga. Det bör också noteras att ett av de påståenden som avsåg att mäta demokratiidealet av de lokala politikerna uppfattades som ett påstående som hörde ihop med styrförmåga.

Dimensionen med näst högst förklarad varians samlade samtliga påståenden som avsåg att undersöka de lokala politikernas demokratiideal, undantaget påståendet om nämndledamöternas roll som sektorsföreträdare. Detta borde därför tolkas som en dimension för demokratiidealet. Därmed var det möjligt att konstatera att de lokala politikerna själva uppfattade en dimension för demokratiidealet som i huvudsak hade samband med de påståenden som konstruerades med avsikt att undersöka ledamöternas inställning till deltagaridealet och det väljarinriktade idealet. Demokratiidealet var således inte en skrivbordskonstruktion, utan i högsta grad levande i de lokala politikernas medvetande på 1990-talet. 
Tabell 7 Dimensioner i lokala politikers demokratiuppfattning 1999 (faktorladdningar).

\begin{tabular}{|c|c|c|c|c|}
\hline & \multicolumn{4}{|c|}{ Dimensioner } \\
\hline & $\begin{array}{l}\text { Styr- } \\
\text { förmåga }\end{array}$ & $\begin{array}{l}\text { Demokrati- } \\
\text { ideal }\end{array}$ & $\begin{array}{l}\text { Kommunal- } \\
\text { idealism }\end{array}$ & $\begin{array}{l}\text { Konsensus- } \\
\text { konflikt }\end{array}$ \\
\hline $\begin{array}{l}\text { Politiker granskar bara } \\
\text { tjänstemännens förslag }\end{array}$ & $+0,70$ & & & \\
\hline $\begin{array}{l}\text { Makten är koncentrerad till } \\
\text { ett fåtal i toppen }\end{array}$ & $+0,67$ & & & \\
\hline $\begin{array}{l}\text { Nämndledamöter företräder } \\
\text { verksamhetssektorn, inte } \\
\text { väljarna }\end{array}$ & $+0,61$ & & & \\
\hline $\begin{array}{l}\text { Kommunens framtid avgörs } \\
\text { på andra håll }\end{array}$ & $+0,51$ & & & \\
\hline $\begin{array}{l}\text { Färre förtroendevalda ger } \\
\text { effektivare styre av } \\
\text { verksamheten }\end{array}$ & & $+0,78$ & & \\
\hline $\begin{array}{l}\text { Verksamheten blir effektivare } \\
\text { om politikerna inte lägger } \\
\text { sig i besluten }\end{array}$ & & $+0,60$ & & \\
\hline $\begin{array}{l}\text { Många nämnder minskar } \\
\text { överskådligheten }\end{array}$ & & $+0,55$ & & \\
\hline $\begin{array}{l}\text { Många förtroendevalda är bra } \\
\text { för demokratin }\end{array}$ & & $-0,77$ & & \\
\hline $\begin{array}{l}\text { Kommunalisering ökar } \\
\text { medborgarnas inflytande }\end{array}$ & & & $+0,75$ & \\
\hline $\begin{array}{l}\text { Genom att rösta är man med } \\
\text { och bestämmer }\end{array}$ & & & $+0,70$ & \\
\hline $\begin{array}{l}\text { Politikerna är alltför } \\
\text { angelägna att komma } \\
\text { överens }\end{array}$ & $+0,37$ & & & $+0,68$ \\
\hline $\begin{array}{l}\text { Politikerna söker konflikt om } \\
\text { småsaker }\end{array}$ & $+0,45$ & & & $-0,66$ \\
\hline $\begin{array}{l}\text { Det spelar ingen roll vilket } \\
\text { parti som har makten }\end{array}$ & $+0,37$ & & & $+0,33$ \\
\hline Förklarad varians (procent) & 17 & 15 & 10 & 8 \\
\hline
\end{tabular}

Kommentar: Tabellen visar resultat från en principalkomponentanalys med varimaxroterad lösning Antalet faktorer har bestämts med hjälp av Kaisers kriterium. Faktorladdningar på minst 0,50 har försetts med ramar. Faktorladdningar som understiger 0,30 redovisas inte.

De övriga dimensionerna resulterade $\mathrm{i}$ en något lägre förklarad varians. Dessutom var båda av sekundärt intresse för denna undersökning. Men det var trots allt 
möjligt att tolka den tredje dimensionen som om den rörde kommunidealism: medborgarinflytandet ökade om mer ansvar flyttades över från stat till kommun samtidigt som röstning innebar att väljarna i hög grad var med och bestämde. Den sista dimensionen behandlade konsensus-konflikt, vilket också blivit dess namn. Ett påstående laddade inte högt på någon dimension: det spelar ingen roll vilket parti som har makten. En bärande orsak till de låga laddningarna var att de lokala politikernas närmast unisont tillbakavisande detta påstående.

Enligt tabell 6 var de flesta av 1990-talets lokala politiker anhängare av deltagaridealet. Ytterligare en indikation på de lokala politikernas tilltro till deltagaridealet kunde erhållas genom att ett index konstruerades på basis av de fyra påståenden som låg till grund för mätningen av den demokratiidealiska åsiktsdimensionen enligt faktoranalysen som presenterades i tabell 7 . Konstruktionen av indexet innebar att varje enskild politikers svar på de påståenden som ingick $i$ åsiktsdimensionen för demokratiideal poängsattes på en skala 1-5. Om politikerna hade svarat "instämmer helt" registrerades 1 poäng, "instämmer i stort sett" 2 poäng, "ingen åsikt, vet ej" 3 poäng, "delvis motsatt åsikt" 4 poäng och "helt motsatt åsikt" 5 poäng. Svarsalternativen på påståendet om att många förtroendevalda var bra för demokratin spegelvändes. Därefter summerades poängen för varje enskild lokal politiker och subtraherades med 4. På så sätt skapades en 17-gradig skala som varierade från 0 (starkast anhängare av det väljarinriktade idealet) och 16 (starkast anhängare av deltagaridealet). Värdet 8 markerade mitten på skalan. De lokala politiker vars värde på skalan understeg 8 var således närmare det väljarinriktade idealet än deltagaridealet. Om värdet överstiger 8 var de lokala politikerna mer orienterade mot deltagaridealet än det väljarinriktade idealet. Hur stor andel av de lokala politikerna som var placerade på skalans olika värden redovisas i figur 1 .

Enligt figur 1 var de flesta lokala politiker orienterade mot deltagaridealet. Medelvärdet för de lokala politikerna på den 17-gradiga demokratiidealskalan var 10,7. Medelvärdet för respektive parti är markerat med en fyrkant på kurvan i figur 1. Därmed visualiseras var på skalan den genomsnittlige lokala politikern för respektive parti var placerad 1999. De flesta partierna var tämligen nära varandra, men det fanns också skillnader. Socialdemokraterna var de som i störst utsträckning anslöt sig till deltagaridealet (medelvärde, $M=11,9$ ). Sedan kom de övriga partierna som pärlor på en rad: vänsterpartiet $(M=11,5)$, miljöpartiet 
$(M=11,1)$, folkpartiet $(M=11,0)$, centerpartiet $(M=10,7)$ och kristdemokraterna $(M=10,2)$. Det bör observeras att även om partierna låg tätt på linjen i figur 1 var den genomsnittliga skillnaden mellan kristdemokrater och socialdemokrater nästan 2 skalvärden, vilket är en åttondel av skalan.

Figur 1 De lokala politikernas fördelning utmed en demokratiidealskala 1999. Skalan varierar från 0 (starkast anhängare av och det väljarinriktade idealet) och 16 (starkast anhängare av deltagaridealet). Skalmedelvärdet för respektive parti är markerat med en fyrkant på kurvan.

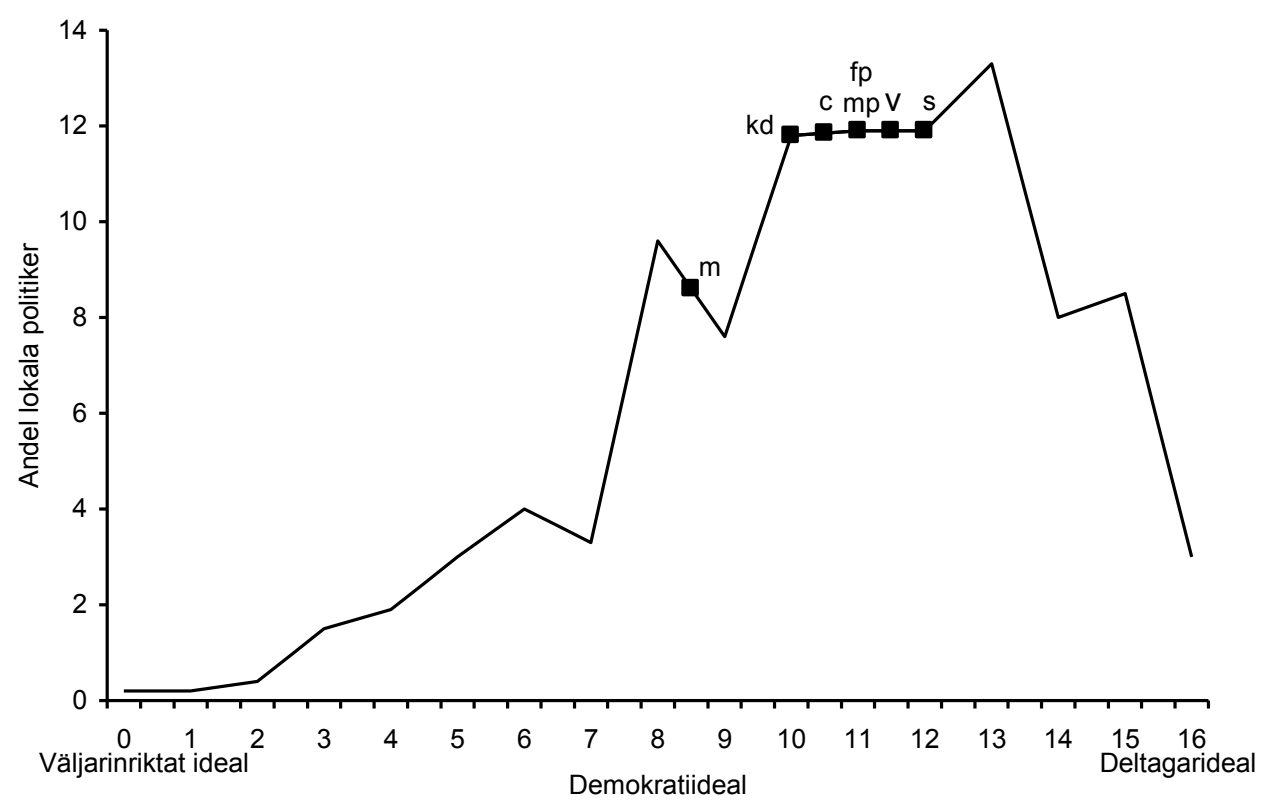

Jämfört med de övriga partierna var den genomsnittlige moderaten placerad närmare det väljarinriktade idealet $(\mathrm{M}=8,6)$. Avståndet mellan moderaterna och socialdemokraterna - de två partier som stod längst ifrån varandra på demokratiidealskalan - var drygt 3 skalvärden (ungefär en femtedel av skalan). Det betydde att de flesta moderater alltjämt tenderade att ha åsikter som liknade deltagaridealet mer än det väljarinriktade idealet. Men moderaterna var splittrade i frågan. Moderaternas spridning längs demokratiidealskalan var större än något annat parti. ${ }^{7}$ En intressant fråga var varför moderaterna var oeniga. Kan det vara så att moderaterna var i färd med att skifta demokratiideal, från deltagarideal till 
ett mer väljarinriktat ideal? Denna fråga diskuteras mer utförligt i denna artikels slutsatser. Men en indikation om vad som var på gång under 1990-talet var inte omöjlig att få. Låt oss anta att ett generationsskifte inom moderaterna var på gång. I så fall borde åsikterna bland yngre moderata politiker ha varit mer $\mathrm{i}$ överensstämmelse med det väljarinriktade idealet och mindre med deltagaridealet än vad som borde ha varit fallet med deras äldre partivänner. Förklaringen till ett sådant samband behöver i och för sig inte vara ett generationsskifte. ${ }^{8}$ Men för att ett generationsskifte ska ha varit en möjlig förklaring till åsiktsskillnaderna bland moderaterna måste de yngre moderaterna i större utsträckning än de äldre ha lutat åt det väljarinriktade idealet. Sambandet mellan ålder och placering på demokratiidealskalan visade sig vara att yngre moderater tenderade att ha varit något mer för det väljarinriktade idealet än sina äldre partivänner (Pearsons $\mathrm{r}=0,18$ ). Sambandet var svagt men statistiskt signifikant. I andra partier fanns inget motsvarande statistiskt signifikant samband. Den föreslagna förklaringen till moderaternas interna splittring fick därför stöd: det var mycket möjligt att moderaterna höll på att byta deltagaridealet mot det väljarinriktade idealet under 1990-talet.

Det var också möjligt att konstruera en motsvarande skala för dimensionen för styrförmåga som för dimensionen för demokratiidealet. Det fanns ett starkt samband mellan dimensionen för demokratiidealet och dimensionen för styrförmåga (Pearsons $\mathrm{r}=0,56$ ). Ju mindre styrförmåga en politiker upplevde, desto mer väljarinriktat ideal tenderade politikern att ha. Flera av frågorna om styrförmåga kunde ha uppfattats som en kritisk reaktion på deltagaridealet. Anhängare av det väljarinriktade idealet kunde kritisera förekomsten av många fritidspolitiker genom att påstå att de ändå inte hade något inflytande (maktkoncentration, tjänstemannainflytande). Dessutom ingick ett påstående $\mathrm{i}$ dimensionen för styrförmåga som när enkäten konstruerades avsåg att mäta de lokala politikernas inställning till det väljarinriktade idealet (nämndledamöterna uppfattas oftast som sektorsföreträdare). Detta kunde också ha länkat samman de båda dimensionerna ytterligare.

Det fanns ett svagt samband mellan åsikten om hur demokratin fungerade $\mathrm{i}$ den egna kommunen och demokratiideal: ju mer missnöje, desto större orientering mot det väljarinriktade idealet (Pearsons $r=0,14$ ). Sambandet mellan åsikten om hur demokratin fungerade i den egna kommen och skalan som anger styrförmåga 
var då stark: ju mindre styrförmåga, desto större missnöje med hur demokratin fungerade (Pearsons $r=0,35$ ).

Ovan - i samband med att tabell 3 diskuterades - nämndes att anhängare av det väljarinriktade idealet ofta tilldömdes åsikten att väljarna var okunniga. Dessutom antogs att deltagaridealets förespråkare mer än andra instämde i åsikten att för få väljare har haft erfarenhet av att vara förtroendevalda. Det fanns också ett statistiskt säkerställt samband mellan placering på demokratiidealskalan och åsikt om väljarnas kunnighet. Anhängarna av det väljarinriktade idealet tenderade att $\mathrm{i}$ större utsträckning än deltagaridealets förespråkare instämma i att väljarna hade dålig kunskap om kommunalpolitik, men sambandet var mycket svagt (Pearsons $\mathrm{r}=0,07)$. Dessutom instämde en majoritet av politikerna med både väljarinriktat ideal och deltagarideal med påståendet att väljarna var okunniga i kommunalpolitik. Också sambandet mellan demokratiidealskalan och påståendet att för få väljare hade erfarenhet av att vara kommunalt förtroendevalda hade ett svagt men signifikant samband som stödde tidigare antaganden. Lokala politiker som var anhängare av deltagaridealet tenderade att tycka att för få väljare hade erfarenhet av att vara kommunalt förtroendevalda (Pearsons $r=-0,09$ )

Sammanfattningsvis visade undersökningen att de flesta av 1990-talets lokala politiker i mycket stor omfattning slöt upp kring deltagaridealet. Undantaget var moderaterna där en stor grupp förespråkade ett mer väljarinriktat ideal.

\section{Maktfördelningen inom kommunen}

I den föreliggande studien var det inte vilka som helst som blev tillfrågade om den lokala representativa demokratin. Svarspersonerna var de lokala politiker som till stor del utformade de lokaldemokratiska institutionerna. Dessa organisationer kan ha utformats så att de gynnade deltagaridealet eller det väljarinriktade idealet. I detta avsnitt studeras för det första om 1990-talets lokala politiker ville ha en maktfördelning inom kommunen som stod i överensstämmelse med deltagaridealet eller det väljarinriktade idealet. För det andra diskuteras i vad mån 
de lokala politikerna faktiskt utformade sin kommunala organisation så att deltagaridealet eller det väljarinriktade idealet gynnades.

De lokala politikerna kunde försöka gynna deltagaridealet genom att de ville ge ökat inflytande till aktörer som associerades med decentraliserat inflytande och ett relativt omfattande deltagande. Tre aktörer som var relaterade till ett relativt omfattande deltagande och decentraliserat inflytande var lokala partiorganisationer, kommunala nämnder och enskilda förtroendevalda. Att vilja ge dessa tre aktörer ökat inflytande kunde gynna deltagaridealet, varför dessa aktörer i det följande markerats med ett kommunalhus (而). Men de lokala politikerna kunde även vilja gynna det väljarinriktade idealet genom att de förespråkade ett relativt stort inflytande för aktörer som innebar ett mer centraliserat inflytandet $i$ avsikt att öka möjligheterna till politisk styrning av kommunens verksamhet. I så fall ville man ge kommunstyrelsen och kommunalråden ett relativt stort inflytande, varför dessa aktörer i det följande markerats med en valurna ( $)$. Anhängare av båda demokratiidealen hade skäl att vilja öka inflytandet för kommunfullmäktige och dess partigrupper (markerade med både kommunalhus och valurna) samt minska de kommunala tjänstemännens inflytande (omarkerad). Anhängare av båda demokratiidealen borde haft för avsikt att på sinsemellan olika sätt öka väljarnas inflytande (markerad med både ett kommunalhus och en valurna). Lokalpolitikernas uppfattning i dessa frågor kommer att studeras genom att jämföra deras uppfattning om den faktiska maktfördelningen i kommunerna och sedan jämföra den med deras önskade maktfördelning. Först studeras lokalpolitikernas uppfattning om den maktfördelningen, sedan hur de önskar att makten skulle vara fördelad.

För att utreda de lokala politikernas åsikter om den faktiska maktfördelningen i kommunalpolitiken tillfrågades lokalpolitikerna hur mycket inflytande olika kommunalpolitiska aktörer hade. Frågan löd: "Kan du ange hur mycket inflytande följande aktörer har respektive bör ha när det gäller beslutsfattandet $\mathrm{i}$ allmänhet $\mathrm{i}$ Din kommun?" De lokala politikerna angav sitt svar med hjälp av en 11-gradig skala mellan 0 (mycket litet inflytande) och 10 (mycket stort inflytande). Utifrån de lokala politikernas svar beräknades medelvärdet, vilket multiplicerades med 10. Inflytandet bedömdes för följande aktörer: kommunfullmäktige, kommunstyrelsen, kommunalråden, kommunens nämnder, enskilda kommunalt förtroendevalda, partiernas fullmäktigegrupper, de lokala partiorganisationerna, 
kommunens tjänstemän och väljarna i kommunen. I tabell 8 redovisas de lokala politikernas uppfattning om vilket inflytande aktörerna hade.

Tabell 8 Lokala politikers uppfattning om nio politiska aktörers inflytande 1999 (medelvärde).

\begin{tabular}{|c|c|}
\hline Aktörer & Har inflytande \\
\hline Kommunstyrelsen & 86 \\
\hline Kommunalråden & 81 \\
\hline 而出Kommunfullmäktige & 71 \\
\hline 亚Kommunens nämnder & 70 \\
\hline Kommunens tjänstemän & 69 \\
\hline 而Partiernas fullmäktigegrupper & 65 \\
\hline 孟De lokala partiorganisationerna & 52 \\
\hline 孟Enskilda kommunalt förtroendevalda & 48 \\
\hline 亚Väljarna i kommunen & 46 \\
\hline
\end{tabular}

Kommentar: Frågan lydelse var "Kan du ange hur mycket inflytande följande aktörer har respektive bör ha när det gäller beslutsfattandet i allmänhet i Din kommun?" De lokala politikerna angav sitt svar med hjälp av en 11-gradig skala mellan 0 (mycket litet inflytande) och 10 (mycket stort inflytande). Utifrån de lokala politikernas svar beräknas medelvärdet, vilket multipliceras med 10.

Enligt de lokala politikernas beskrivning av den faktiska makten i kommunerna var den mer fördelad i enlighet med det väljarinriktade idealet än med deltagaridealet under 1990-talet. De lokala politikerna ansåg att kommunstyrelsen hade störst inflytande, följt av kommunalråden. Båda aktörerna ansågs ha betydligt större inflytande än kommunfullmäktige, kommunens nämnder och kommunens tjänstemän. Partiernas fullmäktigegrupper upplevdes som mer inflytelserika än de lokala partiorganisationerna. Minst inflytande av de här redovisade aktörerna ansåg de lokala politikerna att väljarna hade. De institutioner som ansågs gynna deltagaridealet (kommunens nämnder och de lokala partiorganisationerna) förknippade de flesta lokala politiker med relativt lågt inflytande.

I tabell 9 presenteras de lokala politikernas uppfattning av maktfördelningen efter parti. Störst skillnad rådde mellan socialdemokraterna och miljöpartisterna vad gällde inflytandet för kommunfullmäktige och partiernas fullmäktigegrupper. Jämfört med miljöpartisterna ansåg socialdemokraterna att dessa aktörer hade större inflytande. I övrigt var skillnaderna mellan partierna små. 
Tabell 9 Lokala politikers uppfattning om nio politiska aktörers inflytande 1999 efter parti (medelvärde).

\begin{tabular}{|c|c|c|c|c|c|c|c|}
\hline \multirow[b]{2}{*}{ Aktörer } & \multicolumn{7}{|c|}{ Parti } \\
\hline & $v$ & $s$ & $m p$ & $c$ & $f p$ & $k d$ & $m$ \\
\hline Kommunstyrelsen & 86 & 86 & 86 & 84 & 86 & 86 & 85 \\
\hline Kommunalråden & 83 & 82 & 84 & 78 & 80 & 79 & 81 \\
\hline 亚 Kommunfullmäktige & 66 & 76 & 63 & 64 & 67 & 73 & 69 \\
\hline 亚Kommunens nämnder & 68 & 72 & 67 & 71 & 66 & 72 & 70 \\
\hline Kommunens tjänstemän & 70 & 69 & 73 & 69 & 67 & 71 & 68 \\
\hline 亚Partiernas fullmäktigegrupper & 61 & 70 & 60 & 63 & 61 & 63 & 64 \\
\hline 亚De lokala partiorganisationerna & 50 & 56 & 50 & 49 & 49 & 52 & 49 \\
\hline$\overline{\mathrm{I}}$ Enskilda kommunalt förtroendevalda & 46 & 51 & 45 & 51 & 47 & 48 & 48 \\
\hline 衁VUäljarna i kommunen & 44 & 48 & 38 & 44 & 47 & 41 & 48 \\
\hline
\end{tabular}

Kommentar: Frågan lydelse är "Kan du ange hur mycket inflytande följande aktörer har respektive bör ha när det gäller beslutsfattandet i allmänhet i Din kommun?" De lokala politikerna angav sitt svar med hjälp av en 11-gradig skala mellan 0 (mycket litet inflytande) och 10 (mycket stort inflytande). Utifrån de lokala politikernas svar beräknas medelvärdet, vilket multipliceras med 10.

\section{Önskad maktfördelning}

Nästa steg är att analysera vilket inflytande 1990-talets lokala politiker ansåg att aktörerna bör ha. Detta önskade inflytande kan relateras till vilket inflytande som lokalpolitikerna upplevde att aktörerna hade, vilket redovisades i tabell 8 ovan. Ville de lokala politikerna att inflytandet ska öka eller minska? Innebär de lokala politikernas önskningar att de ville ha en maktfördelning som gick i riktning mot deltagaridealet eller det väljarinriktade idealet? I tabell 10 redovisas medelvärdet för vilket inflytande de lokala politikerna anser att aktörerna bör ha. Dessutom redovisas medelvärdesdifferensen som beräknats genom att subtrahera medelvärdet för vilket inflytande lokalpolitikerna upplevde att aktörerna hade från inflytandet de tyckte att de borde ha. På så vis erhålls ett numeriskt värde på omfattningen på den maktförändring som de lokala politikerna önskade och om de ansåg att aktörerna skulle haft mer eller mindre inflytelse. Ju högre positivt värde, desto mer inflytande jämfört med det upplevda inflytandet som lokalpolitikerna tyckte att aktören hade. Ju mer negativt värde, desto mindre inflytande än det upplevda inflytandet önskade lokalpolitikerna. 
Tabell 10 Lokala politikers uppfattning om vilket inflytande nio politiska aktörers borde ha haft 1999 (medelvärde och medelvärdesdifferens).

\begin{tabular}{|c|c|c|}
\hline Aktör & Bör ha inflytande & Differens bör ha - har \\
\hline 而Kommunfullmäktige & 89 & +18 \\
\hline 亚Kommunens nämnder & 80 & +10 \\
\hline Kommunstyrelsen & 78 & -8 \\
\hline 亚甜Väljarna $i$ kommunen & 75 & +29 \\
\hline III Partiernas fullmäktigegrupper & 71 & +6 \\
\hline Kommunalråden & 68 & -13 \\
\hline 孟De lokala partiorganisationerna & 62 & +10 \\
\hline 亚Enskilda kommunalt förtroendevalda & 60 & +12 \\
\hline Kommunens tjänstemän & 48 & -21 \\
\hline
\end{tabular}

Kommentar: Frågan lydelse var "Kan du ange hur mycket inflytande följande aktörer har respektive bör ha när det gäller beslutsfattandet i allmänhet i Din kommun?" De lokala politikerna angav sitt svar med hjälp av en 11-gradig skala mellan 0 (mycket litet inflytande) och 10 (mycket stort inflytande). Utifrån de lokala politikernas svar beräknas medelvärdet, vilket multipliceras med 10.

Om 1990-talets lokala politiker fått bestämma skulle maktfördelningen ha gynnat deltagaridealet mer än vad de upplevde att den gjorde 1999. Inflytandet skulle framförallt ha varit mindre centrerat till kommunstyrelsen och kommunalråden. Låt oss dock börja med att kommentera de lokala politikernas uppfattning om vilket inflytande de olika aktörerna borde ha haft. De lokala politikerna ville att kommunfullmäktige skulle ha klart mest inflytande. Kommunala nämnder ansåg de skulle ha näst mest inflytande och därefter kommunstyrelsen. Sedan följer väljarna i kommunen, partiernas fullmäktigegrupper, kommunalråden, de lokala partiorganisationerna, enskilda förtroendevalda och sist kommunens tjänstemän.

Vid en jämförelse mellan vilken maktförändring som lokalpolitikerna ville ha på 1990-talet, visade medelvärdesdifferensen i tabell 10 att de lokala politikerna ville öka väljarnas inflytande avsevärt. Även kommunfullmäktiges inflytande önskade de lokala politikerna att det var betydligt större än nu. Vad gällde de aktörer som var förknippade med deltagaridealet ville de lokala politikerna att deras inflytande skulle öka. Kommunala nämnder, de lokala partiorganisationerna och enskilda kommunalt förtroendevalda önskade de lokala politikerna att de skulle haft mer inflytande. Däremot tenderade de lokala politikerna att vilja minska inflytandet för de aktörer som i speciellt stor utsträckning associerades med det väljarinriktade idealet: kommunalråden och kommunstyrelsen. Men de aktörer 
som de lokala politikerna ville avlöva mest makt ifrån var kommunens tjänstemän. Nästan en tredjedel av det upplevda inflytandet önskade de ta ifrån kommunens tjänstemän.

I tabell 11 redovisas vilket inflytande de olika partiföreträdarna ansåg att aktörerna borde ha haft. Skillnaderna var större mellan partierna beträffande önskvärt inflytande jämfört med perception av faktisk maktfördelning. Störst var skillnaderna mellan socialdemokraterna och moderaterna angående vilket inflytande den lokala partiorganisationen borde ha haft. Överhuvudtaget önskade socialistiska lokalpolitiker att lyfta fram inflytandet för partikollektivet i större utsträckning än övriga partier. Vänsterpartisterna och miljöpartisterna ville ge kommunstyrelsen relativt lite inflytande.

Tabell 11 Lokala politikers uppfattning om vilket inflytande nio politiska aktörers borde ha haft 1999, efter parti (medelvärde).

\begin{tabular}{|c|c|c|c|c|c|c|c|}
\hline \multirow[b]{2}{*}{ Aktör } & \multicolumn{7}{|c|}{ Parti } \\
\hline & $v$ & $s$ & $m p$ & $c$ & $f p$ & $k d$ & $m$ \\
\hline 孟Kommunfullmäktige & 90 & 91 & 89 & 86 & 89 & 90 & 88 \\
\hline 亚Kommunens nämnder & 79 & 82 & 77 & 79 & 78 & 79 & 79 \\
\hline Eommunstyrelsen & 74 & 80 & 70 & 77 & 80 & 81 & 79 \\
\hline 血Väljarna i kommunen & 80 & 76 & 74 & 73 & 76 & 70 & 74 \\
\hline 孟 Partiernas fullmäktigegrupper & 71 & 78 & 67 & 68 & 68 & 67 & 68 \\
\hline Kommunalråden & 62 & 68 & 63 & 69 & 70 & 71 & 70 \\
\hline 亚De lokala partiorganisationerna & 63 & 71 & 59 & 59 & 58 & 56 & 54 \\
\hline 亚 Enskilda kommunalt förtroendevalda & 59 & 62 & 56 & 63 & 59 & 58 & 59 \\
\hline Kommunens tjänstemän & 48 & 47 & 51 & 50 & 48 & 52 & 47 \\
\hline
\end{tabular}

Kommentar: Frågan lydelse var "Kan du ange hur mycket inflytande följande aktörer har respektive bör ha när det gäller beslutsfattandet i allmänhet i Din kommun?" De lokala politikerna angav sitt svar med hjälp av en 11-gradig skala mellan 0 (mycket litet inflytande) och 10 (mycket stort inflytande). Utifrån de lokala politikernas svar beräknas medelvärdet, vilket multipliceras med 10.

\section{Demokratiideal och maktfördelning}

Vi har redan konstaterat att de flesta av 1990-talets lokala politiker önskade förändra maktfördelningen i kommunen på så sätt att deltagaridealet gynnades. Vi har också konstaterat att de flesta lokala politiker var orienterade mot deltagaridealet, inte det väljarinriktade idealet. Rimligtvis borde de lokala 
politiker som förordade deltagaridealet vilja förändra maktförhållanden så att deltagaridealet gynnades, medan de som förordade det väljarinriktade idealet inte borde ha varit lika angelägna att göra det samma. De lokala politiker som förespråkade deltagaridealet borde ha indikerat sin vilja till maktförändring genom att ge högre poäng till kommunala nämnder, lokala partiorganisationer och enskilda förtroendevalda i jämförelse med de vars ideal var mer väljarinriktat. I tabell 12 är det möjligt att se om så är fallet. Där presenteras åsikterna om vilket inflytande aktörerna borde ha haft uppdelat på lokala politiker som enligt demokratiidealskalan var orienterade mot deltagaridealet respektive det väljarinriktade idealet. Som mått användes medelvärde och medelvärdesdifferens. För att beräkna medelvärdesdifferensen subtraherades de lokala politiker som var orienterade mot det väljarinriktade idealet från de om var orienterade mot deltagaridealet. En positiv medelvärdesdifferens indikerade att anhängarna av deltagaridealet i större utsträckning än det väljarinriktade idealets anhängare önskade att dessa aktörer skulle ha ett större inflytande än vad de som var orienterade mot det väljarinriktade idealet önskade. Så borde det vara vad gäller de aktörer som var förknippade med deltagaridealet, medan de aktörer som kopplades till det väljarinriktade idealet borde uppvisa en negativ medelvärdesdifferens. Vilket demokratiideal som är relaterad till vilken aktör framgår av resonemanget i samband med tabell 8 samt indikeras genom ett kommunhus (䍏) för deltagaridealet och en valurna (4) för det väljarinriktade idealet.

De lokala politiker som var orienterade mot deltagaridealet ville ge de lokala partigrupperna, kommunens nämnder och enskilda ledamöter mer inflytande än de som var orienterade mot det väljarinriktade idealet. Samma sak gällde partiernas fullmäktigegrupper och kommunfullmäktige samt väljarna i kommunen. Undantaget de lokala partiorganisationerna och fullmäktigegrupperna var dock skillnaderna små, men procentdifferenserna gick i hypotesens riktning. Lokala politiker orienterade mot deltagaridealet ville således i särskild stor utsträckning ge inflytande till kommunalpolitiska aktörer som var associerade till deltagaridealets förverkligande.

Tilläggas kan att analyserna visade att gräset alltjämt var grönare på andra sidan: kommunfullmäktige uppfattades som mer inflytelserikt av de som inte satt i fullmäktige än av fullmäktigeledamöterna själva. 
Tabell 12 Lokala politikers uppfattning om vilket inflytande nio politiska aktörers borde ha haft, efter demokratiideal (medelvärde och medelvärdesdifferens).

\begin{tabular}{|c|c|c|c|}
\hline \multirow[b]{2}{*}{ Aktör } & \multicolumn{2}{|c|}{ Demokratiideal } & \multirow{2}{*}{$\begin{array}{c}\text { Differens } \\
\text { deltagarideal- } \\
\text { väljarinriktat } \\
\text { ideal } \\
\end{array}$} \\
\hline & Deltagarideal & Väljarinriktat ideal & \\
\hline 亚De lokala partiorganisationerna & 63 & 43 & +20 \\
\hline 孟 Partiernas fullmäktigegrupper & 71 & 61 & +10 \\
\hline 而 Kommunfullmäktige & 90 & 81 & +9 \\
\hline 孟Kommunens nämnder & 80 & 74 & +6 \\
\hline 孟Enskilda kommunalt förtroendevalda & 60 & 54 & +6 \\
\hline 衁和Väljarna i kommunen & 75 & 70 & +5 \\
\hline Kommunstyrelsen & 78 & 78 & 0 \\
\hline Kommunens tjänstemän & 47 & 52 & -5 \\
\hline Kommunalråden & 68 & 73 & -5 \\
\hline
\end{tabular}

Kommentar: Frågan lydelse var "Kan du ange hur mycket inflytande följande aktörer har respektive bör ha när det gäller beslutsfattandet i allmänhet i Din kommun?" De lokala politikerna angav sitt svar med hjälp av en 11-gradig skala mellan 0 (mycket litet inflytande) och 10 (mycket stort inflytande). Utifrån de lokala politikernas svar beräknas medelvärdet, vilket multipliceras med 10. Operationaliseringen av deltagarideal och det väljarinriktade idealet bygger på det index som konstruerades och presenterades i förgående kapitel. Indexet varierar mellan 0 (stark anhängare av det väljarinriktade idealet) och 16 (stark anhängare av deltagaridealet). Svarspersoner med indexvärdena 0-7 betraktas som anhängare av det väljarinriktade idealet, Svarspersoner med indexvärdena 9-16 betraktas som anhängare av deltagaridealet. Svarspersoner med indexvärde 8 betraktas som neutrala (redovisas ej i tabell 12).

Analyserna om maktfördelningen i kommunerna kan nu sammanfattas. De lokala politikerna uppfattning om den faktiska maktfördelningen i kommunerna liknade till stor del det väljarinriktade idealet. De flesta lokala politiker önskade dock att maktfördelningen vore annorlunda. Den önskade förändringen var i överensstämmelse med deltagaridealet.

\section{Politikermisstro}

I en representativ demokrati är folkets förtroende av största betydelse. Folket representanter bör uppfattas som legitima. Vid ett långvarigt lågt förtroende för 
politikerna hos väljarna finns risken att de representativa institutionerna förlorar $\mathrm{i}$ legitimitet. Deltagande i den lokala representativa demokratin avser att motverka förlorad legitimitet och en tilltagande politikermisstro. En effekt som anhängarna av deltagaridealet önskar är att det ska finnas många kanaler mellan väljare och valda. Förhoppningen är att det ska finnas många kanaler mellan väljare och valda som upprätthåller den representativa demokratins legitimitet och ett högt förtroende för politikerna. Ett högt deltagande hoppas de leder till många sådana kanaler (Brothén \& Gilljam 2006).

Figur 2 "Partierna är bara intresserade av folks röster men inte av deras åsikter." Andel som instämmer helt eller instämmer delvis

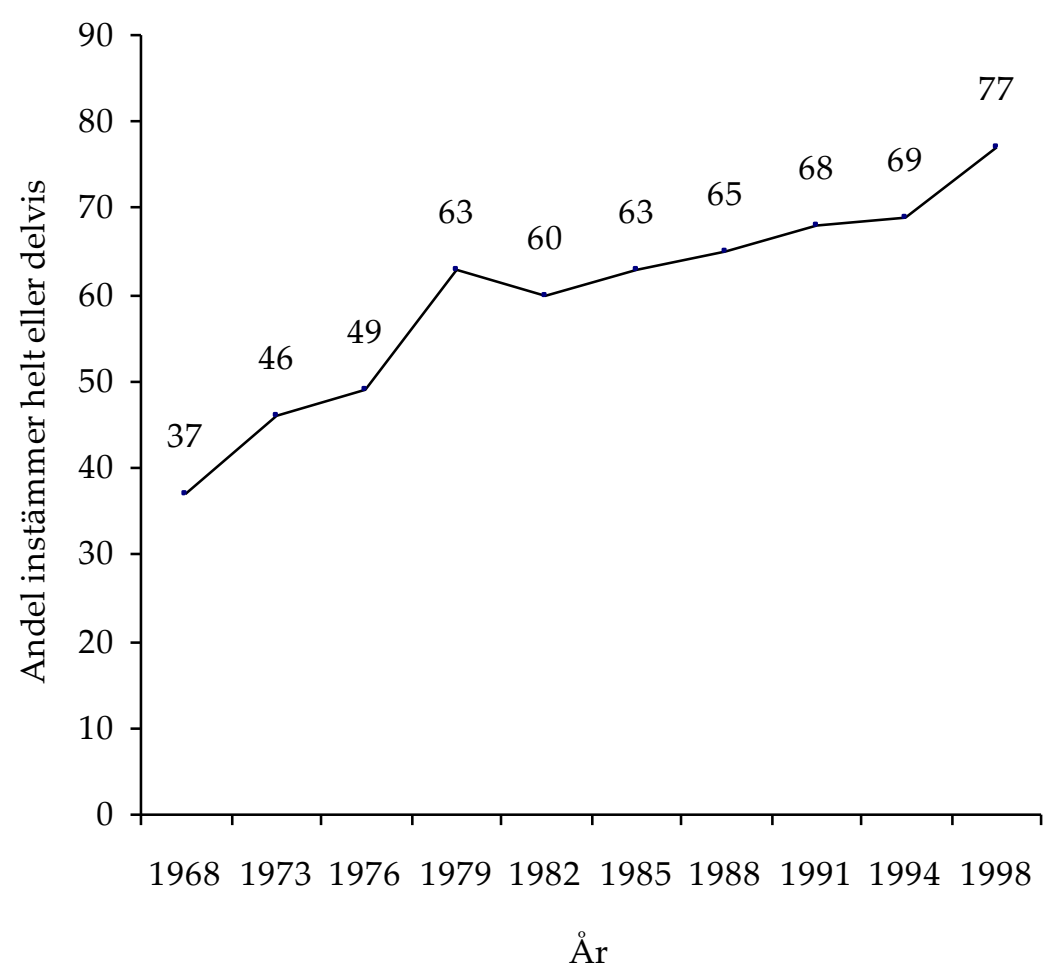

Kommentar: Data är hämtade från väljarundersökningarna, Statsvetenskapliga institutionen, Göteborgs universitet. 
Enligt deltagaridealet kan vanliga medborgare dessutom få ökat förtroende för politiker i den lokala representative demokratin genom att själva delta som politiker.

På 1990-talet visade de flesta undersökningar på ett avtagande förtroende för politiker. Den längsta tidsserien som undersökt politikerförtroende var då från Valforskningsprogrammet på Göteborgs universitet. Ett representativt urval av de svenska väljarna ställdes då inför följande påstående: "Partierna är bara intresserade av folks röster men inte av deras åsikter." (Holmberg 2000: 32-34). Mätningarna genomfördes i samband med de allmänna valen mellan 1968 och 1998. I figur 2 redovisas hur många som instämde helt eller delvis i påståendet.

Under en tidsperiod på 30 år hade andelen som instämde helt eller delvis med påståendet att partierna bara var intresserade av folks röster men inte deras åsikter mer än fördubblats. Under 1990-talet ökade andelen instämmanden med 12 procentenheter. På 1990-talet brede politikermisstron ut sig. Det vi nu vet, men som lokalpolitikerna inte visste 1999, är att politikermisstroendet har minskat sedan 1998. Istället har väljarnas förtroende för politikerna ökat. Om mätserien som redovisas i figur 2 dras ut till 2010 så är politikermisttroende nere på den nivå som den hade på 1970-talet. Frågan var dock hur de lokala politikerna uppfattade situationen 1999? Upplevde de att förtroendet bland politikerna hade minskat bland väljarna? I vår undersökning ställdes de lokala politikerna inför följande påstående: "Förtroendet för politiker har minskat bland väljarna under 1990-talet." I tabell 13 redovisas andelen som instämde helt, instämde i stort sett, hade delvis motsatt åsikt och helt motsatt åsikt.

En överväldigande majoritet av de lokala politikerna instämde i att förtroendet för politiker hade minskat under 1990-talet. Med tanke på att undersökningar om medborgarnas politikerförtroende uppgav samma sak skulle ett motsatt resultat ha varit förvånande. 
Tabell 13 Anser de lokala politikerna att förtroendet för politiker har minskat bland väljarna under 1990-talet (procent och opinionsbalans)?

\begin{tabular}{lr}
\hline Instämmer helt & 41 \\
Instämmer $i$ stort sett & 48 \\
Delvis motsatt åsikt & 10 \\
Helt motsatt åsikt & 1 \\
\hline Summa procent & 100 \\
Antal svarande & 1745 \\
\hline Opinionsbalans & +78 \\
\hline
\end{tabular}

Kommentar: Opinionsbalansen beräknas genom att subtrahera procentandelen som har delvis eller helt motsatt åsikt från procentandelen som instämmer helt eller i stort sett. Frågan löd: "Om Du ser till demokratin i Din egen kommun, hur ställer Du Dig till följande påståenden?" Varefter bland annat "Förtroendet för politiker har minskat under 1990-talet" nämndes.

\section{Vad som riskerar att öka politikermisstron}

Vad som kunde vara av större intresse var vad de lokala politikerna såg som orsaken till det minskade förtroendet för politiker. Deltagaridealets anhängare skulle kunna påstå att en orsak till det minskade förtroendet var att deltagandet $\mathrm{i}$ den representativa demokratin var för lågt, att det fanns för få fritidspolitiker och för många professionella politiker.

Vi frågade därför vad de lokala politikerna trodde riskerade minska väljarnas förtroende för politiker. Naturligtvis frågades lokalpolitikerna om de trodde att för få fritidspolitiker och för många professionella politiker riskerade att minska väljarnas politikerförtroende. Med tanke på att våra tidigare resultat (se ovan) visade att de flesta lokala politiker var orienterade mot deltagaridealet på 1990talet, borde många av dem ha sett risker med få fritidspolitiker och många politikerproffs.

Vi gav de lokala politikerna nio förslag på vad som riskerade att öka politikermisstron. Självkritiska lokala politiker kunde uppge att överdrivna löften från politikers sida, för många "affärer" och skandaler med politiker inblandade samt mindre skickliga politiker idag än förr riskerade att minska förtroendet. Men det var även möjligt att nämna andra aktörer än lokala politiker. Vad som ofta fick uppmärksamhet i massmedia var, då som nu, rikspolitiken. Kanske smittade 
väljarnas bristande förtroende för rikspolitiker av sig på lokala politiker? Det var också möjligt att kritisera det sätt som massmedia och journalister bevakade politiken. Konflikter och skandaler uppmärksammades, medan den grå vardagen då allt gick som det skulle inte ägnades många spaltmeter (Bromander 2012, 2014).

Tabell 14 Vad riskerar att öka politikermisstron? De lokala politikernas syn på nio möjliga risker 1999 (procent och opinionsbalans).

\begin{tabular}{|c|c|c|c|c|c|c|c|c|}
\hline & $\begin{array}{l}\text { Mycket } \\
\text { stor risk }\end{array}$ & $\begin{array}{l}\text { Ganska } \\
\text { stor risk }\end{array}$ & $\begin{array}{l}\text { Varken } \\
\text { stor eller } \\
\text { liten risk }\end{array}$ & $\begin{array}{l}\text { Ganska } \\
\text { liten risk }\end{array}$ & $\begin{array}{l}\text { Mycket } \\
\text { liten risk }\end{array}$ & $\begin{array}{l}\text { Summa } \\
\text { procent }\end{array}$ & $\begin{array}{l}\text { Antal } \\
\text { svarande }\end{array}$ & $\begin{array}{c}\text { Opinions- } \\
\text { balans }\end{array}$ \\
\hline $\begin{array}{l}\text { Olika "affärer" och skandaler } \\
\text { med politiker inblandade }\end{array}$ & 76 & 20 & 3 & 1 & 0 & 100 & 1679 & +92 \\
\hline $\begin{array}{l}\text { Överdrivna löften från politikers } \\
\text { sida }\end{array}$ & 46 & 46 & 6 & 2 & 0 & 100 & 1682 & +90 \\
\hline $\begin{array}{l}\text { Journalister sätt att bevaka } \\
\text { politiken }\end{array}$ & 41 & 40 & 11 & 6 & 2 & 100 & 1663 & +73 \\
\hline $\begin{array}{l}\text { Minskat förtroende för } \\
\text { rikspolitiker hotar att leda } \\
\text { till minskat förtroende } \\
\text { för kommunalpolitiker }\end{array}$ & 30 & 49 & 15 & 5 & 1 & 100 & 1667 & +73 \\
\hline $\begin{array}{l}\text { Kärvare ekonomiska } \\
\text { tider }\end{array}$ & 21 & 43 & 25 & 9 & 2 & 100 & 1671 & +53 \\
\hline $\begin{array}{l}\text { 衁För många "professionella" } \\
\text { politiker }\end{array}$ & 17 & 41 & 28 & 12 & 2 & 100 & 1665 & +44 \\
\hline $\begin{array}{l}\text { 孟För få } \\
\text { fritidspolitiker }\end{array}$ & 19 & 35 & 28 & 14 & 4 & 100 & 1648 & +36 \\
\hline $\begin{array}{l}\text { Minskad auktoritetstro } \\
\text { bland väljarna }\end{array}$ & 16 & 32 & 3 & 11 & 4 & 100 & 1653 & +33 \\
\hline $\begin{array}{l}\text { Mindre skickliga politiker } \\
\text { idag än förr }\end{array}$ & 10 & 25 & 38 & 20 & 7 & 100 & 1647 & +8 \\
\hline
\end{tabular}

Kommentar: Opinionsbalansen beräknas genom att subtrahera procentandelen mycket liten risk och ganska liten risk från procentandelen mycket stor risk och ganska stor risk. Frågan löd: "Hur stor tror Du risken är att följande saker minskar väljarnas förtroende för politiker?"

Det minskade förtroendet för politiker kunde även ha berott på strukturella faktorer. Två strukturella faktorer kan ha varit ekonomi och värdeförändringar hos befolkningen. Flera kommuner hade under 1990-talet fått dra in på svångremmen. Besparingar var sällan populära, vilket kunde ha uppfattats vara en grogrund till ett ökat politikermisstroende bland väljarna. Andra menade att det ökade 
politikermisstroendet var en del av samhällsutvecklingen. Människor agerade mer självständigt mot vad som förr uppfattades som auktoriteter (Bjereld \& Demker 2005). En minskad auktoritetstro kunde således ha varit en orsak till minskande förtroende för politiker bland väljarna. I tabell 14 redovisas hur stor andel av de lokala politikerna som uppfattade att olika förhållanden var en mycket stor risk, ganska stor risk, varken liten eller stor risk, ganska liten risk och mycket liten risk för att väljarnas förtroende för politiker minskade. I tabell 14 redovisas även opinionsbalansen (ob). I detta fall beräknades opinionsbalansen som följer. Andelen som svarade mycket liten risk eller ganska liten risk subtraherades från andelen som svarade mycket stor risk eller ganska liten risk. Risker som visade på värderingar enligt deltagaridealet var markerade med ett kommunalhus (佥).

De flesta lokala politiker ansåg att nästan samtliga av de nämnda faktorerna riskerade att öka politikermisstron. Framförallt tenderade de lokala politikerna att vara självkritiska. Nästa alla menade att politiska affärer och skandaler $(\mathrm{ob}=+92)$ samt överdrivna löften $(\mathrm{ob}=+85)$ riskerade att minska politikerförtroendet. Däremot var det bara en minoritet som menade att det var mindre skickliga politiker idag än förr som riskerade att minska förtroendet $(o b=+8)$. Men 1990talets lokalpolitiker tyckte inte att de bara hade sig själva att skylla. De ansåg också att förhållandena på nationell nivå riskerade att smitta av sig till den lokala nivån. En stor majoritet av de lokala politikerna menade att minskat förtroende för rikspolitiker riskerar att leda till minskat förtroende för kommunalpolitiker $(\mathrm{ob}=+73)$. Dessutom uppgav de flesta lokalpolitiker att journalisters sätt att bevaka politiken riskerade att leda till politikermisstro (ob=+73). En stor del av de lokala politikerna ansåg att strukturella faktorer utanför deras egen kontroll riskerade att öka politikermisstron: framförallt en kärvare ekonomi $(\mathrm{ob}=+53)$ men också till viss del en minskande auktoritetstro $(o b=+33)$ riskerade att öka politikermisstron.

Två av de föreslagna förklaringarna till ökad politikermisstro var kopplade till deltagaridealet. En majoritet av de lokala politikerna ansåg att få fritidspolitiker $(\mathrm{ob}=+36)$ och för många politikerproffs $(\mathrm{ob}=+44)$ riskerade att öka politikermisstron. Med tanke på de lokala politikernas stöd för deltagaridealet var detta resultat förväntat. Men samtidigt bör man notera att mer än var fjärde lokalpolitiker ansåg att andelen fritidspolitiker eller politikerproffs varken utgjorde en stor eller liten risk för väljarnas politikerförtroende. 


\section{Partierna och politikermisstron}

Fanns det några skillnader mellan partierna beträffande synen på vad som riskerade att öka politikermisstron? I tabell 15 redovisas opinionsbalansen för partierna för respektive förklaring till politikermisstroende.

Tabell 15 Vad som riskerar att öka politikermisstron efter parti 1999: de lokala politikernas syn på nio möjliga risker efter parti (opinionsbalans).

\begin{tabular}{|c|c|c|c|c|c|c|c|c|}
\hline & \multicolumn{8}{|c|}{ Parti } \\
\hline & $v$ & $s$ & $m p$ & $c$ & $k d$ & $f p$ & $m$ & övriga \\
\hline $\begin{array}{l}\text { Olika "affärer" och skandaler } \\
\text { med politiker inblandade }\end{array}$ & +97 & +93 & +100 & +93 & +96 & +91 & +95 & +91 \\
\hline $\begin{array}{l}\text { Överdrivna löften från politikers } \\
\text { sida }\end{array}$ & +93 & +87 & +87 & +92 & +94 & +89 & +94 & +93 \\
\hline $\begin{array}{l}\text { Journalister sätt att bevaka } \\
\text { politiken }\end{array}$ & +79 & +76 & +64 & +69 & +73 & +66 & +71 & +53 \\
\hline $\begin{array}{l}\text { Minskat förtroende för } \\
\text { rikspolitiker hotar att leda } \\
\text { till minskat förtroende } \\
\text { för kommunalpolitiker }\end{array}$ & +75 & +75 & +76 & +72 & +76 & +63 & +69 & +83 \\
\hline $\begin{array}{l}\text { Kärvare ekonomiska } \\
\text { tider }\end{array}$ & +32 & +61 & +43 & +60 & +54 & +46 & +46 & +47 \\
\hline $\begin{array}{l}\text { 而För många "professionella" } \\
\text { politiker }\end{array}$ & +66 & +43 & +60 & +45 & +35 & +38 & +41 & +94 \\
\hline $\begin{array}{l}\text { 孟För få } \\
\text { fritidspolitiker }\end{array}$ & +54 & +47 & +46 & +45 & +37 & +47 & +7 & +13 \\
\hline $\begin{array}{l}\text { Minskad auktoritetstro } \\
\text { bland väljarna }\end{array}$ & +11 & +34 & +21 & +33 & +39 & +32 & +40 & +33 \\
\hline $\begin{array}{l}\text { Mindre skickliga politiker } \\
\text { idag än förr }\end{array}$ & +8 & +6 & -5 & +17 & +10 & -3 & +8 & +26 \\
\hline
\end{tabular}

Kommentar: Opinionsbalansen beräknas genom att subtrahera procentandelen mycket liten risk och ganska liten risk från procentandelen mycket stor risk och ganska stor risk. Frågan löd: "Hur stor tror Du risken är att följande saker minskar väljarnas förtroende för politiker?"

De två mest partiskiljande åsikterna om vad som riskerade att leda till ökat politikermisstroende rörde båda deltagaridealet: för många politikerproffs och för få fritidspolitiker. Medan en stor majoritet av vänsterpartisterna ansåg att för få fritidspolitiker riskerade att öka politikermisstroendet $(\mathrm{ob}=+54)$ delades åsikten av betydligt färre moderater $(\mathrm{ob}=+7)$. Också åsikten att för många professionella 
politiker riskerade att öka politikermisstron förfäktades främst av vänsterpartisterna $(\mathrm{ob}=+66)$. Däremot var inte kristdemokraterna lika trosvissa om risken med professionella politiker $(\mathrm{ob}=+35)$.

Vänsterpartisterna var inte lika övertygade att minskad auktoritetstro $(\mathrm{ob}=+11)$ och kärvare ekonomi $(\mathrm{ob}=+32)$ riskerade att leda till ökad politikermisstro. Partier som på 1990-talet i större utsträckning hade medverkat i beslut om olika besparingsprogram (Möller 2015) menade dock att kärvare ekonomiska tider riskerade att öka politikermisstron: socialdemokraterna $(\mathrm{ob}=+61)$ och centerpartiet $(\mathrm{ob}=+60)$. Bland centerpartisterna var det något fler än i övriga partier som ansåg att brist på skicklighet hos dagens politiker riskerade att öka politikermisstron $(o b=+17)$. Förhållandet var det motsatta bland miljöpartisterna (ob=-5) och folkpartisterna $(o b=-3)$. Vad gällde bedömning av riskerna för ökat politikermisstroende på grund av journalisters sätt att bevaka politiken, överdrivna löften från politikers sida, skandaler och affärer med politiker inblandade samt att minskat förtroende för rikspolitiker smittade av sig till lokalpolitikerna fanns inga nämnvärda skillnader mellan partierna.

Låt oss sammanfatta. De flesta undersökningar av väljarnas förtroende för politiker visade att förtroendet minskade under 1990-talet. Så uppfattade även de lokala politikerna läget 1999. Främst ansåg de att politikernas eget agerande riskerade att öka politikermisstroendet, låt vara att rikspolitikerna ansågs orsaka en del av misstroendet även på lokal nivå. De lokala politikerna utpekade även journalisternas sätt att bevaka politiken som en risk för minskat politikerförtroende. I en inte ringa utsträckning ansåg de flesta lokala politiker att för få fritidspolitiker och för många professionella politiker också minskade politikerförtroendet. Det stora undantaget utgjordes av moderaterna som ansåg att få fritidspolitiker inte nödvändigtvis riskerade att orsaka ett minskat förtroende för politiker. 


\section{Typ av deltagande}

Lika möjligheter till deltagande och inflytande är en av demokratins grundläggande normer. Det är dock svårt att i verkligheten upprätthålla dessa normer. I samhället finns olika grupper. Dessa kan vara över- eller underrepresenterade bland deltagarna i den lokala representativa demokratin. En samhällsgrupp är underrepresenterad om de har en lägre andel deltagare än vad deras andel av den röstberättigade befolkningen är. En samhällsgrupp är överrepresenterad om de har en större andel deltagare än vad deras andel av den röstberättigade befolkningen är. Om olika samhällsgrupper är under- och överrepresenterade indikerar det att medborgare som tillhör olika samhällgrupper inte har lika möjligheter till deltagande och inflytande i den lokala representative demokratin. Detta står emot det demokratiska idealet om lika deltagande och inflytande. Den centrala frågan att besvara i detta och de närmast följande kapitlen är således vilka samhällsgrupper som är över- och underrepresenterade i sitt deltagande $\mathrm{i}$ den lokala representativa demokratin. Men vad menas med deltagande?

Politiskt deltagande kan bland annat analyseras utifrån tre aspekter: typ, sakområden och kvalitet. I detta kapitel studeras typ av deltagande. Med typ av deltagande avses de olika aktiviteter och funktioner som kan användas när medborgaren försöker påverka politiken. Denna undersökning är koncentrerad till att analysera deltagande $i$ den lokala representativa demokratin. Den deltagandetyp som undersöks är då kommunala förtroendeuppdrag. Men även inom den lokala representativa demokratin finns olika typer av deltagande. En del av deltagandetyperna som undersöks är av formell art. Lokala politiker kan vara ordförande, andra är ledamöter eller suppleanter. Somliga har flera uppdrag medan andra upprätthåller ett uppdrag. En annan typ av deltagande omfattar en mindre formaliserad sida av förtroendeuppdraget. Förtroendevalda ska hålla kontakt med övriga medborgare och fungera som kanaler ut i samhället - detta är något som anhängare av deltagaridealet gärna framhäver. Sådana kontakter kan ske på många sätt. I det följande kommer två indikatorer att analyseras: de lokala politikernas kontaktnät med olika samhällsaktörer och de lokala politikernas egen föreningsaktivitet. 


\section{Vem är lokal politiker?}

Den primära typen av deltagande i denna undersökning var lokala politiker, det vill säga kommunalt förtroendevalda. Den första analysen rör vilka det var som deltog som kommunalt förtroendevald 1999. På sätt besvaras följande fråga: Vilka samhällsgrupper var över- respektive underrepresenterade i den lokala representativa demokratin 1999? I tabell 16 redovisas olika samhällsgruppers deltagande i den lokala representativa demokratin 1999 och i vilken mån de var över- respektive underrepresenterade. Som mått på över- och underrepresentation används procentdifferens (pd). I detta fall beräknas procentdifferensen genom att subtrahera procentandel röstberättigad befolkning från procentandel lokala politiker.

Några samhällsgrupper var starkt under- respektive överrepresenterade. Främst gällde skevheterna $\mathrm{i}$ deltagande faktorer som var relaterade till utbildning och yrke. Lågutbildade var underrepresenterade $(\mathrm{pd}=-21)$ och högutbildade var överrepresenterade $(\mathrm{pd}=+20)$. Personer anställda $\mathrm{i}$ privat sektor var underrepresenterade $(\mathrm{pd}=-21)$ medan kommunal- och landstingsanställda var överrepresenterade $(\mathrm{pd}=+17)$. Arbetare var underrepresenterade $(\mathrm{pd}=-25)$ samtidigt som tjänstemän var överrepresenterade (sammanlagd $\mathrm{pd}=+29)$.

Även ålder hade betydelse. Inom svensk 1990-talspolitik var startsträckan lång. Det fanns dessutom en ättestupa i svensk politik. Yngre under 30 år $(\mathrm{pd}=-13)$ och de som var 67 år och äldre $(\mathrm{pd}=-12)$ var underrepresenterade medan de medelålders (45-66 år) var kraftigt överrepresenterade (sammanlagd pd=+31).

Föreställningar om att religiositet - speciellt frikyrklighet - påverkade politiskt deltagande har varit vanliga (se t.ex. Elofsson 1996). De som besökte religiösa möten var också överrepresenterade och de som inte besökte religiösa möten var underrepresenterade ( $\mathrm{pd}=-18)$. Eftersom unga var underrepresenterade som lokala politiker samtidigt som äldre oftare var mer religiöst aktiva skulle det vara möjligt att ålder förklarade sambandet mellan religiösa mötesbesök och andelen lokala politiker. Men förhållandet mellan religiösa mötesbesök och andelen lokala politiker kvarstod i huvudsak även efter det att ålder hade beaktats. 
Mer än var tionde person i den svenska 1990-talsbefolkningen var född utomlands. Räknades även andra generationen med utländsk bakgrund - de som hade minst en förälder som fötts utomlands - var nästan var femte person i Sverige av utländsk härkomst. De flesta invandrare som stannade permanent $i$ Sverige blev svenska medborgare. Endast var tjugonde invånare i Sverige var utländsk medborgare. Hur välrepresenterade var dessa grupper i den lokala representativa demokratin?

Tabell 16 Olika samhällsgruppers deltagande i den lokala representativa demokratin. Vilka grupper var över- respektive underrepresenterade? En jämförelse mellan lokala politiker 1999 och den röstberättigade befolkningen 1998 (procent och procentdifferens).

\begin{tabular}{|c|c|c|c|}
\hline & $\begin{array}{c}\text { Lokala } \\
\text { politiker }\end{array}$ & $\begin{array}{c}\text { Röstberättigad } \\
\text { befolkning }\end{array}$ & Procentdifferens \\
\hline \multicolumn{4}{|l|}{ Kön' ${ }^{1}$} \\
\hline Män & 57 & 49 & +8 \\
\hline Kvinnor & 43 & 51 & -8 \\
\hline \multicolumn{4}{|l|}{ Ålder ${ }^{1}$} \\
\hline 18-29 år & 6 & 19 & -13 \\
\hline $30-44 a ̊ r$ & 21 & 27 & -6 \\
\hline $45-54$ & 32 & 18 & +14 \\
\hline $55-66$ år & 33 & 16 & +17 \\
\hline 67-år & 8 & 20 & -12 \\
\hline \multicolumn{4}{|l|}{ Civilstånd $^{2}$} \\
\hline Ensamstående & 11 & 10 & +1 \\
\hline Gift/sambo & 78 & 71 & +7 \\
\hline Frånskild & 8 & 11 & -3 \\
\hline Änka/änkeman & 3 & 8 & -5 \\
\hline \multicolumn{4}{|l|}{ Utbildningsnivå $^{3}$} \\
\hline Låg & 29 & 50 & -21 \\
\hline Medel & 23 & 22 & +1 \\
\hline Hög & 48 & 28 & +20 \\
\hline \multicolumn{4}{|l|}{ Typ av anställning ${ }^{3}$} \\
\hline Heltidsanställd & 55 & 48 & +7 \\
\hline Deltidsanställd & 8 & 11 & -3 \\
\hline Pensionär & 15 & 23 & -8 \\
\hline Studerande & 4 & 9 & -5 \\
\hline Arbetslös & 4 & 5 & -1 \\
\hline Annat & 14 & 4 & +10 \\
\hline
\end{tabular}


Tabell 16 forts.

\begin{tabular}{|c|c|c|c|}
\hline \multicolumn{4}{|l|}{ Anställningssektor ${ }^{3}$} \\
\hline Privat & 37 & 58 & -21 \\
\hline Statlig & 16 & 12 & +4 \\
\hline Kommunal/landsting & 47 & 30 & +17 \\
\hline \multicolumn{4}{|l|}{ Yrke $^{3}$} \\
\hline Arbetare & 22 & 47 & -25 \\
\hline Tjänsteman, lägre & 34 & 29 & +15 \\
\hline Tjänsteman, högre & 29 & 15 & +14 \\
\hline Jordbrukare & 4 & 1 & +3 \\
\hline Företagare & 12 & 8 & +4 \\
\hline \multicolumn{4}{|l|}{ Religiösa mötesbesök ${ }^{3}$} \\
\hline Aldrig & 35 & 53 & -18 \\
\hline Sällan & 42 & 37 & +5 \\
\hline Regelbundet & 22 & 10 & +12 \\
\hline \multicolumn{4}{|l|}{ Bosättningstid i kommunen ${ }^{3}$} \\
\hline 1 år och kortare & 1 & 4 & -3 \\
\hline $2-10$ år & 15 & 20 & -5 \\
\hline 10 år och längre & 84 & 76 & +8 \\
\hline \multicolumn{4}{|l|}{ Medborgarskap $^{4}$} \\
\hline Svenskt & 99 & 95 & +4 \\
\hline Utländskt & 1 & 5 & -4 \\
\hline \multicolumn{4}{|l|}{ Härkomst $^{5}$} \\
\hline Svensk & 88 & 81 & +7 \\
\hline Utländsk & 12 & 19 & -7 \\
\hline
\end{tabular}

Kommentar: Procentdifferensen beräknas genom att subtrahera procentandelen lokala politiker från procentandelen röstberättigad befolkning. Källor för uppgifter om röstberättigad befolkning: ${ }^{1} \mathrm{SCB}$ 1999a, s 57-58. ${ }^{2}$ Uppgifterna är hämtade dels från SCB 1999a, s 56 och SOM-undersökningen 1998 (Lithner 1999). ${ }^{3}$ SOM-undersökningen 1998 (Lithner 1999). ${ }^{4}$ SCB 1999a, s 80. ${ }^{5}$ SCB 1999b, s 60-65.

I tabell 17 redovisas andelen lokala politiker med utländskt medborgarskap. Det visade sig att personer med utländskt medborgarskap var underrepresenterade bland de lokala politikerna. I och för sig såg inte procentdifferensen så imponerande ut $(\mathrm{pd}=-4)$. Men det berodde på att den inte kunde överstiga 5 procentenheter. Den stora underrepresentationen framgick bättre av följande: Andelen lokala politiker med utländskt medborgarskap motsvarade en femtedel av andelen svenska invånare med utländskt medborgarskap. ${ }^{9}$ I tabell 17 redovisas att andelen med utländsk härkomst - både första och andra generationen med utländsk bakgrund - också var underrepresenterade $(\mathrm{pd}=-7)$. Andelen lokala 
politiker med utländsk härkomst motsvarade två tredjedelar av andelen svenska invånare med utländsk härkomst.

Tabell 17 Födelseland och härkomst med hänsyn till föräldragenerationen. En jämförelse mellan lokala politiker 1999 och befolkningen 1998 (procent och procentdifferens).

\begin{tabular}{lccccccc}
\hline & \multicolumn{3}{c}{$\begin{array}{c}\text { Eget } \\
\text { födelseland }\end{array}$} & \multicolumn{3}{c}{$\begin{array}{c}\text { Härkomst med hänsyn } \\
\text { till föräldragenerationen }\end{array}$} \\
\cline { 2 - 8 } Födelseland & $\begin{array}{c}\text { Lokala } \\
\text { politiker }\end{array}$ & $\begin{array}{c}\text { Befolk- } \\
\text { ning }\end{array}$ & $\begin{array}{c}\text { Procent- } \\
\text { differens }\end{array}$ & $\begin{array}{c}\text { Lokala } \\
\text { politiker }\end{array}$ & $\begin{array}{c}\text { Befolk- } \\
\text { ning }\end{array}$ & $\begin{array}{c}\text { Procent- } \\
\text { differens }\end{array}$ \\
\hline Sverige & 92,8 & 89,1 & $+3,7$ & 87,8 & 80,8 & $+7,0$ \\
Övriga Norden & 3,7 & 3,1 & $+0,6$ & 6,7 & 7,0 & $-0,3$ \\
Övriga Europa & 1,9 & 3,8 & $-1,9$ & 3,6 & 6,2 & $-2,6$ \\
Övriga världen & 1,6 & 4,0 & $-2,4$ & 1,9 & 6,0 & $-4,1$ \\
\hline Summa procent & 100 & 100 & & 100 & 100 & \\
Antal svarande & 1766 & & & 1769 & & \\
\hline Samtliga länder utanför Sverige & 7,2 & 10,9 & $-3,7$ & 12,2 & 19,2 & $-7,0$ \\
\hline
\end{tabular}

Kommentar: Källorna för uppgifter om befolkningen är hämtade ur SCB 1999b, s 60-65. Procentdifferensen beräknas genom att subtrahera procentandel befolkning från procentandel lokala politiker.

Första och andra generationen med utländsk bakgrund har aldrig varit en homogen grupp. Även på 1990-talet fanns stora skillnader beroende på individens eller föräldrarnas ursprungsland, hur länge vederbörande hade befunnit sig i Sverige och mycket annat. Vad som ska undersökas närmare är från vilken del av världen som de lokala politikerna med utländsk härkomst härstammade. I tabell 17 finns en sammanställning av andelen lokala politiker och svenska invånare som hade fötts i Sverige, övriga Norden, övriga Europa och övriga världen i slutet av 1990-talet. Dessutom redovisas motsvarande förhållanden vad gäller första och andra generationen med utländsk bakgrund, det vill säga härkomst med hänsyn till föräldragenerationen.

Etnisk bakgrund tycks ha haft stor betydelse för möjligheterna att delta i den lokala representativa demokratin på 1990-talet. Enligt tabell 17 hade dock den del av befolkningen som härstammade från de nordiska grannländerna en förhållandevis god representation bland de lokala politikerna (eget födelseland: $\mathrm{pd}=+0,6$; härkomst: $\mathrm{pd}=-0,5)$. Men personer som härstammade från icke- 
europeiska länder var kraftigt underrepresenterade bland de lokala politikerna. Andelen lokala politiker som fötts utanför Europa var inte ens hälften så stor som motsvarande andel $\mathrm{i}$ den svenska befolkningen $(\mathrm{pd}=-2,4)$. Tas även andra generationen med utländsk bakgrund från icke-europeiska länder med i beräkningarna visade det sig att representationen var än sämre. Andelen lokala politiker motsvarade då endast en tredjedel av första och andra generationen med utländsk bakgrund från icke-europeiska länder $(\mathrm{pd}=-4,1)$. Också personer från övriga Europa var underrepresenterade (eget födelseland: $\mathrm{pd}=-1,9$; härkomst: $\mathrm{pd}=-$ 2,6). Underrepresentationen av européer berodde dock helt på att personer från länder utanför EU hade en mycket låg representation, väl i klass med personer som härstammar från Asien och Afrika. Personer från länder utanför Norden och EU hade således mycket svårt att delta som kommunalt förtroendevald.

I kommunalpolitiken på 1990-talet fanns det grupper som var starkt underrepresenterade: unga, äldre, lågutbildade, arbetare, privatanställda, sekulariserade och personer med utländsk härkomst. Resultatet indikerade att en av demokratins grundläggande normer var svåra att upprätthålla: lika möjligheter till deltagande och inflytande.

\section{Parti}

Det var väljarna som röstade in de lokala politikerna i kommunfullmäktige. Men vilka individer som var lokala politiker berodde på partiernas interna nomineringsprocesser. De kandidater som väljarna röstade på till fullmäktige var rekryterade och nominerade av partierna. Ledamöter och suppleanter i kommunala nämnder röstade inte väljarna in, utan de utsågs av kommunfullmäktige. Det var således i stor utsträckning partierna själva som bestämde vilka egenskaper som de lokala politikerna hade 1999. I tabell 18 redovisas en jämförelse mellan den röstberättigade befolkningen och de lokala politikernas sociala bakgrund efter parti. Måttet är procentdifferens. I detta fall beräknas procentdifferensen genom att subtrahera procentandel röstberättigad befolkning från procentandel lokala politiker i respektive parti. När en grupp är överrepresenterad är differensen positiv, när en grupp är underrepresenterad är den negativ. En god representation innebär att procentdifferensen är noll eller nära noll. 
Det fanns stora skillnader mellan partierna vad gällde hur väl olika samhällsgrupper var representerade. Partierna skilde sig mycket åt vad gällde vilka utbildnings- och yrkesgrupper de representerade. Detta förhållande var inte överraskande. På väljarnivå var det sedan länge känt att förhållanden knutna till individens yrke hade starkt samband med val av parti (Holmberg 1981). Ett liknande samband stod att finna bland de lokala politikerna. Undantaget socialdemokraterna $(\mathrm{pd}=+5)$ och centerpartiet $(\mathrm{pd}=+6)$ var de högutbildade överrepresenterade i alla partier, främst i folkpartiet $(\mathrm{pd}=+37)$.

Tabell 18 Olika samhällsgruppers deltagande i den lokala representativa demokratin, efter parti. Vilka samhällsgrupper är över- respektive underrepresenterade? En jämförelse mellan lokala politiker 1999 och den röstberättigade befolkningen 1998 (procentdifferens).

\begin{tabular}{|c|c|c|c|c|c|c|c|c|}
\hline \multirow[b]{2}{*}{ Kön ${ }^{1}$} & \multicolumn{8}{|c|}{ Parti } \\
\hline & $v$ & $s$ & $m p$ & $c$ & $f p$ & $k d$ & $m$ & $\overline{\text { övriga }}$ \\
\hline Män & -1 & +4 & +5 & +10 & -11 & +12 & +15 & +10 \\
\hline Kvinnor & +1 & -4 & -5 & -10 & +11 & -12 & -15 & -10 \\
\hline \multicolumn{9}{|l|}{ Ålder ${ }^{1}$} \\
\hline $18-29 \stackrel{a}{a} r$ & -11 & -12 & -15 & -13 & -15 & -11 & -13 & -14 \\
\hline $30-44 \stackrel{a}{a} r$ & -4 & -6 & +2 & -8 & -4 & -6 & -6 & -11 \\
\hline $45-54$ & +15 & +14 & +19 & +17 & +11 & +15 & +7 & +6 \\
\hline $55-66 \stackrel{\circ}{a} r$ & +8 & +18 & +8 & +18 & +18 & +15 & +22 & +17 \\
\hline 67-år & -17 & -14 & -14 & -14 & -10 & -12 & -9 & +2 \\
\hline \multicolumn{9}{|l|}{ Civilstånd $^{2}$} \\
\hline Ensamstående & +4 & +2 & +9 & 0 & 0 & -2 & 0 & +2 \\
\hline Gift/sambo & 0 & +6 & -8 & +12 & +15 & +16 & +8 & -1 \\
\hline Frånskild & +3 & -3 & +6 & -9 & -8 & -8 & -6 & +5 \\
\hline Änka/änkeman & -6 & -6 & -7 & -4 & -7 & -7 & -3 & -6 \\
\hline \multicolumn{9}{|l|}{ Utbildningsnivå $^{3}$} \\
\hline Låg & -25 & -7 & -32 & -13 & -38 & -27 & -34 & -20 \\
\hline Medel & 0 & +2 & -7 & +7 & 0 & -2 & +2 & -1 \\
\hline Hög & +26 & +5 & +39 & +6 & +37 & +29 & +32 & +21 \\
\hline \multicolumn{9}{|l|}{ Typ av anställning 3} \\
\hline Heltidsanställd & +10 & +15 & +1 & -9 & +11 & +8 & 0 & -13 \\
\hline Deltidsanställd & +1 & -5 & 0 & +4 & -2 & +2 & -5 & -2 \\
\hline Pensionär & -14 & -10 & -16 & -10 & -7 & -7 & -2 & +5 \\
\hline Studerande & -2 & -5 & -4 & -3 & -8 & -6 & -4 & -4 \\
\hline Arbetslös & -1 & +1 & +3 & -1 & -4 & -4 & -3 & 0 \\
\hline Annat & +5 & +4 & +16 & +19 & +9 & +8 & +15 & +14 \\
\hline
\end{tabular}


Tabell 18 forts.

\begin{tabular}{|c|c|c|c|c|c|c|c|c|}
\hline \multicolumn{9}{|l|}{ Anställningssektor ${ }^{3}$} \\
\hline Privat & -21 & -16 & -33 & -8 & -6 & -16 & +1 & -6 \\
\hline Statlig & +4 & +4 & +12 & +1 & -3 & +2 & +5 & +11 \\
\hline Kommunal/landsting & +17 & +16 & +21 & +7 & +9 & +14 & -6 & -5 \\
\hline \multicolumn{9}{|l|}{ Yrke $^{3}$} \\
\hline Arbetare & -21 & -10 & -24 & -28 & -39 & -27 & -42 & -28 \\
\hline Tjänsteman, lägre & +16 & +3 & +21 & -5 & +6 & +10 & +2 & 0 \\
\hline Tjänsteman, högre & +11 & +11 & +4 & +7 & +24 & +13 & +21 & +4 \\
\hline Jordbrukare & 0 & 0 & +2 & +19 & +1 & +1 & +5 & +3 \\
\hline Företagare & -5 & -4 & -3 & +7 & +9 & +3 & +15 & +21 \\
\hline \multicolumn{9}{|l|}{ Religiösa mötesbesök ${ }^{3}$} \\
\hline Aldrig & +12 & -10 & +4 & -41 & -26 & -49 & -24 & +2 \\
\hline Sällan & -6 & +9 & -4 & +22 & +3 & -22 & +12 & -1 \\
\hline Regelbundet & -6 & +1 & 0 & +19 & +24 & +70 & +13 & -1 \\
\hline \multicolumn{9}{|l|}{ Bosättningstid i kommunen ${ }^{3}$} \\
\hline 1 år och kortare & -3 & -3 & -4 & -2 & -4 & -3 & -3 & -4 \\
\hline $2-10 a ̊ r$ & +8 & -10 & +2 & -12 & 0 & +4 & -4 & -11 \\
\hline 10 år och längre & -5 & +13 & +2 & +14 & -4 & -2 & +7 & +15 \\
\hline \multicolumn{9}{|l|}{ Medborgarskap ${ }^{4}$} \\
\hline Svenskt & +3 & +4 & 0 & +5 & +5 & +2 & +4 & +3 \\
\hline Utländskt & -3 & -4 & 0 & -5 & -5 & -2 & -4 & -3 \\
\hline \multicolumn{9}{|l|}{ Härkomst ${ }^{5}$} \\
\hline Svensk & -1 & +7 & +1 & +13 & +10 & +8 & +8 & +7 \\
\hline Utländsk & +1 & -7 & -1 & -13 & -10 & -8 & -8 & -7 \\
\hline
\end{tabular}

Kommentar: Procentdifferensen beräknas genom att subtrahera procentandelen lokala politiker från procentandelen röstberättigad befolkning. Källor för uppgifter om röstberättigad befolkning: ${ }^{1} \mathrm{SCB}$ 1999a, s 57-58. 2Uppgifterna är hämtade dels från SCB 1999a, s 56 och SOM-undersökningen 1998 (Lithner 1999). ${ }^{3}$ SOM-undersökningen 1998 (Lithner 1999). ${ }^{4}$ SCB 1999a, s 80. ${ }^{5}$ SCB 1999b, s 60-65.

Socialdemokraterna var också det parti där arbetarna var minst underrepresenterade $(\mathrm{pd}=-10)$. Bland moderater $(\mathrm{pd}=-42)$ och folkpartister $(\mathrm{pd}=-$ 39) var arbetarna extra mycket underrepresenterade. Bland dessa var istället högre tjänstemän mycket överrepresenterade ( $\mathrm{fp}$ : $\mathrm{pd}=+24$; $\mathrm{m}$ : $\mathrm{pd}=+21$ ). Jordbrukarna var extremt överrepresenterade bland centerpartisterna $(\mathrm{pd}=+19)$. Med tanke på att endast 1 procent av befolkningen var jordbrukare innebar det att andelen centerpartistiska jordbrukare var tjugo gånger fler bland de lokala politikerna än $i$ den svenska befolkningen. Medan centerpartiet, folkpartiet och moderaterna hade en tämligen god representation av de olika anställningssektorerna, var andelen kommunal- och landstingsanställda överrepresenterade bland miljöpartisterna 
$(\mathrm{pd}=+21)$, vänsterpartisterna $(\mathrm{pd}=+17), \quad$ socialdemokraterna $(\mathrm{pd}=+16)$ och kristdemokratern $(\mathrm{pd}=+12)$.

På väljarnivå var religiositet en betydande förklaringsfaktor till varför väljarna röstade som de gjorde. Jämfört med socioekonomiska faktorer brukade religiositet rankas som näst bästa förklaringsfaktor efter yrke (Holmberg \& Gilljam 1987; Hagevi 2009). Bland lokala politiker var regelbundna besökare av religiösa möten starkt överrepresenterade bland kristdemokraterna. Åtta av tio kristdemokrater besökte religiösa möten regelbundet $(\mathrm{pd}=+70)$. Även bland folkpartisterna $(\mathrm{pd}=+24)$ och centerpartisterna $(\mathrm{pd}=+19)$ var de regelbundna mötesbesökarna överrepresenterade, men inte i närheten av kristdemokraterna proportioner. Både bland kristdemokraterna $(\mathrm{pd}=-49)$ och centerpartisterna $(\mathrm{pd}=-41)$ fanns det mycket få som aldrig besöker religiösa möten.

Kvinnor och män (Dahlerup 1988) hade en förhållandevis jämn representation bland vänsterpartisterna $(\mathrm{pd}= \pm 1), \quad$ socialdemokraterna $\quad(\mathrm{pd}= \pm 4) \quad$ och miljöpartisterna $(\mathrm{pd}= \pm 5)$, men mer ojämn bland de borgerliga partierna, framförallt moderaterna $(\mathrm{pd}= \pm 15)$. Gifta och samboende var överrepresenterade bland kristdemokrater $(\mathrm{pd}=+16)$, folkpartister $(\mathrm{pd}=+15)$ och centerpartister $(\mathrm{pd}=+12)$, medan frånskilda var något överrepresenterade bland miljöpartisterna $(\mathrm{pd}=+6)$.

Personer med utländsk härkomst var underrepresenterade $\mathrm{i}$ alla partier utom i vänsterpartiet $(\mathrm{pd}=+1)$ och miljöpartiet $(\mathrm{pd}=-1)$. Utländska medborgare var också underrepresenterade $\mathrm{i}$ de flesta partier, undantaget miljöpartiet $(\mathrm{pd}=0)$. Bland moderater $(\mathrm{pd}=-2)$ och vänsterpartister $(\mathrm{pd}=-3)$ fanns en relativt liten underrepresentation av utländska medborgare. Bland centerpartisterna och folkpartisterna var utländska medborgarna (båda $\mathrm{pd=-5}$ ) och personer med utländsk härkomst (c: $\mathrm{pd}=-13$; $\mathrm{fp}$ : $\mathrm{pd}=-10$ ) underrepresenterade $\mathrm{i}$ särskild stor utsträckning.

Efter en genomgång av över- och underrepresenterade grupper i de olika partierna var det möjligt att konstatera att det fanns klara variationer mellan partierna. 


\section{Typer av deltagande i den lokala representativa demokratin}

En lokal politiker har möjlighet att medverka i olika typer av deltagande. Politiska uppdrag i kommunstyrelse, presidieuppdrag i kommunala nämnder och om politikerna har många uppdrag sätts ofta i samband med inflytande. Sådana politiska uppdrag är maktpositioner (Hagevi 2000). Det är skillnad att vara ordförande $\mathrm{i}$ en nämnd i jämförelse med att vara ledamot eller suppleant. Det är också skillnad mellan att sitta i kommunstyrelsen - maktens centrum - och att vara ledamot i en vanlig nämnd. Likaså kan omfattningen på deltagandet skilja sig: somliga har ett uppdrag, andra har flera. Även om det finns flera andra typer av deltagande i den lokala representativa demokratin är avsikten att undersöka dessa tre lite närmare. Antagligen är det svårare för en individ att uppnå en maktposition och få delta i till exempel kommunstyrelsen än i en vanlig nämnd. Vilka samhällsgrupper var över- respektive underrepresenterade bland presidieledamöterna, i kommunstyrelserna och bland politiker med två eller flera uppdrag 1999 (se tabell 19)?

Skillnaderna i över- och underrepresentation beroende på typ av kommunalt uppdrag tenderade att vara små. Men när det gällde maktpositioner kunde en viss tendens till förstärkta skillnader mellan under- och överrepresenterade grupper dock skönjas.

Kvinnor tenderade att vara mer underrepresenterade högre upp i makthierarkin: procentdifferensen för kvinnor var mer negativ i presidier $(\mathrm{pd}=-14)$ och kommunstyrelse $(\mathrm{pd}=-12)$ än för samtliga lokala politiker $(\mathrm{pd}=-8)$. Det var dock möjligt att notera att det var förhållandevis stor andel kvinnor som hade två eller fler uppdrag. Det resulterade i att kvinnor var ungefär lika underrepresenterade bland lokala politiker med två eller fler uppdrag $(\mathrm{pd}=-7)$ som bland samtliga lokalpolitiker $(\mathrm{pd}=-8)$.

Lokala politiker i övre medelåldern (55-66 år) var extra mycket överrepresenterade bland presidieledamöterna $(\mathrm{pd}=+29)$. Pensionärerna var däremot extra mycket underrepresenterade i kommunstyrelserna $(\mathrm{pd}=-12)$.

Presidieledamöter tenderade att vara mer religiöst aktiva $(\mathrm{pd}=+25)$ och hade ofta varit bosatta $\mathrm{i}$ kommunen längre $(\mathrm{pd}=+15)$ än andra lokala politiker. Dessa 
samband förklarades till stor del med att politisk erfarenhet hade relativ stor betydelse när presidieledamöter utsågs (se nedan).

Tabell 19 Jämförelse mellan olika typer av deltagande: presidieledamöter, ledamöter och suppleanter i kommunstyrelse samt politiker med två eller fler uppdrag. Vilka samhällsgrupper var över- respektive underrepresenterade? Procentdifferens mellan lokala politiker 1999 och den röstberättigade befolkningen 1998.

\begin{tabular}{|c|c|c|c|c|}
\hline Kön ${ }^{1}$ & $\begin{array}{c}\text { Presidie- } \\
\text { ledamöter i } \\
\text { kommunal } \\
\text { nämnd }\end{array}$ & $\begin{array}{c}\text { Ledamöter } \\
\text { och suppleanter } \\
\text { i kommunstyrelse }\end{array}$ & $\begin{array}{l}\text { Lokala politiker } \\
\text { med två upp- } \\
\text { drag eller fler }\end{array}$ & $\begin{array}{c}\text { Samtliga } \\
\text { lokala } \\
\text { politiker }\end{array}$ \\
\hline Män & +14 & +12 & +7 & +8 \\
\hline Kvinnor & -14 & -12 & -7 & -8 \\
\hline \multicolumn{5}{|l|}{ Ålder ${ }^{1}$} \\
\hline $18-29 a ̊ r$ & -16 & -15 & -14 & -13 \\
\hline $30-44$ år & -12 & -7 & -7 & -6 \\
\hline $45-54$ & +12 & +19 & +14 & +14 \\
\hline $55-66 \stackrel{\circ}{a} r$ & +29 & +20 & +20 & +17 \\
\hline $67-\stackrel{a}{a} r$ & -13 & -17 & -13 & -12 \\
\hline \multicolumn{5}{|l|}{ Civilstånd ${ }^{2}$} \\
\hline Ensamstående & -2 & 0 & 0 & +1 \\
\hline Gift/sambo & +12 & +10 & +7 & +7 \\
\hline Frånskild & -5 & -6 & -3 & -3 \\
\hline Änka/änkeman & -5 & -5 & -5 & -5 \\
\hline \multicolumn{5}{|l|}{ Utbildningsnivå $^{3}$} \\
\hline Låg & -20 & -20 & -20 & -21 \\
\hline Medel & +1 & +2 & +1 & +1 \\
\hline Hög & +18 & +18 & +19 & +20 \\
\hline \multicolumn{5}{|l|}{ Typ av anställning ${ }^{3}$} \\
\hline Heltidsanställd & +6 & +8 & +3 & +7 \\
\hline Deltidsanställd & -3 & -2 & -2 & -3 \\
\hline Pensionär & -9 & -12 & -7 & -8 \\
\hline Studerande & -6 & -6 & -5 & -5 \\
\hline Arbetslös & -1 & -3 & -1 & -1 \\
\hline Annat & +14 & +14 & +12 & +10 \\
\hline \multicolumn{5}{|l|}{ Anställningssektor ${ }^{3}$} \\
\hline Privat & -9 & -14 & -11 & -21 \\
\hline Statlig & +5 & +6 & +4 & +4 \\
\hline Kommunal/landsting & +4 & +8 & +7 & +17 \\
\hline
\end{tabular}


Tabell 19 forts.

Yrke $^{3}$

\begin{tabular}{|c|c|c|c|c|}
\hline Arbetare & -31 & -27 & -27 & -25 \\
\hline Tjänsteman, lägre & +6 & +5 & +5 & +15 \\
\hline Tjänsteman, högre & +18 & +14 & +13 & \\
\hline Jordbrukare & +4 & +5 & +3 & \\
\hline Företagare & +3 & +3 & +3 & \\
\hline \multicolumn{5}{|l|}{ iösa mötesbesök ${ }^{3}$} \\
\hline Aldrig & -34 & -17 & -16 & \\
\hline Sällan & +9 & +9 & +4 & \\
\hline $\begin{array}{l}\text { Regelbundet } \\
\text { tningstid i komm }\end{array}$ & +25 & +9 & +12 & \\
\hline 1 år och kortare & -4 & -2 & -3 & - \\
\hline $2-10$ år & -11 & -6 & -5 & \\
\hline $\begin{array}{l}10 \text { år och längre } \\
\text { orgarskap }^{4}\end{array}$ & +15 & +8 & +8 & \\
\hline Svenskt & +4 & +4 & +4 & +4 \\
\hline Utländskt & -4 & -4 & -4 & \\
\hline \multicolumn{5}{|l|}{ omst $^{5}$} \\
\hline Svensk & +11 & +13 & +9 & +7 \\
\hline Utländsk & -11 & -13 & -9 & \\
\hline
\end{tabular}

Kommentar: Procentdifferensen beräknas genom att subtrahera procentandelen lokala politiker från procentandelen röstberättigad befolkning. Källor för uppgifter om röstberättigad befolkning: ${ }^{1} \mathrm{SCB}$ 1999a, s 57-58. ²Uppgifterna är hämtade dels från SCB 1999a, s 56 och SOM-undersökningen 1998 (Lithner 1999). ${ }^{3}$ SOM-undersökningen 1998 (Lithner 1999). ${ }^{4}$ SCB 1999a, s 80. ${ }^{5}$ SCB 1999b, s 60-65.

Enligt tabell 19 var utländska medborgare samt första och andra generationen med utländsk bakgrund ungefär lika underrepresenterade oavsett vilken typ av kommunalt deltagande som undersöktes.

Anställda inom den privata sektorn var generellt underrepresenterade och kommunal- och landstingsanställda generellt överrepresenterade bland lokala politiker. Anställda i privata sektorn tenderade dock att vara mindre underrepresenterade och kommunal- och landstingsanställda mindre överrepresenterade när typen av deltagande gällde presidium, kommunstyrelse eller innehav av två eller flera uppdrag. Lägre tjänstemän tenderade även de att bli mindre överrepresenterade när typen av deltagande gällde presidium $(\mathrm{pd}=+6)$, kommunstyrelse $(\mathrm{pd}=+5)$ eller innehav av två eller flera uppdrag $(\mathrm{pd}=+5)$. Det 
samma gällde dock inte högre tjänstemän som istället höll ställningarna och var fortsatt överrepresenterade.

Bland de lokala politikerna fanns det stora skillnader beträffande olika samhällsgruppers representation. Bland de mest underrepresenterade grupperna fanns personer med utländsk härkomst, unga under 30 år, de som var 67 år och äldre, lågutbildade, arbetare och personer som arbetade i privat sektor. Bland de mest överrepresenterade grupperna fanns personer i övre medelåldern, högutbildade, tjänstemän, kommunal- och landstingsanställda, religiösa mötesbesökare. Alltjämt var kvinnor något underrepresenterade, men vid en jämförelse med tidigare undersökningar (Kommunalt förtroendevalda 1995 1996) hade kvinnors underrepresentation minskat 1999. Vid en separat undersökning av maktpositioner visade det sig att de nu uppräknade gruppernas under- respektive överrepresentation tenderade att till viss del skärpas. Ett undantag var dock anställningssektor där privatanställdas underrepresentation tenderade att minska när maktpositionerna undersöktes.

\section{Lokala politiker som kanaler ut i samhället: föreningsaktivitet}

Förtroendevalda bör hålla kontakt med övriga medborgare och fungera som kanaler ut i samhället - detta är något som inte bara anhängare av deltagaridealet framhäver. Sådana kontakter kan ske på många sätt. Vad anhängarna av deltagaridealet ofta framhäver är att kanalerna måste vara många och vitt förgrenade så att de når ut till samtliga grupper i samhället. Men kontakter mellan väljare och valda kan också vara kanaler in i politiken. En samhällsaktör med goda kontakter kan med hjälp av dessa påverka både politiker och beslut.

Enligt deltagaridealets anhängare maximeras kontakterna och antalet kanaler genom att så många medborgare som möjligt innehar eller har innehaft politiska uppdrag. I vårt land innehas de flesta politiska förtroendeuppdrag av lokala politiker. En intressant fråga är därför i vilken omfattning de lokala politikerna hade kontakter med olika grupper i samhället i slutet av 1990-talet (se Brothén \& Gilljam 2006). Kunde man säga att de lokala politikerna fungerade som kanaler mellan väljare och valda? I det följande kommer tre indikatorer på kontakt mellan lokala politiker och olika samhällsaktörer att analyseras: de lokala politikernas 
egen föreningsaktivitet; de lokala politikernas egna kontakter med olika samhällsaktörer, och publiceringsfrekvens i dagstidningar.

Samtliga av de uppgifter som kommer att redovisas om föreningsaktivitet, publiceringsfrekvens och kontakter med olika samhällsaktörer bygger på de lokalpolitikernas egna uppgifter. Att tolka självrapporterade uppgifter kan vara vanskligt. Det är en grundläggande källkritisk dygd att vara försiktig med att översätta självrapporterade uppgifter om det egna beteendet till faktiska förhållanden. Risken för att rapportörerna överdriver det positiva och förtiger det negativa befaras vanligen vara tämligen stort (Esaiasson och Holmberg 1996). Därför är det lämpligt att ta självrapporterade uppgifter om det egna beteendet med en nypa salt vad gäller de absoluta nivåerna. Däremot ökar möjligheterna att dra slutsatser om skillnader mellan olika grupper. Utifrån antagandet att alla drar ifrån och lägger till i ungefär lika stor utsträckning, bör skillnader mellan olika undersökningskategorier - till exempel mellan partierna - ha relativt god validitet.

Låt oss börja med de lokala politikernas föreningsaktivitet. Genom att själva ha varit föreningsaktiva utanför det egna partiets hank och stör kunde de lokala politikerna komma i kontakt med relativt många väljare. Kontakterna blev antagligen både fler och fördjupade om engagemanget ledde till formella uppdrag i föreningen eller $\mathrm{i}$ organisationen. I tabell 20 redovisas de lokala politikernas självrapporterade medlemskap och uppdrag i åtta olika kategorier av föreningar, vilket även jämförs med motsvarande förhållande bland den röstberättigade befolkningen. Genom att beräkna procentdifferensen (skillanden mellan lokala politiker och röstberättigad befolkning) är det även möjligt att undersöka om de lokala politikerna var mer föreningsaktiva än befolkningen i övrigt.

Det verkar som om de lokala politikerna enligt sina egna uppgifter var något mer föreningsaktiva än befolkningen i övrigt 1999. I de flesta föreningskategorier var det ungefär 10-15 procentenheter vanligare att lokala politiker uppgav sig vara medlemmar jämfört med den övriga befolkningen. 
Tabell 20 De lokala politikernas medlemskap och uppdrag i åtta olika kategorier av föreningar $1999 \mathrm{i}$ jämförelse med den röstberättigade befolkningen 1998 (procent och procentdifferens).

\begin{tabular}{|c|c|c|c|}
\hline $\begin{array}{l}\text { Kategori av } \\
\text { förening/organisation }\end{array}$ & $\begin{array}{c}\text { Lokala } \\
\text { politiker }\end{array}$ & $\begin{array}{c}\text { Röstberättigad } \\
\text { befolkning }\end{array}$ & Procentdifferens \\
\hline \multicolumn{4}{|c|}{ Idrotts- eller friluftsförening } \\
\hline Medlem & 46 & 35 & +11 \\
\hline Medlem med uppdrag & 13 & 11 & +2 \\
\hline \multicolumn{4}{|l|}{ Miljöorganisation } \\
\hline Medlem & 18 & 6 & +12 \\
\hline Medlem med uppdrag & 1 & 1 & 0 \\
\hline \multicolumn{4}{|l|}{ Fackförening } \\
\hline Medlem & 72 & 57 & +15 \\
\hline Medlem med uppdrag & 15 & 6 & +9 \\
\hline \multicolumn{4}{|c|}{$\begin{array}{l}\text { Hyresgästsförening, bostadsrätt- } \\
\text { eller villaägarförening }\end{array}$} \\
\hline Medlem & 40 & 36 & +4 \\
\hline Medlem med uppdrag & 8 & 4 & +4 \\
\hline \multicolumn{4}{|c|}{ Kulturförening, musik, dans etc. } \\
\hline Medlem & 32 & 15 & +17 \\
\hline Medlem med uppdrag & 8 & 4 & +4 \\
\hline \multicolumn{4}{|l|}{ Pensionärsförening } \\
\hline Medlem & 11 & 12 & -1 \\
\hline Medlem med uppdrag & 3 & 2 & +1 \\
\hline \multicolumn{4}{|l|}{ Svenska kyrkan } \\
\hline Medlem & - & 85 & \\
\hline Medlem med uppdrag & 10 & 2 & +8 \\
\hline \multicolumn{4}{|l|}{ Annat religiöst samfund } \\
\hline \multicolumn{4}{|l|}{ än Svenska kyrkan } \\
\hline Medlem & 11 & 6 & +5 \\
\hline Medlem med uppdrag & 6 & 3 & +3 \\
\hline
\end{tabular}

Kommentar: Procentdifferensen beräknades genom att subtrahera procentandelen lokala politiker från procentandelen röstberättigad befolkning. Källan för uppgifterna om röstberättigad befolkning var SOM-undersökningen 1998 (Lithner 1999). I postenkätundersökningen "Kommunalt förtroendevalda 1999" tillfrågades inte de lokala politikerna om eventuellt medlemskap i Svenska kyrkan.

I många föreningskategorier var det dubbelt så vanligt att lokala politiker rapporterade att de innehade någon form av uppdrag än $\mathrm{i}$ befolkningen $\mathrm{i}$ övrigt. I organisationer som stod nära politiken var det betydligt vanligare att lokala politiker rapporterade innehav av uppdrag. Var sjätte lokal politiker uppgav att de hade uppdrag i fackförening. Av dessa var 10 procentenheter socialdemokrater och 2 procentenheter vänsterpartister. I slutet av 1990-talet var många av 
ledamöterna i kyrkofullmäktige en representant för ett politiskt parti som också fanns i riksdagen. Flera av dessa var också aktiva inom kommunalpolitiken. Var tionde lokalpolitiker uppgav sig ha uppdrag i någon av Svenska kyrkans organisationer. I några föreningskategorier var skillnaden mellan de lokala politikerna och den övriga befolkningen i andelen uppdrag inte så stor. Det var ungefär lika vanligt att lokala politiker uppgav sig ha uppdrag i idrotts- eller friluftsförening, miljöorganisation och pensionärsorganisation som bland befolkningen i övrigt.

I jämförelse med befolkningen i övrigt tycktes de lokala politikerna vara en tämligen föreningsaktiv grupp. Stämde de självrapporterade uppgifterna överens med verkligheten hade således de lokala politikerna relativt goda möjligheter till kontakter med andra medborgare i Föreningssverige.

\section{Lokala politiker som kanaler ut i samhället: kontaktnät}

En lokal politiker måste inte ha varit föreningsmedlem för att ha haft god väljarkontakt. Politiker kan odla kontakter vid sidan av personliga medlemskap. Det fanns även flera andra samhällsaktörer som lokala politiker kunde ha kontakt med. I tabell 21 redovisas andelen lokala politiker som i egenskap av att vara kommunalt förtroendevald varit i kontakt med 28 olika samhällsaktörer i slutet av 1990-talet. Sammanställningen redovisar samtligas svar och dessutom politikernas svar efter parti. Längst ut till höger $\mathrm{i}$ tabell 21 redovisas även den maximala skillnaden mellan partierna i rapporterade kontakter med respektive aktör och mellan vilka partier skillnaden var som störst.

Låt oss till att börja kommentera kontaktfrekvensen bland samtliga lokala politiker. Deras vanligaste kontakt var enligt dem själva med enskilda väljare. Därnäst kom politiker på regional och nationell nivå: landstingspolitiker och riksdagsledamöter. De lokala politikerna uppgav sig även tämligen ofta ha kontakt med andra aktörer som hade stark koppling till politiken: fackföreningar, ungdomsorganisationer och i vissa fall kvinnoorganisationer (alla partier hade egna ungdomsorganisationer och de flesta hade kvinnoorganisationer). De självrapporterade kontakterna med statsråd var betydligt mer sparsamma och beroende av vilket parti som var i regeringsställning. 
Tabell 21 Lokala politikers självrapporterade kontakter med 28 samhällsaktörer 1999. Andel som uppger sig haft kontakt minst flera gånger det senaste året, efter parti och samtliga (procent och maximal skillnad mellan partierna).

\begin{tabular}{|c|c|c|c|c|c|c|c|c|c|c|c|}
\hline \multirow[b]{2}{*}{ Aktör } & \multicolumn{8}{|c|}{ Parti } & \multirow[b]{2}{*}{ samtliga } & \multirow{2}{*}{\multicolumn{2}{|c|}{ maximal skillnad }} \\
\hline & $v$ & $s$ & $m p$ & c & $f p$ & $k d$ & $m$ & övr. & & & \\
\hline Enskilda väljare & 83 & 82 & 72 & 85 & 76 & 79 & 86 & 82 & 82 & \pm 14 & $\mathrm{~m}-\mathrm{mp}$ \\
\hline Landstingspolitiker & 62 & 59 & 48 & 54 & 57 & 60 & 58 & 16 & 57 & \pm 14 & $\mathrm{v}-\mathrm{mp}$ \\
\hline Riksdagsledamöter & 54 & 49 & 34 & 39 & 36 & 48 & 45 & 6 & 45 & \pm 20 & $\mathrm{v}$-mp \\
\hline Lokala företagare & 28 & 41 & 27 & 59 & 45 & 42 & 55 & 40 & 44 & \pm 32 & c-mp \\
\hline Lokal intresseorganisation & 38 & 39 & 38 & 56 & 28 & 35 & 37 & 37 & 39 & \pm 28 & c-fp \\
\hline Facklig organisation & 41 & 55 & 15 & 23 & 21 & 16 & 20 & 20 & 34 & \pm 35 & $\mathrm{~s}-\mathrm{m}$ \\
\hline Idrottsförening & 29 & 36 & 18 & 43 & 29 & 28 & 31 & 30 & 33 & \pm 25 & c-mp \\
\hline Kulturförening & 34 & 34 & 29 & 39 & 30 & 31 & 28 & 30 & 32 & \pm 11 & $c-m$ \\
\hline Ungdomsorganisation & 34 & 32 & 14 & 32 & 26 & 31 & 28 & 27 & 30 & \pm 20 & $\mathrm{v}$-mp \\
\hline Föräldraförening & 36 & 26 & 22 & 26 & 25 & 30 & 32 & 20 & 28 & \pm 14 & $\mathrm{v}-\mathrm{mp}$ \\
\hline Pensionärsorganisation & 22 & 32 & 12 & 28 & 25 & 24 & 25 & 27 & 27 & \pm 20 & s-mp \\
\hline Lokala statliga myndigheter & 20 & 28 & 15 & 31 & 20 & 14 & 26 & 19 & 24 & \pm 17 & $\mathrm{c}-\mathrm{kd}$ \\
\hline Svenska kyrkan & 8 & 18 & 4 & 39 & 25 & 39 & 29 & 6 & 23 & \pm 35 & c-mp \\
\hline Bostadsorganisation & 32 & 28 & 21 & 11 & 16 & 10 & 23 & 22 & 22 & \pm 22 & $\mathrm{v}-\mathrm{m}$ \\
\hline Kvinnoorganisation & 26 & 28 & 11 & 37 & 12 & 11 & 12 & 0 & 21 & \pm 26 & $\mathrm{c}-\mathrm{m} / \mathrm{mp}$ \\
\hline Miljöorganisation & 27 & 18 & 56 & 16 & 10 & 12 & 13 & 23 & 19 & \pm 46 & mp-fp \\
\hline Företagsorganisation & 12 & 17 & 9 & 24 & 19 & 18 & 26 & 19 & 19 & \pm 17 & m-mp \\
\hline Andra svenska företagare & 6 & 14 & 10 & 24 & 13 & 19 & 27 & 18 & 18 & \pm 21 & $\mathrm{~m}-\mathrm{v}$ \\
\hline Utländska företagare & 0 & 3 & 1 & 7 & 5 & 6 & 9 & 6 & 17 & \pm 7 & $c-v$ \\
\hline Centrala statliga myndigheter & 16 & 17 & 13 & 16 & 7 & 12 & 14 & 14 & 15 & \pm 10 & s-fp \\
\hline Invandrarorganisation & 27 & 17 & 12 & 5 & 14 & 12 & 10 & 8 & 14 & \pm 22 & $\mathrm{v}-\mathrm{c}$ \\
\hline \multicolumn{12}{|l|}{ Annat religiöst samfund än } \\
\hline Svenska kyrkan & 5 & 6 & 5 & 15 & 17 & 51 & 10 & 4 & 13 & \pm 46 & $\mathrm{kd}-\mathrm{v} / \mathrm{mp}$ \\
\hline Konsumentförening/KF & 13 & 24 & 8 & 9 & 0 & 4 & 4 & 4 & 12 & \pm 24 & s-fp \\
\hline Arbetsgivarorganisation & 8 & 9 & 1 & 10 & 9 & 8 & 14 & 0 & 9 & \pm 13 & $\mathrm{~m}-\mathrm{mp}$ \\
\hline Regeringstjänstemän & 7 & 14 & 8 & 7 & 5 & 8 & 6 & 4 & 9 & \pm 9 & s-fp \\
\hline Jordbruksorganisation & 1 & 4 & 4 & 36 & 3 & 4 & 6 & 2 & 7 & \pm 35 & $c-v$ \\
\hline Statsråd & 1 & 12 & 1 & 3 & 1 & 3 & 3 & 2 & 6 & \pm 15 & s-fp/mp/v \\
\hline EU-myndigheter & 5 & 4 & 1 & 7 & 5 & 2 & 5 & 0 & 4 & \pm 6 & $\mathrm{c}-\mathrm{mp}$ \\
\hline
\end{tabular}

Kommentar: Den exakta frågeformuleringen löd som följer. "Den har frågan gäller Dina kontakter som kommunalt förtroendevald med olika organisationer, grupper, föreningar och andra aktörer. Oavsett hur kontakten togs, hur ofta har Du under det senaste året haft skriftliga eller muntliga kontakter med nedanstående aktörer?". Därefter nämndes de 28 aktörerna. För var och en av aktörerna kunde de lokala politikerna uppge att de haft kontakt "Minst en gång i månaden", "Flera gånger det senaste året", "Någon enstaka gång det senaste året" eller "Aldrig". 
De lokala politikerna rapporterade också tämligen omfattande kontakter med aktörer som tillhörde det "civila samhället": lokala intresseorganisationer, idrottsföreningar, kulturföreningar, föräldraföreningar och pensionärsorganisationer.

Vad gällde näringslivet skiftade den självrapporterade kontaktfrekvensen beroende av vilken aktör som kontakten gällde. Många lokala politiker uppgav sig ha goda kontakter med lokala företagare. Däremot var det inte lika vanligt att rapportera goda kontakter med andra svenska och utländska företag samt företagsorganisationer.

Jämfört med andra aktörer (Esaiasson \& Holmberg 1996) rapporterade de lokala politikerna relativt sparsamma kontakter med statliga myndigheter. De statliga myndigheter som de oftast rapporterade ha kontakt med var lokala, medan kontakter med centrala statliga myndigheter eller regeringstjänstemän var mer sällsynta.

I tabell 21 redovisades även skillnader mellan partierna. Resultatet präglades i hög grad av partiernas egen inriktning. Ordstävet "säg mig vem du umgås med och jag kan tala om vem du är" tycks ha varit tillämpligt på de lokala politikerna i slutet av 1990-talet. Den största skillnaden mellan två partier gällde kontakterna med miljöorganisationer och annat religiöst samfund än Svenska kyrkan. I det första fallet var miljöpartisternas självrapporterade kontakter med miljöorganisationer exceptionellt täta, medan folkpartisternas kontakter var ganska glesa. I det andra fallet var kristdemokraternas självrapporterade kontakter med annat religiöst samfund än Svenska kyrkan oerhört mycket mer omfattande än vad som var fallet för vänsterpartisterna och miljöpartisterna samt även socialdemokraterna. Även om skillnaderna mellan partierna inte var lika extrema beträffande självrapporterade kontakter med organisationer inom Svenska kyrkan var de stora. Centerpartister och kristdemokrater uppgav sig ha betydligt fler kontakter med Svenska kyrkans organisationer än framförallt miljöpartisterna men också vänsterpartisterna. Centerpartisterna hade en särställning vad gällde kontakterna med jordbruksorganisationer. Socialdemokraterna och vänsterpartisterna rapporterade täta kontakter med företrädare för fackliga organisationer. Miljöpartisterna och vänsterpartisterna uppgav inte lika ofta att de hade kontakt med lokala företagare som de lokala politikerna i borgerliga partier gjorde. 
Några ytterligare partiskiljande drag är värda att nämna särskilt. Många centerpartister anmälde täta kontakter med lokala intresseorganisationer (exempelvis byalag). Få miljöpartister rapporterade frekventa kontakter med idrottsföreningar. Jämfört med övriga lokala politiker uppgav ganska många vänsterpartister att de hade upprepade kontakter med invandrarorganisationer. Lokala politiker från vänsterpartiet, socialdemokraterna och centerpartiet tenderade att rapportera frekventa kontakter med kvinnoorganisationer. Detta mönster har också observerats i riksdagen (Wängnerud 1998). Vad gällde de lokala politikerna berodde skillnaderna mellan partierna till en inte ringa del på att vänsterpartistiska, socialdemokratiska och centerpartistiska män oftare än andra män höll kontakt med kvinnoorganisationer. Under 1980-talet fanns även detta mönster i riksdagen, men inte senare under 1990-talet (Wängnerud 1998). Bland kvinnliga lokala politiker var de självrapporterade kontakterna dessutom tätare mellan å ena sidan centerpartister och socialdemokrater och å andra sidan kvinnoorganisationer jämfört med kvinnorna $i$ andra partier.

Ett bra kontaktnät hör ofta samman med inflytande. Också politiska uppdrag i kommunstyrelse och kommunala nämnders presidium samt om politikerna har många uppdrag sätts ofta i samband med inflytande. Dessa lokala politiker har uppnått maktpositioner i enlighet med tidigare resonemang. Låt oss undersöka vilka kontakter som lokala politiker i maktpositioner prioriterade mer än övriga lokala politiker 1999. I tabell 22 redovisas skillnaden i självrapporterad kontaktfrekvens mellan politiker i tre typer av maktpositioner och övriga politiker. Skillnaden presenteras som procentdifferens Först beräknas andelen som ingivit att de haft kontakt med respektive aktör minst några gånger om året. Därefter beräknas skillnaden mellan respektive maktposition och övriga politiker. Det är denna procentdifferens som presenteras i tabell 22.

Överlag uppgav de lokala politikerna i maktpositioner att de var mer aktiva i sina kontakter än andra lokala politiker, ett väntat resultat. Framförallt i kontakterna med lokala företagare, riksdagsledamöter, landstingspolitiker och lokala intresseorganisationer rapporterade innehavarna av maktpositioner att de hade ett mer utvecklat kontaktnät än andra lokala politiker. Mönstret var likartat oavsett typ av maktposition, låt vara att skillnaden mellan politiker som hade två eller fler uppdrag och de som bara hade ett uppdrag tenderade att vara mindre än motsvarande skillnad för politiker i kommunstyrelser och presidier. 
Tabell 22 Skillnaden i kontakfrekvens mellan lokalpolitiker med maktposition (kommunstyrelse, presidium och flera uppdrag) och övriga politiker (procentdifferens).

\begin{tabular}{|c|c|c|c|}
\hline Aktör & $\begin{array}{l}\text { Kommunstyrelse - } \\
\text { övriga politiker }\end{array}$ & $\begin{array}{c}\text { Presidium - övriga } \\
\text { politiker }\end{array}$ & $\begin{array}{l}\text { Politiker med två } \\
\text { eller fler uppdrag - } \\
\text { övriga politiker }\end{array}$ \\
\hline Lokala företagare & +30 & +22 & +11 \\
\hline Riksdagsledamöter & +28 & +26 & +14 \\
\hline Landstingspolitiker & +26 & +24 & +14 \\
\hline Lokal intresseorganisation & +25 & +19 & +13 \\
\hline Ungdomsorganisation & +18 & +12 & +10 \\
\hline Pensionärsorganisation & +18 & +17 & +12 \\
\hline Lokala statliga myndigheter & +18 & +17 & +7 \\
\hline Företagsorganisation & +16 & +15 & +7 \\
\hline Idrottsförening & +14 & +7 & +2 \\
\hline Enskilda väljare & +12 & +13 & -8 \\
\hline Facklig organisation & +11 & +9 & 0 \\
\hline Föräldraförening & +10 & +5 & +5 \\
\hline Kvinnoorganisation & +10 & +7 & +4 \\
\hline Centrala statliga myndigheter & +9 & +15 & +3 \\
\hline Andra svenska företagare & +9 & +9 & 0 \\
\hline Miljöorganisation & +9 & +6 & +4 \\
\hline Regeringstjänstemän & +8 & +11 & +4 \\
\hline Jordbruksorganisation & +8 & +4 & +1 \\
\hline Kulturförening & +7 & +11 & +1 \\
\hline Annat religiöst samfund än Svenska kyrkan & +6 & +1 & +4 \\
\hline Bostadsorganisation & +6 & +10 & +6 \\
\hline Statsråd & +5 & +8 & 0 \\
\hline Arbetsgivarorganisation & +5 & +6 & 0 \\
\hline Konsumentförening/KF & +4 & +4 & 0 \\
\hline EU-myndigheter & +3 & +2 & +1 \\
\hline Svenska kyrkan & +3 & +5 & +5 \\
\hline Invandrarorganisation & 0 & +6 & +3 \\
\hline Utländska företagare & -1 & +1 & -2 \\
\hline
\end{tabular}

Kommentar: Den exakta frågeformuleringen löd som följer. "Den har frågan gäller Dina kontakter som kommunalt förtroendevald med olika organisationer, grupper, föreningar och andra aktörer. Oavsett hur kontakten togs, hur ofta har Du under det senaste året haft skriftliga eller muntliga kontakter med nedanstående aktörer?". Därefter nämndes de 28 aktörerna. För var och en av aktörerna kunde de lokala politikerna uppge att de haft kontakt "Minst en gång i månaden", "Flera gånger det senaste året", "Någon enstaka gång det senaste året" eller "Aldrig". Procentdifferensen beräknas utifrån de som ingivit att de haft kontakt med respektive aktör minst några gånger om året (respektive maktposition minus övriga politiker). 
Vilken betydelse hade de lokala politikernas bakgrund och personliga intressen för kontaktnätet till Organisationssverige? Låt oss granska i vad mån politiker vars bakgrund kunde kopplas till olika kontakter med olika föreningar och organisationer var mer benägna att också rapportera att de upprätthöll sådana kontakter. I tabell 23 redovisas kontaktfrekvensen för politiker med en rad olika egenskaper som sätts i samband med olika samhällsaktörer: föreningsmedlemskap, yrkesgrupp, fritidsaktiviteter med mera.

Om den lokale politikern hade en bakgrund som kunde kopplas till en samhällsaktör, uppges kontakterna ha varit mer intensiva än vad som annars var vanligt. Lokala politiker med medlemskap i föreningar tenderade att rapportera de tätaste kontakterna. Vad gäller självrapporterade kontakter fanns det ibland skillnader mellan olika yrkesgrupper (jordbrukare och till viss del företagare) och åldrar, men oftast var skillnaderna i lokala politikernas självrapporterade kontakter med samhällsaktörer mellan olika yrkesgrupper, fritidsaktiviteter och andra sociala förhållanden inte lika stor som för direkta föreningsmedlemskap. Lokalpolitiker som var medlemmar i Svenska kyrkan och i annat samfund än Svenska kyrkan rapporterade mer intensiva kontakter med respektive organisationer än de lokalpolitiker som besökte religiösa möten regelbundet. Jordbrukare var en yrkesgrupp som rapporterade täta kontakter med jordbruksorganisationer, mycket tätare än de kontakter arbetare och företagare uppgav sig ha haft med fackföreningar respektive företagarnas branschorganisationer. Värt att nämna var också att de som var 66 år och äldre rapporterade nästan lika goda kontakter med pensionärsorganisationer som de som var medlemmar i dessa. Saken berodde till stor del på att de flesta lokala politiker i dessa åldrar också var medlemmar i pensionärsorganisationer.

Enligt de lokala politikernas självrapporterade kontakter med olika samhällsaktörer fanns det ganska många kanaler mellan väljare och valda, åtminstone utifrån den lokala politikerns perspektiv. I vad mån väljarna skulle ha rapporterat samma sak granskades inte i denna undersökning. Vad vår undersökning visade var dock att tillgången till de lokala politikerna varierade. 
Tabell 23 Lokala politikers självrapporterade kontaktfrekvenser med samhällsaktörer 1999, efter föreningsaktivitet, yrkesgrupp, fritidsaktiviteter med mera.

\begin{tabular}{|c|c|}
\hline Facklig organisation & \\
\hline Arbetare & 29 \\
\hline Övriga & 10 \\
\hline Differens & +19 \\
\hline Medlem $i$ fackförening & 41 \\
\hline Inte medlem & 16 \\
\hline Differens & +25 \\
\hline \multicolumn{2}{|l|}{ Jordbruksorganisation } \\
\hline Jordbrukare & 52 \\
\hline Övriga & 5 \\
\hline Differens & +47 \\
\hline \multicolumn{2}{|l|}{ Arbetsgivarorganisation } \\
\hline Företagare & 13 \\
\hline Övriga & 9 \\
\hline Differens & +4 \\
\hline Medlem i företagarorganisation & 18 \\
\hline Inte medlem & 7 \\
\hline Differens & +11 \\
\hline \multicolumn{2}{|l|}{ Företagsorganisation } \\
\hline Företagare & 26 \\
\hline Övriga & 16 \\
\hline Differens & +10 \\
\hline Medlem i företagarorganisation & 38 \\
\hline Inte medlem & 15 \\
\hline Differens & +23 \\
\hline \multicolumn{2}{|l|}{ Lokala företagare } \\
\hline Företagare & 69 \\
\hline Ōvriga & 42 \\
\hline Differens & +27 \\
\hline Medlem i forretagarorganisation & 67 \\
\hline Inte medlem & 39 \\
\hline Differens & +28 \\
\hline \multicolumn{2}{|l|}{ Andra svenska företagare } \\
\hline Företagare & 44 \\
\hline Övriga & 14 \\
\hline Differens & +30 \\
\hline Medlem i företagarorganisation & 34 \\
\hline Inte medlem & 14 \\
\hline Differens & +20 \\
\hline \multicolumn{2}{|l|}{ Utlāndska företagare } \\
\hline Företagare & 19 \\
\hline Övriga & 3 \\
\hline Differens & +16 \\
\hline Medlem i företagarorganisation & 13 \\
\hline Inte medlem & 3 \\
\hline Differens & +10 \\
\hline \multicolumn{2}{|l|}{ Miljöorganisation } \\
\hline Medlem i miljöorganisation & 44 \\
\hline Inte medlem & 13 \\
\hline Differens & +31 \\
\hline \multicolumn{2}{|l|}{ Förăldraförening } \\
\hline Medlem i föräldraförening & 55 \\
\hline Inte medlem & 21 \\
\hline Differens & +34 \\
\hline
\end{tabular}

\begin{tabular}{|c|c|}
\hline \multicolumn{2}{|l|}{ Kvinnoorganisation } \\
\hline Koinnor & 32 \\
\hline Măn & 12 \\
\hline Differens & +20 \\
\hline Medlem $i$ kvinnoorganisation & 69 \\
\hline Inte medlem & 13 \\
\hline Differens & +56 \\
\hline \multicolumn{2}{|l|}{ Ungdomsorganisation } \\
\hline Ung (under 30 dir) & 51 \\
\hline Ovviga & 28 \\
\hline Differens & +23 \\
\hline Medlem $i$ ungdomsorganisation & 66 \\
\hline Inte medlem & 25 \\
\hline Differens & +41 \\
\hline \multicolumn{2}{|l|}{ Pensionärsorganisation } \\
\hline Aldre (66 dr och äldre) & 62 \\
\hline Ōvriga & 24 \\
\hline Differens & +38 \\
\hline Pensionār & 48 \\
\hline Ōvriga & 23 \\
\hline Differens & +25 \\
\hline Medlem $i$ pensionärsorganisation & 66 \\
\hline Inte medlem & 23 \\
\hline Differens & +43 \\
\hline \multicolumn{2}{|l|}{ Idrottsförening } \\
\hline Idrottsutövare & 35 \\
\hline Ōvriga & 28 \\
\hline Differens & +7 \\
\hline Medlem $i$ idrottsförening & 52 \\
\hline Inte medlem & 16 \\
\hline Differens & +36 \\
\hline \multicolumn{2}{|l|}{ Svenska kyrkan } \\
\hline Besōker religiösa möten regelbundet & 53 \\
\hline Ōvriga & 27 \\
\hline Differens & +26 \\
\hline Medlem $i$ organisation $i$ & \\
\hline Svenska kyrkan & 59 \\
\hline Ōvriga & 10 \\
\hline Differens & +49 \\
\hline \multicolumn{2}{|l|}{$\begin{array}{l}\text { Annat religiöst samfund än } \\
\text { Svenska kyrkan }\end{array}$} \\
\hline Besōker religiösa möten regelbundet & 39 \\
\hline Ōvriga & 10 \\
\hline Differens & +29 \\
\hline $\begin{array}{l}\text { Medlem } i \text { annat religiöst samfund } \\
\text { Svenska kyrkan }\end{array}$ & 58 \\
\hline Övriga & 6 \\
\hline Differens & +52 \\
\hline \multicolumn{2}{|l|}{ Invandrarorganisation } \\
\hline Utländsk härkomst & 28 \\
\hline Övriga & 12 \\
\hline Differens & +16 \\
\hline Medlem $i$ invandrarförening & 70 \\
\hline Inte medlem & 11 \\
\hline Differens & +59 \\
\hline
\end{tabular}


Till stor del byggde de lokala politikernas kontaktnät på personliga egenskaper hos politikerna själva. Yrkesgrupp, förening, kön och åldersgrupp som motsvarade politikerns egna egenskaper prioriterades. Det betydde att de grupper som politikerna själva tillhörde hade bättre tillgång till beslutsfattarnas öron än andra grupper. Tilläggas bör att de relativt få lokala politiker som innehade maktpositioner tenderade att ha ett mer omfattande kontaktnät än andra, men det förändrade inte huvudintrycket. Om det var önskvärt att kanalerna mellan väljare och valda skulle ha varit lika tillgängliga för alla grupper i samhället, borde det ha varit önskvärt att alla grupper var lika företrädda bland de lokala politikerna. Så var inte fallet. Kvinnor, unga, äldre, lågutbildade, arbetare och personer med utländsk härkomst hade alltjämt sämre kontakt med lokala politiker i Sverige.

\section{Massmedia - en alternativ kanal?}

Att vara föreningsaktiv är inte det enda sättet för en politiker att hålla kontakt med väljarna. Det är möjligt att argumentera för att föreningsaktivitet främst är knutet till deltagaridealet. Det är enligt deltagaridealet som det är viktigt att ha många kanaler och ett brett deltagande från samhällets många grupper. Sett utifrån det väljarinriktade idealets synvinkel är det centrala att politikerna informerar väljarna om sina åsikter och de beslut som de fattat under den gångna mandatperioden. Inför valet kan sedan väljarna själva bedöma om åsikterna är något som de vill stödja och granska om de fattade besluten var bra. För detta behöver man inte ha personlig kontakt med politikerna. Det viktiga är att få information, till exempel genom tidningar, TV, radio eller internet. I vad mån utnyttjade lokala politiker massmedia som kanal till väljarna i slutet av 1990-talet? Var till exempel publiceringsfrekvens (hur ofta någon skrivit insändare eller debattartikel i en dagstidning) ett alternativ till föreningsaktivitet? I tabell 24 redovisas en jämförelse mellan hur ofta de lokala politikerna var föreningsaktiva utanför partiet och hur ofta de skrev en insändare eller debattartikel i en dagstidning. För att påminna om föreningsaktivitetens närmare koppling till deltagaridealet är den markerad med ett kommunalhus (亚) medan publiceringsfrekvensen markeras med en valurna ( för att påminna om dess koppling till det väljarinriktade idealet. 
Tabell 24 De lokala politikernas självrapporterade föreningsaktivitet och publiceringsfrekvens 1999 (procent).

\begin{tabular}{|c|c|c|c|c|c|c|c|c|c|}
\hline & $\begin{array}{l}\text { Ingen } \\
\text { gång }\end{array}$ & $\begin{array}{c}\text { Någon } \\
\text { gång } \\
\text { under året }\end{array}$ & $\begin{array}{l}\text { Någon } \\
\text { gång } \\
\text { under } \\
\text { halvåret }\end{array}$ & $\begin{array}{c}\text { Någon } \\
\text { gång } i \\
\text { kvartalet }\end{array}$ & $\begin{array}{l}\text { Någon } \\
\text { gång } i \\
\text { månaden }\end{array}$ & $\begin{array}{l}\text { Någon } \\
\text { gång } i \\
\text { veckan }\end{array}$ & $\begin{array}{c}\text { Flera } \\
\text { gånger } i \\
\text { veckan }\end{array}$ & $\begin{array}{l}\text { Summa } \\
\text { procent }\end{array}$ & $\begin{array}{c}\text { Antal } \\
\text { svarande }\end{array}$ \\
\hline \multicolumn{10}{|l|}{ IIIVarit föreningsaktiv } \\
\hline $\begin{array}{l}\text { utanför partiet } \\
\star \text { Skrivit insändarel }\end{array}$ & 19 & 11 & 7 & 12 & 27 & 15 & 9 & 100 & 1760 \\
\hline debattartikel i dagstidning & 43 & 20 & 13 & 15 & 7 & 1 & 1 & 100 & 1752 \\
\hline
\end{tabular}

Kommentar: Frågeformuleringarna löd som följer. "Hur ofta har Du under de senaste 12 månaderna gjort följande saker?" Därefter nämndes bland annat "Varit föreningsaktiv utanför partiet" och "Skrivit insändare/debattartikel i dagstidning". De lokala politikerna kundes svara "Ingen gång", "Någon gång under året", "Någon gång i halvåret", "Någon gång i kvartalet", "Någon gång i månaden", Någon gång i veckan" och "Flera gånger i veckan".

Det var betydligt vanligare att de lokala politikerna var föreningsaktiva utanför partiet än att de skrev debattartiklar och insändare i dagstidningar. Över hälften av de lokala politikerna var föreningsaktiva minst någon gång i månaden, men bara nio procent hade under samma tidsperiod skrivit en insändare eller debattartikel i en dagstidning.

I tabell 25 redovisas föreningsaktiviteten och publiceringsfrekvensen för lokalpolitikerna i respektive parti. För föreningsaktivitet redovisas andelen som uppgivit sig ha varit föreningsaktiv minst en gång i månaden. För publiceringsfrekvens redovisas andelen som skrivit insändare eller debattartikel minst en gång i kvartalet.

Kristdemokraterna och folkpartisterna uppgav sig vara speciellt mycket föreningsaktiva. Miljöpartisterna rapporterade däremot att de inte var särskilt aktiva i föreningar. De uppgav sig däremot tillsammans med vänsterpartisterna att de hade en relativt hög publiceringsfrekvens, medan kristdemokraterna (som var speciellt mycket föreningsaktiva) och moderaterna rapporterade en liten lägre publiceringsfrekvens. 
Tabell 25 De lokala politikernas självrapporterade föreningsaktivitet och publiceringsfrekvens 1999, efter parti (procent).

\begin{tabular}{|c|c|c|c|c|c|c|c|c|c|c|}
\hline & \multicolumn{9}{|c|}{ Parti } & \multirow{2}{*}{$\begin{array}{l}\text { Maximal } \\
\text { skillnad }\end{array}$} \\
\hline & $v$ & $s$ & $m p$ & $c$ & $f p$ & $k d$ & $m$ & övr. & samtliga & \\
\hline $\begin{array}{l}\text { 亚Varit föreningsaktiv } \\
\text { utanför partiet }\end{array}$ & 47 & 52 & 39 & 56 & 60 & 63 & 48 & 39 & 51 & $\pm 24 \mathrm{kd}-\mathrm{mp}$ \\
\hline $\begin{array}{l}\text { Skrivit insändarel } \\
\text { debattartikel i dagstidning }\end{array}$ & 30 & 24 & 30 & 25 & 27 & 21 & 21 & 30 & 24 & $\mathrm{mp}-\mathrm{m}$ \\
\hline
\end{tabular}

Kommentar: Frågeformuleringarna löd som följer. "Hur ofta har Du under de senaste 12 månaderna gjort följande saker?" Därefter nämndes bland annat "Varit föreningsaktiv utanför partiet" och "Skrivit insändare/debattartikel i dagstidning". De lokala politikerna kundes svara "Ingen gång", "Någon gång under året", "Någon gång i halvåret", "Någon gång i kvartalet", "Någon gång i månaden", "Någon gång i veckan" och "Flera gånger i veckan". För föreningsaktivitet anges lokala politiker som uppgivit sig varit föreningsaktiv minst en gång i månaden. För publiceringsfrekvens anges lokala politiker som uppgivit sig skrivit i dagstidning minst en gång i kvartalet.

Föreningsaktivitet (som tidigare redovisats) och publiceringsaktivitet kan variera beroende på olika egenskaper hos de enskilda politikerna. I tabell 26 redovisas föreningsaktiviteten och publiceringsfrekvensen efter social bakgrund och i tabell 27 efter olika politiska egenskaper. Precis som förut redovisas för föreningsaktivitet andelen som uppgivit sig ha varit föreningsaktiv minst en gång $\mathrm{i}$ månaden och för publiceringsfrekvens redovisas andelen som skrivit insändare eller debattartikel minst en gång i kvartalet.

Angående social bakgrund uppvisade ålder två intressanta samband. De som var 67 år och äldre tenderade att uppge sig vara de mest föreningsaktiva, men dessa uppgav också lägst publiceringsfrekvens. Yngre under 30 år rapporterade däremot högst publiceringsfrekvens. Det var således i sin ordning att pensionärer också uppgav hög föreningsaktivitet och låg publiceringsfrekvens (ett förhållande de delar med arbetslösa), medan studerande och ensamstående (som ofta är unga) rapporterade en hög publiceringsfrekvens. Dock bör noteras att frånskilda av någon obekant anledning anmälde en ganska låg publiceringsfrekvens. Vad gäller yrkesgrupper kan sägas att företagare uppgav sig ha lite högre publiceringsfrekvens än andra yrkesgrupper, medan jordbrukarna rapporterade en ganska låg publiceringsfrekvens. Även studerande hade hög publiceringsfrekvens. Regelbundna religiösa mötesbesökare uppgav sig vara mer föreningsaktiva än de som besökte religiösa möten mer sporadiskt eller aldrig. Svaren från de lokala 
politiker som bara varit bosatta i kommunen ett år kanske röjde en del av hemligheten till hur de fått sina uppdrag så snabbt: de uppgav sig vara rekordaktiva. Av de lokala politikerna som bara varit bosatta i kommunen ett år rapporterade sju av tio att de var föreningsaktiva minst en gång i månaden och fyra av tio sa sig skriva insändare eller debattartiklar en gång i kvartalet.

Tabell 26 De lokala politikernas självrapporterade föreningsaktivitet och publiceringsfrekvens 1999, efter social bakgrund (procent).

\begin{tabular}{|c|c|c|}
\hline Kön & $\begin{array}{c}\text { III Varit föreningsaktiv } \\
\text { utanför partiet }\end{array}$ & $\begin{array}{l}\text { Skrivit insändare/- } \\
\text { debattartikel i dagstidning }\end{array}$ \\
\hline Män & 53 & 25 \\
\hline Kvinnor & 49 & 23 \\
\hline \multicolumn{3}{|l|}{ Ålder } \\
\hline 18-29 ar & 51 & 37 \\
\hline $30-44$ år & 50 & 28 \\
\hline $45-54$ & 50 & 23 \\
\hline $55-66 \stackrel{\text { å }}{ }$ & 50 & 23 \\
\hline 67- år & 63 & 13 \\
\hline \multicolumn{3}{|l|}{ Civilstånd } \\
\hline Ensamstående & 56 & 34 \\
\hline Gift/sambo & 50 & 23 \\
\hline Frånskild & 54 & 19 \\
\hline Änka/änkeman & 58 & 24 \\
\hline \multicolumn{3}{|l|}{ Utbildningsnivå } \\
\hline Låg & 52 & 22 \\
\hline Medel & 54 & 22 \\
\hline Hög & 50 & 27 \\
\hline \multicolumn{3}{|l|}{ Typ av anställning } \\
\hline Heltidsanställd & 49 & 22 \\
\hline Deltidsanställd & 44 & 29 \\
\hline Pensionär & 64 & 17 \\
\hline Studerande & 50 & 45 \\
\hline Arbetslös & 59 & 22 \\
\hline Annat & 47 & 32 \\
\hline \multicolumn{3}{|l|}{ Anställningssektor } \\
\hline Privat & 53 & 23 \\
\hline Statlig & 50 & 24 \\
\hline Kommunal/landsting & 49 & 23 \\
\hline
\end{tabular}


Tabell 26 forts.

Yrke

Arbetare $\quad 54 \quad 21$

Tjänsteman, lägre $\quad 50 \quad 23$

Tjänsteman, högre $\quad 54 \quad 24$

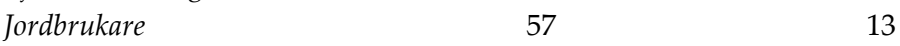

Företagare $\quad 47 \quad 28$

Medborgarskap
Svenskt

Utländskt $\quad 48 \quad 20$

Härkomst

$\begin{array}{lll}\text { Svensk } & 51 & 25\end{array}$

Utländsk $\quad 56 \quad 23$

Religiösa mötesbesök

$\begin{array}{lll}\text { Aldrig } & 43 & 27\end{array}$

Sällan $\quad 49 \quad 23$

Regelbundet $\quad 67 \quad 23$

Bosättningstid i kommunen

1 år och kortare $\quad 69 \quad 38$

2-10 år $\quad 49 \quad 25$

10 år och längre $\quad 51 \quad 24$

Kommentar: Frågeformuleringarna löd som följer. "Hur ofta har Du under de senaste 12 månaderna gjort följande saker?" Därefter nämndes bland annat "Varit föreningsaktiv utanför partiet" och "Skrivit insändare/debattartikel i dagstidning". De lokala politikerna kundes svara "Ingen gång", "Någon gång under året", "Någon gång i halvåret", "Någon gång i kvartalet", "Någon gång i månaden", Någon gång i veckan" och "Flera gånger i veckan". För föreningsaktivitet anges lokala politiker som uppgivit sig varit föreningsaktiv minst en gång i månaden. För publiceringsfrekvens anges lokala politiker som uppgivit sig skrivit i dagstidning minst en gång i kvartalet.

I övrigt var det värt att notera att det inte fanns någon nämnvärd skillnad i självrapporterad föreningsaktivitet och publiceringsfrekvens beroende på kön, utbildningsnivå, anställningssektor, yrkesgrupp, medborgarskap eller utländsk härkomst.

Rörande de politiska egenskaperna fanns de största skillnaderna i publiceringsfrekvens. Ledamöter och suppleanter i kommunfullmäktige och kommunstyrelse samt presidieledamöter och politiker med två uppdrag eller mer rapporterade betydligt högre publiceringsfrekvens än övriga lokala politiker. Dessutom uppgav lokala politiker som befann sig i opposition att de nyttjade pressen mer än majoriteten, något som kunde ingå i rollen som opposition. Slutligen: lokala politiker med ett väljarinriktat ideal tenderade att rapportera 
högre publiceringsfrekvens än de som var orienterade mot deltagaridealet. Däremot fanns inget nämnvärt samband mellan demokratiideal och föreningsaktivitet.

Tabell 27 De lokala politikernas självrapporterade föreningsaktivitet och publiceringsfrekvens, efter demokratiideal och politiska egenskaper (procent).

\begin{tabular}{|c|c|c|}
\hline Kommunfullmäktige & $\begin{array}{c}\text { III Varit föreningsaktiv } \\
\text { utanför partiet }\end{array}$ & $\begin{array}{l}\text { Skrivit insändare/- } \\
\text { debattartikel i dagstidning }\end{array}$ \\
\hline Ledamöter och suppleanter & 47 & 31 \\
\hline Övriga & 57 & 13 \\
\hline \multicolumn{3}{|l|}{ Kommunstyrelse } \\
\hline Ledamöter och suppleanter & 45 & 41 \\
\hline Övriga & 53 & 19 \\
\hline \multicolumn{3}{|l|}{ Högsta position i nämnd } \\
\hline Presidium & 46 & 36 \\
\hline Övriga ledamöter & 50 & 24 \\
\hline Suppleant & 58 & 14 \\
\hline \multicolumn{3}{|l|}{ Antal uppdrag i nämnder } \\
\hline Ett uppdrag & 53 & 21 \\
\hline Två uppdrag & 48 & 30 \\
\hline Tre uppdrag & 48 & 32 \\
\hline Fyra uppdrag eller fler & 45 & 36 \\
\hline \multicolumn{3}{|l|}{ Majoritet eller opposition? } \\
\hline Majoritet & 49 & 21 \\
\hline Opposition & 54 & 28 \\
\hline \multicolumn{3}{|l|}{ Demokratiidealskala } \\
\hline 而 Deltagarinriktad & 51 & 24 \\
\hline Väljarinriktad & 47 & 34 \\
\hline
\end{tabular}

Kommentar: Frågeformuleringarna löd som följer. "Hur ofta har Du under de senaste 12 månaderna gjort följande saker?" Därefter nämndes bland annat "Varit föreningsaktiv utanför partiet" och "Skrivit insändare/debattartikel i dagstidning". De lokala politikerna kundes svara "Ingen gång", "Någon gång under året", "Någon gång i halvåret", "Någon gång i kvartalet", "Någon gång i månaden", Någon gång i veckan" och "Flera gånger i veckan". För föreningsaktivitet anges lokala politiker som uppgivit sig varit föreningsaktiv minst en gång i månaden. För publiceringsfrekvens anges lokala politiker som uppgivit sig ha skrivit i dagstidning minst en gång i kvartalet.

Möjligheten att det väljarinriktade idealet favoriserade bruket av massmedia för att hålla kontakt med väljarna fick alltså empiriskt stöd i så motto att lokala politiker orienterade mot det väljarinriktade idealet rapporterade lite högre publiceringsfrekvens än de som var orienterade mot deltagaridealet. Att bruka 
massmedia tycktes också ha varit ett tillvägagångssätt att kommunicera med väljarna för de lokala politiker som innehade maktpositioner.

\section{Sammanfattning av typer av deltagande}

De lokala politikernas personliga egenskaper hade betydelse för kontakterna mellan väljare och valda. De lokala politikernas kontaktnät var - utifrån deras egna uppgifter - starkt beroende av politikernas sociala bakgrund och fritidsintressen. Ofta hade lokalpolitikerna kontakt med medborgargrupper som liknade politikerna själva eller så var politikerna medlemmar i de föreningar de hade god kontakt med. Det betydde att de grupper som politikern själv tillhörde hade bättre tillgång till beslutsfattarnas öra än andra grupper. För den som likt deltagaridealets anhängare ville ha många och vitt förgrenade kanaler mellan väljare och valda kunde det därför ha betydelse att de lokala politikerna i större utsträckning än befolkningen i övrigt var aktiva i olika föreningar utanför partipolitiken. För den vanliga lokala politikern var det dock inte brukligt att använda massmedia för att kommunicera med väljarna. Istället var massmedia främst en kanal till väljarna för de lokala politiker som satt i olika maktpositioner. Massmedia var också en kanal som prioriteras mer av de lokala politiker som var orienterade mot det väljarinriktade idealet än av deltagaridealets anhängare.

\section{Deltagande i olika sakfrågor}

Deltagande kan ske inom olika politiska sakområden. Med politiskt sakområde menas de ämnen som den politiska aktiviteten avser att påverka. Alla förtroendevalda är knutna till ett politiskt organ: en nämnd, fullmäktige eller kommunstyrelse. Dessa organ har olika beslutandekompetens. De flesta kommunala nämnder har olika verksamhetsområden: de kan handha frågor om infrastruktur och skydd (exempelvis miljö- och byggnämnd), fritid och kultur, skola och förskola (exempelvis utbildningsnämnd), vård och omsorg (exempelvis socialnämnd). Dessutom finns det nämnder som inte är verksamhetsanknutna, till exempel kommunrevisorerna. Till detta kommer kommunstyrelse och 
kommunfullmäktige som inte har något specifikt kompetensområde utan kan sägas ha ett allmänt beslutsområde.

Det var möjligt att deltagandet för olika samhällsgrupper varierade beroende på vilket sakområde som nämnden arbetade med. I det följande undersöks därför vilken social bakgrund de lokala politiker hade som var aktiva inom sina respektive verksamhetsområden 1999. I tabell 28 redovisas flera faktorer om de lokala politikernas sociala bakgrund och andelen lokalpolitiker med sådan bakgrund i respektive verksamhetsområde. Längst ut till höger i tabell 28 redovisas motsvarande andel bland den röstberättigade befolkningen. Genom att jämföra andelen politiker med motsvarande andel bland den röstberättigade delen av befolkningen går det att avgöra $i$ vad mån det föreligger en över- eller underrepresentation av gruppen ifråga.

Enligt tabell 28 var män extra mycket överrepresenterade i kommunala nämnder som handhade frågor om infrastruktur och skydd samt i kommunstyrelsen, vilket betydde att kvinnor var extra mycket underrepresenterade i dessa organ. Kvinnor var överrepresenterade i nämnder inom verksamhetsområdet vård och omsorg, vilket var det enda verksamhetsområde där män var underrepresenterade.

Åldersfördelningen var i huvudsak den samma oavsett verksamhetsområde, med några få undantag. I nämnder som sysslar med skola och förskola var andelen $\mathrm{i}$ yngre medelåldern (mellan 30-44 år) stor, medan andelen politiker som var 67 år och äldre var mycket liten. Inom detta verksamhetsområde var andelen som hade hemmavarande barn stor, vilket många av de lokala politikerna i yngre medelåldern hade (redovisas ej i tabell). De lokala politiker som var verksamma i nämnder som hade hand om fritid och kultur var också jämförelsevis unga. Nästan en tredjedel av de lokala politikerna inom verksamhetsområdet fritid och kultur var under 45 år. Förhållandevis många av de lokala politiker som hade uppdrag inom övriga ej verksamhetsanknutna nämnder var 67 år och äldre. De var främst verksamma som kommunrevisorer. Med tanke på deras ålder var det följdriktigt att nästan var femte lokal politiker inom detta verksamhetsområde var pensionär. Då andelen 67 år och äldre var få inom verksamhetsområdet skola och förskola var det dessutom få pensionärer där. Mindre självklart var det att andelen pensionärer var ungefär lika stor bland de lokala politikerna inom verksamhetsområdet vård och omsorg, medan andelen lokalpolitiker som var 
heltidsanställda och hade politiska uppdrag inom vård och omsorg var mindre än inom andra verksamhetsområden. Gissningsvis finns det bland dessa lokala politiker en och annan deltidsarbetande kvinna inom vårdsektorn.

Tabell 28 Lokala politikerna deltagande i olika verksamhetsområden efter social bakgrund 1999 (procent).

\begin{tabular}{|c|c|c|c|c|c|c|c|c|}
\hline \multirow[b]{2}{*}{ Kön ${ }^{1}$} & \multicolumn{7}{|c|}{ Nämndens verksamhetsområde } & \multirow[b]{2}{*}{ 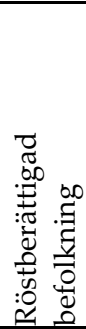 } \\
\hline & 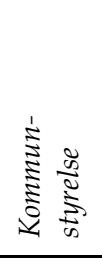 & 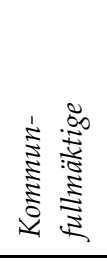 & 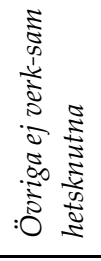 & 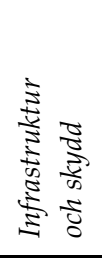 & 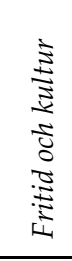 & 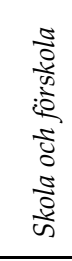 & 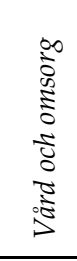 & \\
\hline Män & 61 & 56 & 57 & 69 & 54 & 52 & 39 & 49 \\
\hline Kvinnor & 39 & 44 & 43 & 31 & 46 & 48 & 61 & 51 \\
\hline \multicolumn{9}{|l|}{ Ålder ${ }^{1}$} \\
\hline $18-29$ àr & 4 & 5 & 6 & 6 & 8 & 8 & 6 & 19 \\
\hline $30-44$ år & 20 & 21 & 20 & 20 & 22 & 33 & 17 & 27 \\
\hline $45-54$ & 37 & 33 & 27 & 28 & 34 & 33 & 33 & 18 \\
\hline $55-66 \stackrel{a}{a} r$ & 36 & 35 & 35 & 39 & 29 & 24 & 36 & 16 \\
\hline $67-a ̊ r$ & 3 & 6 & 11 & 7 & 6 & 2 & 8 & 20 \\
\hline \multicolumn{9}{|l|}{ Civilstånd $^{2}$} \\
\hline Ensamstående & 10 & 10 & 13 & 13 & 13 & 11 & 8 & 10 \\
\hline Gift/sambo & 81 & 79 & 76 & 79 & 78 & 82 & 79 & 71 \\
\hline Frånskild & 5 & 8 & 8 & 6 & 6 & 5 & 10 & 11 \\
\hline Änkalänkeman & 3 & 3 & 4 & 2 & 3 & 2 & 3 & 8 \\
\hline \multicolumn{9}{|l|}{ Utbildningsnivå $^{3}$} \\
\hline Låg & 30 & 27 & 28 & 32 & 26 & 27 & 31 & 50 \\
\hline Medel & 24 & 23 & 21 & 24 & 22 & 25 & 25 & 22 \\
\hline Hög & 46 & 51 & 51 & 44 & 52 & 48 & 44 & 28 \\
\hline \multicolumn{9}{|l|}{ Typ av anställning ${ }^{3}$} \\
\hline Heltidsanställd & 56 & 55 & 51 & 52 & 57 & 56 & 48 & 48 \\
\hline Deltidsanställd & 9 & 10 & 8 & 7 & 4 & 13 & 13 & 11 \\
\hline Pensionär & 11 & 14 & 19 & 16 & 14 & 5 & 21 & 23 \\
\hline Studerande & 3 & 4 & 4 & 4 & 6 & 6 & 4 & 9 \\
\hline Arbetslös & 2 & 3 & 4 & 5 & 6 & 5 & 2 & 5 \\
\hline Annat & 18 & 15 & 13 & 15 & 12 & 14 & 12 & 4 \\
\hline \multicolumn{9}{|l|}{ Anställningssektor ${ }^{3}$} \\
\hline Privat & 44 & 46 & 51 & 51 & 44 & 41 & 36 & 58 \\
\hline Statlig & 18 & 15 & 14 & 18 & 14 & 15 & 17 & 12 \\
\hline Kommunal/landsting & 38 & 39 & 36 & 32 & 42 & 44 & 47 & 30 \\
\hline
\end{tabular}


Tabell 28 forts.

Yrke $^{3}$

Arbetare

Tjänsteman, lägre

Tjänsteman, högre

Jordbrukare

Företagare

Medborgarskap ${ }^{4}$

Svenskt

Utländskt

Härkomst ${ }^{5}$

Svensk

Utländsk

Religiösa mötesbesö $\mathbf{k}^{3}$

Aldrig

Sällan

Regelbundet

$\begin{array}{cccccccc}20 & 20 & 18 & 24 & 23 & 26 & 25 & 47 \\ 34 & 34 & 34 & 32 & 38 & 34 & 39 & 29 \\ 29 & 29 & 35 & 25 & 22 & 24 & 25 & 15 \\ 6 & 4 & 3 & 6 & 4 & 3 & 3 & 1 \\ 11 & 13 & 11 & 14 & 12 & 13 & 9 & 8 \\ & & & & & & & \\ 99 & 99 & 98 & 98 & 98 & 99 & 99 & 95 \\ 1 & 1 & 2 & 2 & 2 & 1 & 1 & 5 \\ & & & & & & & \\ 94 & 89 & 84 & 89 & 87 & 92 & 88 & 81 \\ 6 & 11 & 16 & 11 & 13 & 8 & 12 & 19 \\ & & & & & & & \\ 36 & 35 & 38 & 37 & 35 & 38 & 32 & 53 \\ 46 & 44 & 37 & 45 & 42 & 43 & 43 & 37 \\ 19 & 21 & 26 & 18 & 23 & 19 & 25 & 10 \\ & & & & & & & \\ 2 & 1 & 1 & 1 & 1 & 1 & 0 & 4 \\ 14 & 15 & 14 & 14 & 17 & 21 & 17 & 20 \\ 84 & 85 & 86 & 85 & 82 & 78 & 83 & 76\end{array}$

Kommentar: Procentdifferensen beräknas genom att subtrahera procentandelen lokala politiker från procentandelen röstberättigad befolkning. Källor för uppgifter om röstberättigad befolkning: ${ }^{1} \mathrm{SCB}$ 1999a, s 57-58. ${ }^{2}$ Uppgifterna är hämtade dels från SCB 1999a, s 56 och SOM-undersökningen 1998 (Lithner 1999). ${ }^{3}$ SOM-undersökningen 1998 (Lithner 1999). ${ }^{4}$ SCB 1999a, s 80. ${ }^{5}$ SCB 1999b, s 60-65.

Inom verksamhetsområdena infrastruktur och skydd samt övriga ej verksamhetsanknutna nämnder var varannan lokal politiker privatanställd, vilket var lite mer än inom andra verksamhetsområden. Däremot var endast drygt en tredjedel av de lokala politikerna inom vård och omsorg privatanställda. Där fanns istället extra många kommun- och landstingsanställda. Arbetarna var överlag underrepresenterade, men vad gällde övriga ej verksamhetsanknutna nämnder var andelen arbetare extra liten. Istället var de högre tjänstemännen - som överlag var överrepresenterade - extra överrepresenterade inom detta verksamhetsområde. Tidigare nämndes att jordbrukarna var starkt överrepresenterade bland de lokala politikerna. Till detta kan läggas att jordbrukarna lyckades samla en stor del av sina styrkor i kommunstyrelserna. Bland de lokala politikerna som arbetade med frågor rörande infrastruktur och skydd var också jämförelsevis många jordbrukare. 
Personer med utländsk härkomst var inte bara få, de var även ojämnt fördelade mellan de olika verksamhetsområdena. I kommunstyrelserna hade bara var tjugonde lokal politiker utländsk härkomst (det vill säga första eller andra generationen med utländsk bakgrund) och inom verksamhetsområdet skola och förskola hade endast var tolfte lokal politiker utländsk härkomst. Däremot fanns relativt många med utländsk härkomst inom verksamhetsområdet övriga ej verksamhetsanknutna nämnder. Där fanns också ganska många regelbundna religiösa mötesbesökare. Dessa återfinns även i stor utsträckning inom verksamhetsområdet vård och omsorg.

Sammanfattningsvis kan konstateras att olika samhällsgruppers deltagande i den representativa demokratin skiftade beroende på vilka sakfrågor som behandlas. Det bör observeras att i kommunstyrelsen var kvinnor och personer med utländsk härkomst extra underrepresenterade. Kvinnor var också extra underrepresenterade inom verksamhetsområdet infrastruktur och skydd. Däremot var kvinnor tillsammans med pensionärer, kommun- och landstingsanställda samt regelbundna religiösa mötesbesökare överrepresenterade inom verksamhetsområdet vård och omsorg. Inom verksamhetsområdet skola och förskola var "föräldragenerationen" - personer i mellan 30-44 år som ofta hade hemmavarande barn överrepresenterade, medan äldre, pensionärer samt personer med utländsk härkomst var extra underrepresenterade.

\section{Deltagandets kvalitet}

De lokala politikernas deltagande $\mathrm{i}$ den representativa demokratin kan ha olika kvalitet. Att bestämma vad som menas med kvalitet är svårt då begreppet med nödvändighet är subjektivt, mångskiftande och vagt. I denna studie rör deltagandets kvalitet följande faktorer: individens uppfattning av deltagandets nytta, måluppfyllelse, inflytande, tillfredsställelse samt grad av aktivitet under och omsorg om deltagandet. Deltagandets kvalitet berör således inte bara närvaro eller innehav av uppdrag, utan också på vilket sätt den lokala politikern förvaltar sitt uppdrag. Begreppets karaktär gör det nödvändigt att använda flera indikatorer på 
kvalitet. Deltagande kan ske med olika grader av aktivitet och omsorg. Hur vanligt är det att de lokala politikerna yttrar sig under nämndsammanträdena? Vilken tid lägger de ned på sina kommunalpolitiska åtaganden? Ovan nämndes att deltagandets sakområde är av betydelse. Att få arbeta med intressanta sakområden är en indikator på måluppfyllelse och tillfredsställelse. Sitter de lokala politikerna i den nämnd de helst vill vara ledamöter i? Även förmåga till inflytande är betydelsefullt för att tillfredsställa en politiker. Upplever de lokala politikerna att de har inflytande? Är det politiska deltagandet så tillfredsställande att de lokala politikerna har ambitionen att fortsätta i framtiden, eller planera de att avveckla sin politiska karriär?

I tabell 29 finns en sammanställning över uppgifter som har för avsikt att besvara samtliga av dessa frågor vad gäller 1999 års lokala politiker. I tredje kolumnen från höger redovisas uppgifterna för samtliga svarande, men i tabell 29 finns även uppgifter för respektive parti. Låt oss gå igenom de olika indikatorerna på kvalitativt deltagande en i sänder.

Tabell 29 Lokala politikers kvalitativa deltagande 1999 efter parti och samtliga (procent respektive medelvärde).

\begin{tabular}{|c|c|c|c|c|c|c|c|c|c|c|c|}
\hline \multirow[b]{2}{*}{ Kvalitativt deltagande } & \multicolumn{8}{|c|}{ Parti } & \multirow[b]{2}{*}{ samtliga } & \multirow{2}{*}{\multicolumn{2}{|c|}{ Maximal skillnad }} \\
\hline & $\mathrm{v}$ & $\mathrm{s}$ & $\mathrm{mp}$ & c & fp & $\mathrm{kd}$ & $\mathrm{m}$ & övr. & & & \\
\hline $\begin{array}{l}\text { Antal air kommunalpolitisk } \\
\text { erfarenhet }\end{array}$ & 9,6 & 14,6 & 8,0 & 14,7 & 16,3 & 7,8 & 13,1 & 11,0 & 12,9 & $\pm 8,5$ & fp-kd \\
\hline $\begin{array}{l}\text { Antal timmar } i \text { veckan för } \\
\text { kommunalpolitiska åtaganden } \\
\text { Antal timmar } i \text { veckan för } \\
\text { kommunalpolitiska åtaganden }\end{array}$ & 10,0 & 10,3 & 9,0 & 9,9 & 8,2 & 8,6 & 10,6 & 9,4 & 9,9 & $\pm 2,4$ & m-fp \\
\hline per nämnduppdrag & 7,1 & 8,0 & 7,1 & 7,9 & 7,1 & 5,9 & 7,1 & 7,3 & 7,4 & $\pm 2,1$ & s-kd \\
\hline Förverkligad nämndpreferens & 59 & 67 & 67 & 68 & 62 & 73 & 66 & 60 & 65 & \pm 14 & $\mathrm{kd}-\mathrm{v}$ \\
\hline $\begin{array}{l}\text { Yttrar sig nästan alltid under } \\
\text { lokala partimöten }\end{array}$ & 79 & 55 & 75 & 66 & 74 & 71 & 62 & 80 & 64 & \pm 24 & $\mathrm{~V}-\mathrm{S}$ \\
\hline $\begin{array}{l}\text { Yttrar sig nästan alltid under } \\
\text { nämndsammanträden }\end{array}$ & 61 & 52 & 62 & 56 & 58 & 48 & 61 & 60 & 56 & \pm 14 & $\mathrm{mp}-\mathrm{kd}$ \\
\hline
\end{tabular}


Magnus Hagevi

Tabell 29 forts.

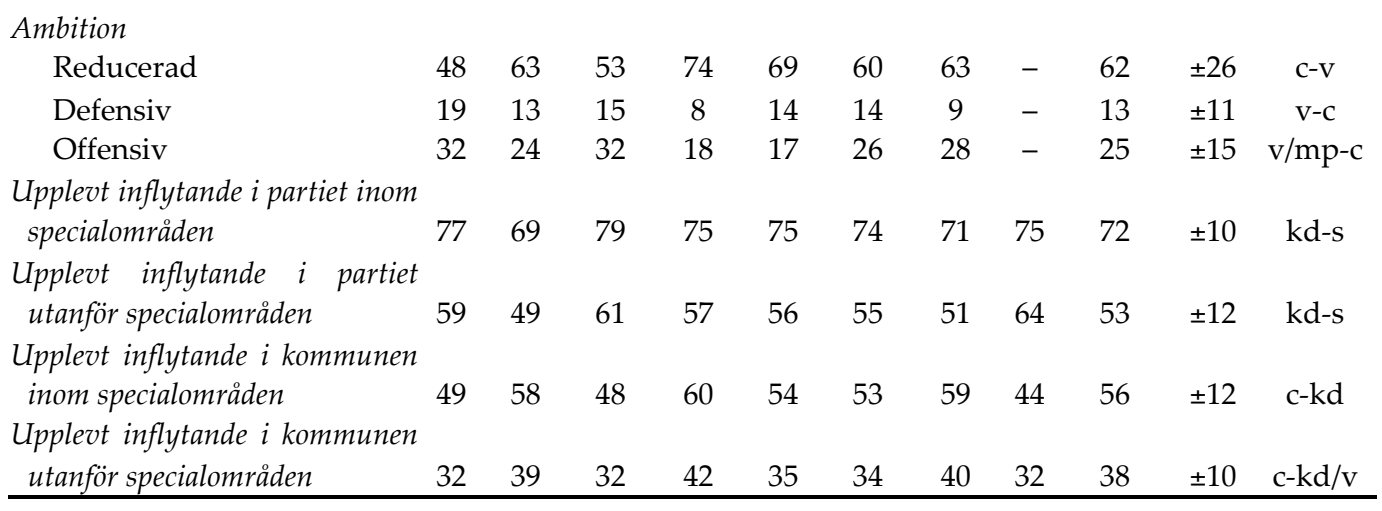

Kommentar: Förverkligad nämndpreferens är de lokala politiker som sitter i den nämnd de helst vill vara ledamot av (så kallad nämndpreferens). Nämndpreferensen undersöktes med följande fråga: "Om Du fick välja fritt, vilken kommunal nämnd skulle Du då helst vara ordinarie ledamot av?" Svaren har jämförts med de lokala politikernas nuvarande faktiska uppdrag. Yttrandefrekvens mäts med följande fråga: "Ungefär hur ofta yttrar Du Dig under a) lokala partimöten? b) sammanträden i Din kommunala nämnd?" Svarsalternativen var "Nästan alltid", "Oftast", "Då och då", "Sällan" och "Aldrig". Ambition mäts med hjälp av följande fråga: "Vad skulle Du helst vilja ha för uppdrag om ungefär tio år?" Därefter nämndes en rad uppdrag på kommunal, landstings-, statlig och EU nivå. Svaren har jämförts med de lokala politikernas nuvarande faktiska uppdrag. De som vill ha fler uppdrag och på högre nivåer än nu betecknas ha en offensiv ambition. De som endast uppger sig vilja behålla sina nuvarande uppdrag betecknas ha en defensiv ambition. De som vill avveckla sina uppdrag betecknas ha en reducerad ambition. Antal timmar i veckan för kommunalpolitiska åtaganden mättes med följande fråga: "Uppskattningsvis, hur många timmar använder Du för att sköta Dina kommunalpolitiska åtaganden en genomsnittlig vecka?" Genom att dividera svaret på denna fråga med svarspersonens antal kommunalpolitisk uppdrag erhålles antal timmar i veckan för kommunalpolitiska åtaganden per nämnduppdrag. Upplevt inflytande uppmättes med följande fråga: "Vilken är Din bedömning av Dina möjligheter att påverka besluten i olika kommunala frågor?" Svarspersonerna uppmanades att svara med hjälp av en 11-gradig skala från 0 (mycket litet inflytande) till 10 (mycket stort inflytande). Svarspersonerna kunde ange sin bedömning på fyra områden: "I Ditt parti inom Dina specialområden", "I Ditt parti utanför Dina specialområden", "I Din kommun inom Dina specialområden" samt "I Din kommun utanför Dina specialområden". Svaren har multiplicerats med 10 .

Det finns argument för att både lång och kort erfarenhet av politik av politik gagnar ett politiskt värv. Lång erfarenhet anses ibland indikera tillfredsställelse med uppdraget, att det är åtråvärt och att man inte vill avsluta det. Men lång erfarenhet kan också visa på en stängd miljö där nykomlingar har det svårt att ta sig in och göra sig gällande, eller på svårigheter att rekrytera färskt blod. Det politiska deltagandet begränsar sig då till en grupp med liten omsättning. Det är komplicerat att applicera deltagaridealet till politisk erfarenhet, då "lagom" 
erfarenhet är att rekommendera enligt detta ideal. Det politiska deltagandet ska vara så tillfredsställande att de individuella deltagarna inte hoppar av, men samtidigt ska omsättningen vara så hög att alla medborgare någon gång under sin levnad har möjlighet att inneha ett offentligt politiskt uppdrag. Rent matematiskt går det att beräkna att om ungefär hälften av de valbara invånarna i Sverige ska ha möjlighet att inneha ett av de 68500 kommunalpolitiska uppdragen under sin levnad, så bör den genomsnittliga erfarenheten av kommunalpolitik vara 6 år. Låt detta vara ett numeriskt riktmärke för deltagaridealet. För anhängarna av det väljarinriktade idealet finns dock inte något sådant riktmärke. De kan istället resonera så här: "Förvisso kan det vara bra att många har varit förtroendevalda, men det viktigaste är att vi har duktiga politiker och då kan det inte skada med politisk erfarenhet."

Hur var det då med de lokala politikernas kommunalpolitiska erfarenhet 1999 ? Enligt tabell 29 hade de flesta lokala politiker en omfattande kommunalpolitisk erfarenhet, i genomsnitt nästan 13 år. Verklighetens lokala politiker hade således oftast en mycket större politisk erfarenhet än vad anhängarna av deltagaridealet skulle ha önskat. Däremot skulle de som var orienterade mot det väljarinriktade idealet inte ha några invändningar. Närmast deltagaridealet låg kristdemokraterna och miljöpartisterna - två partier som vars väljarstöd hade ökat mycket under 1990-talet. Folkpartisterna var däremot längst bort från deltagaridealet med en genomsnittlig kommunalpolitisk erfarenhet på över 16 år.

Deltagaridealts anhängare menar att politikerna inte ska samla på sig många uppdrag, utan fördela dem sig emellan så att så många som möjligt kan inneha ett politiskt uppdrag. Då anses dessutom politikerna kunna lägga ned mer tid på sitt uppdrag och därigenom sköta det bättre. De som är orienterade mot det väljarinriktade idealet menar dock att makten ska vara tydlig, så det gör ingenting att några politiker har många uppdrag.

Den genomsnittliga lokalpolitikern lade ned ungefär 10 timmar på sina kommunalpolitiska åtaganden. Variationerna mellan partierna var inte så stora (moderaternas 10,6 timmar jämfört med folkpartisternas 8,2 timmar). ${ }^{10}$ Det genomsnittliga antalet timmar per uppdrag var lägre, ungefär 7 och en halv timme per uppdrag. Också nu var skillnaderna mellan partierna små (socialdemokraternas 8,0 timmar jämfört med kristdemokraternas 5,9 timmar). 
Ytterligare en indikator på deltagandets kvalitet är om de lokala politikerna uppnår sina mål. Som tidigare nämnts kan de lokala politikerna vara ledamöter eller suppleanter i kommunala nämnder som handhar olika verksamhetsområden. Men det är inte säkert att de kan sitta i den nämnd som de allra helst vill vara ledamöter i. Somliga nämnder är populärare än andra. Samtidigt är antalet platser i nämnderna begränsat. Därför kan inte alla få plats i sin favoritnämnd. I enkätundersökningen ställdes frågor om vilken nämnd de lokala politikerna helst ville vara ledamöter av, så kallad nämndpreferens. Denna har sedan jämförts med deras faktiska nämnduppdrag. De som då innehar ett uppdrag som överensstämmer med deras nämndpreferens har en förverkligad nämndpreferens. Att inneha en förverkligad nämndpreferens bör indikera ett visst mått av måluppfyllelse, vilket bör leda till en större grad av tillfredsställelse för den enskilda politikern.

Enligt tabell 29 hade nästan två tredjedelar av de lokala politikerna förverkligat sin nämndpreferens. Det betydde att de flesta lokala politiker tenderade att arbeta $\mathrm{i}$ den nämnd de helst ville sitta i och med de frågor de helst ville arbeta med. Några större skillnader mellan partierna fanns inte.

En annan indikator på deltagandets kvalitet är den lokala politikerns aktivitet. Till exempel är den politiker som ofta gör sin stämma hörd mer aktiv än en politiker som aldrig höjer sin stämma för att påverka, kommentera eller kritisera. Inom kommunalpolitiken finns det olika arenor som det är möjligt att vara aktiv på. I denna studie beaktas två arenor: lokala partimöten och nämndsammanträden. Dessa arenor skiljer sig åt på ett par områden. Partimöten fungerar ofta som en informationscentral för vad som händer på andra håll i partiet. Under partimötena har medlemmarna större möjlighet att påverka helheten av partipolitikens utformning och kan verka över ett bredare antal frågor än vad det vanliga nämnduppdraget annars ger möjlighet till. Under partimötena utformas ofta huvudlinjerna i partiernas politik, partiernas förslag till kommunala beslut. I samband med nämndsammanträdena konfronteras sedan partiernas politik med representanter från andra partier för att sedan fatta det kommunala beslutet. $\mathrm{Nu}$ gäller frågan: Hur ofta yttrade sig de lokala politikerna på dessa arenor 1999? I tabell 29 redovisas hur många av de lokala politikerna som nästan alltid yttrade sig under lokala partimöten eller nämndsammanträden.

$842015: 2 \mathrm{nr} 1-2 \mid$ SurveyJournalen 
Det var något mer vanligt att lokala politiker yttrade sig under lokala partimöten än under nämndsammanträden. Beträffande nämndsammanträdena fanns inte någon större skillnad mellan partierna. Däremot fanns det en tendens att lokala politiker från numerärt stora partier (som socialdemokraterna och moderaterna) yttrade sig något mindre frekvent under partimötena än lokala politiker från mindre partier. Den främsta anledningen till detta torde ha varit att stora och små partier hade ungefär samma tid till förfogande till sammanträden, men i stora partier var det fler som ville dela på den tiden än i små partier. Därför var det svårt (och kanske dessutom kontraproduktivt) att yttra sig lika ofta i stora partier som i små. I nämnderna var däremot partierna mer "på jämställd fot" - möjligheterna att yttra sig var inte längre lika beroende av partiernas respektive storlek.

För att undersöka vilka ambitioner de lokala politikerna hade med sin politiska karriär tillfrågades de om vad de helst ville ha för uppdrag om ungefär tio år. Detta jämfördes med deras uppdragsinnehav 1999. I tabell 29 redovisas resultatet. Nästan två tredjedelar av de lokala politikerna hade en reducerad ambition, det vill säga de ville dra ned på eller helt avveckla sitt politiska engagemang. Var fjärde lokal politiker hade däremot en offensiv ambition och ville satsa på en politisk karriär. Övriga lokala politiker var nöjda med vad de hade och ville behålla sina uppdrag, vilket betecknas som en defensiv ambition. Resultatet pekade på ett stort framtida rekryteringsbehov till politikerkåren i landets kommuner. En del partier tycktes ha ett större behov av att rekrytera nya politiker än andra. Tre fjärdedelar av centerpartisterna planerade att dra ned på eller avveckla sin politiska karriär. Situationen var inte lika akut i alla partier. Av vänsterpartisterna och miljöpartisterna planerade ungefär hälften sin politiska reträtt.

Det är att anta att förmågan till inflytande är viktigt för att tillfredsställa en politiker. Därför behandlar nästa fråga om de lokala politikerna upplever sig ha inflytande. Återigen kan förhållandena skifta mellan de båda arenorna parti och kommun, men även vilka sakfrågor som behandlas är viktigt. Det är ett välkänt faktum att politiker ofta tenderar att specialisera sig och få inflytande inom ett verksamhetsområde - även kallat specialområde - medan inflytandet oftast är mindre i frågor som ligger utanför specialområdet. Detta innebär att de lokala politikernas upplevda inflytande bör analyseras utifrån fyra aspekter: i partiet 
inom specialområdena, i partiet utanför specialområdena, i kommunen inom specialområdena och i kommunen utanför specialområdena.

För att undersöka de lokala politikernas uppfattning om sitt eget inflytande fick de bedöma sina möjligheter att påverka besluten i kommunala frågor genom en 11gradig skala från 0 (mycket litet inflytande) till 10 (mycket stort inflytande). De lokala politikerna använde skalan för att markera sitt inflytande i sitt parti inom sina specialområden, i sitt parti utanför sina specialområden, i sin kommun inom sina specialområden samt i sin kommun utanför sina specialområden. För att undvika decimaler i redovisningen har de lokala politikernas svar multiplicerats med 10. Därefter beräknades medelvärdet (M) av de lokala politikernas svar.

För de lokala politikerna var specialisering viktigt. Det var inom de egna specialområdena som de upplevde sig ha störst inflytande, både i parti och i kommun. Otvetydigt störst inflytande upplevde de lokala politikerna att de hade i partiet inom de egna specialområdena $(M=72)$. Därnäst kom inflytande $i$ kommunen inom de egna specialområdena $(M=56)$, strax följt av partiet utanför de egna specialområdena $(\mathrm{M}=53)$. Jämförelsevis lite inflytande upplevde de lokala politikerna att de hade i kommunen utanför det egna specialområdet $(\mathrm{M}=38)$. De lokala politikerna ansåg således att det egna inflytandet skiftade mycket beroende på arena och sakfråga.

På partinivå noterades att politiker som upplevde sig ha jämförelsevis stort inflytande inom partiet tenderade att tycka att de hade relativt lite inflytande $\mathrm{i}$ kommunen. Låt oss ta miljöpartisterna som exempel. Jämfört med övriga partier upplevde miljöpartisterna stort inflytande inom sina partier. Men i kommunen upplevde miljöpartisterna sig ha litet inflytande. För socialdemokraterna och moderaterna var det i stort sett tvärtom: de upplevde sig ha relativt lite inflytande i det egna partiet, men jämfört med andra partier upplevde de sig ha ganska stort inflytande i kommunen. Återigen var troligtvis partiernas storlek en viktig faktor. I stora partier tvingades de lokala politikerna att dela med sig av inflytande till många partikamrater. Därför upplevde de sig ha mindre inflytande än i små partier där det ofta inte fanns lika många partikamrater att dela makten med. När fokus förflyttades från den partiinterna arenan till den kommunala, fann de lokala politikerna att partistorleken var en fördel om de ville ha inflytande. Lokala 
politiker från stora partier fann att de oftare kunde bestämma mer i kommunerna än lokala politiker som representerade små partier.

De lokala politikernas deltagande kännetecknades således av långa politiska karriärer och låg omsättning. De som hade etablerat sig i den lokala representativa demokratin hade hög grad av måluppfyllelse i den meningen att de arbetade med de frågor de var intresserade av. I stora partier var det tvunget att de lokala politikerna i relativ stor omfattning delade med sig av inflytande till många partivänner. De upplevde sig därför ha relativt litet inflytande inom det egna partiet i jämförelse med vad kollegorna i små partier upplevde sig ha. Beträffande upplevelser av inflytande i kommunen gav tillhörighet till ett stort parti motsatt effekt. Lokala politiker i stora partier upplevde sig ha större inflytande än kollegorna i små partier. Antagligen berodde detta på att stora partier tenderade att ha större inflytande i kommunerna än små partier.

\section{Skillnader mellan lokala politikers kvalitativa deltagande}

I flera av de analyser som presenterades tidigare i denna rapport konstaterades att vissa grupper ofta tenderade att ta för sig mer än andra $\mathrm{i}$ den kommunala politiken. Högutbildade män i övre medelåldern med tjänstemannayrken inom den offentliga sektorn, härstammande från Sverige och gärna religiöst aktiva var de egenskaper som ofta var överrepresenterade bland de lokala politikerna. Detta gällde nästan oavsett typ av deltagande eller vilka sakfrågor deltagandet gällde. Men det var en sak att vara överrepresenterad numerärt, en annan sak vad varje individ fick ut av sitt uppdrag kvalitativt. Var det så att högutbildade män i övre medelåldern med tjänstemannayrken inom den offentliga sektorn, härstammande från Sverige och gärna religiöst aktiva var de som hade den högsta kvalitet på sitt deltagande i den lokala representativa demokratin? I så fall var dessa grupper inte bara överrepresenterade numerärt utan även kvalitativt, en slags dubbel överrepresentation. Eller var det så att några av de annars underrepresenterade grupperna kunde "ta igen" lite av sin numerära underrepresentation genom ett högre kvalitativt deltagande? I tabell 30 presenteras samtliga indikatorer på deltagandets kvalitet efter de lokala politikernas sociala bakgrund. 


\section{Magnus Hagevi}

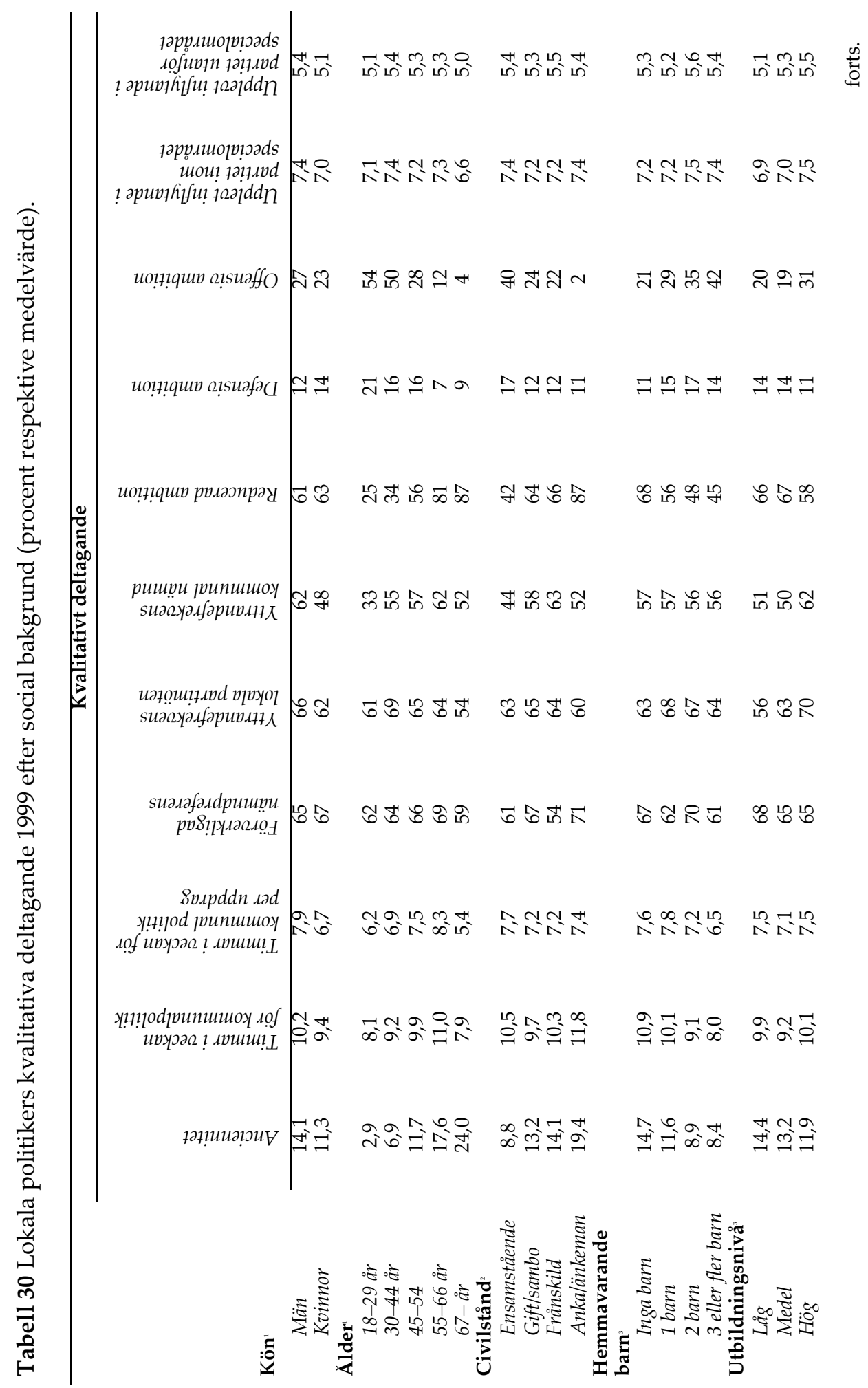




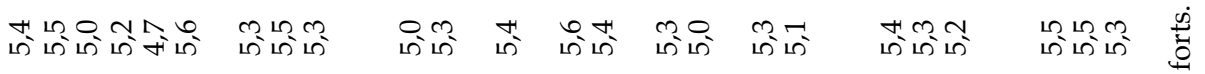

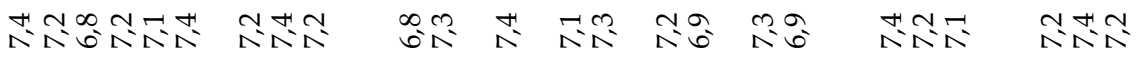

तิ

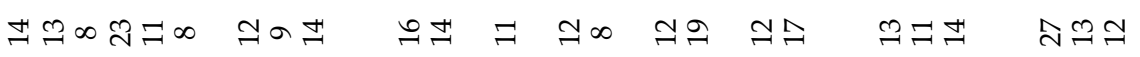

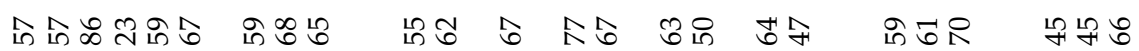

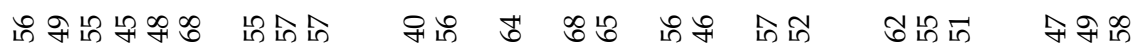

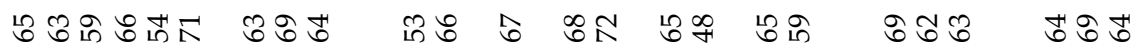

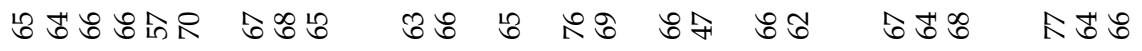

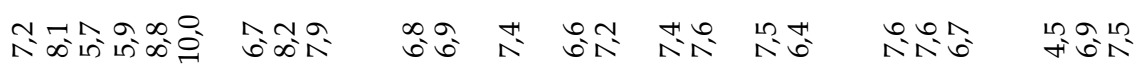

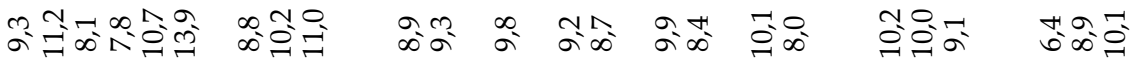

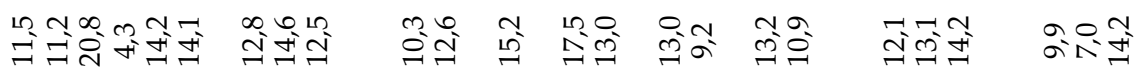

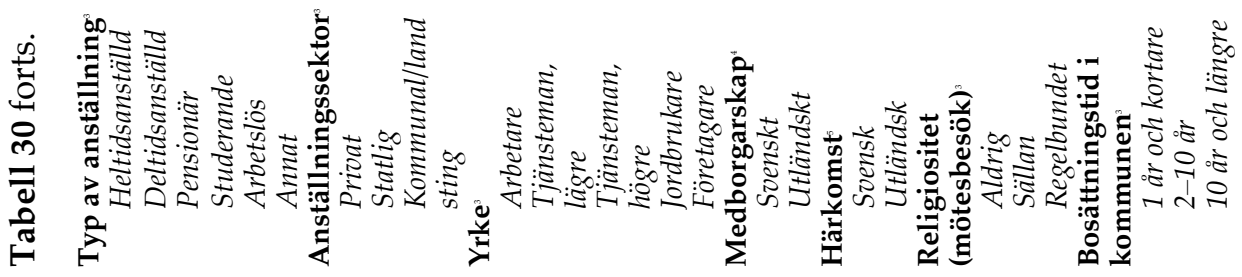




\section{Magnus Hagevi}

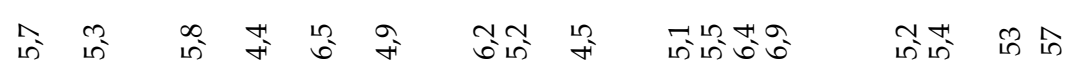

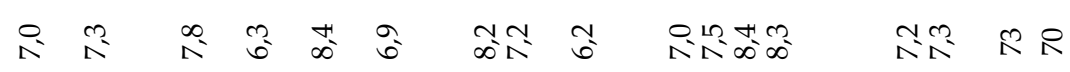

க) तิ तี ल

$\therefore$ ㄴำ

ช ชู

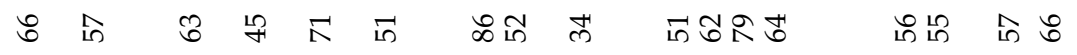

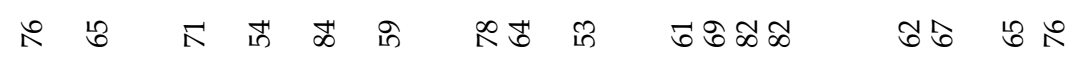

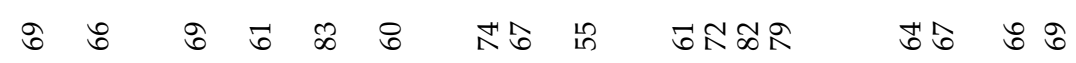

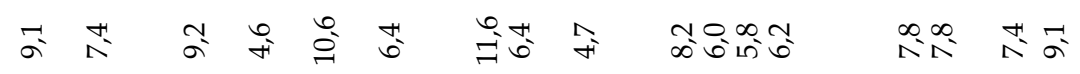

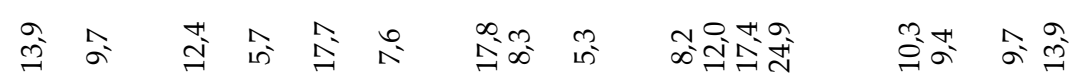

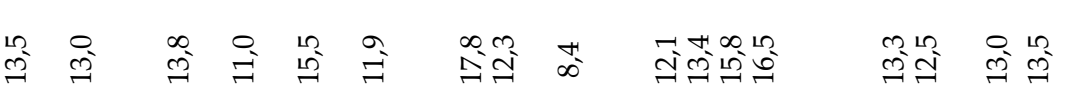

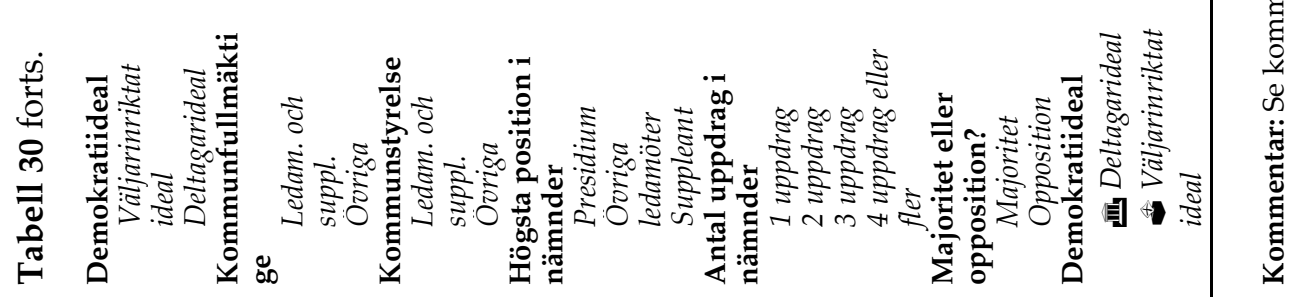

$90 \quad 2015: 2 \mathrm{nr} 1-2 \mid$ SurveyJournalen 
Det var knappast några underrepresenterade grupper som tog igen sin numerära underrepresentation genom ett högre kvalitativt deltagande, snarare var det så att de överrepresenterade grupperna drog ifrån och ökade avståndet. Men en faktor signalerade en framtida förändring: några av de underrepresenterade grupperna hade en förhållandevis stark offensiv ambition, de ville göra mer av sin politiska karriär. Låt oss gå igenom de olika sociala bakgrundsfaktorerna med avseende på kvalitativt deltagande.

Nästan varje indikator på deltagandets kvalitet visade högre värden för män än för kvinnor. Enda undantaget var att kvinnor uppvisade en icke statistisk signifikant andel fler förverkligade nämndpreferenser än män. Inom vissa verksamhetsområdena var män extra mycket överrepresenterade (exempelvis infrastruktur och skydd, kommunstyrelse) medan kvinnor var överrepresenterade inom vård och omsorg. Det var möjligt att detta kunde bero på att kvinnor hade det lättare att förverkliga sina nämndpreferenser inom "kvinnliga" verksamhetsområden och svårare inom "manliga" och vice versa för män (se Skeije 1992; Wängnerud 1998). Så var dock inte fallet. Kvinnor och män förverkligade oberoende av verksamhetsområde sina nämndpreferenser i ungefär lika stor omfattning (redovisas ej i tabell). I övrigt hade män längre kommunalpolitisk erfarenhet än kvinnor. Män rapporterade att de lade ned fler timmar i veckan på kommunalpolitiska åtaganden än kvinnor, både per uppdrag och sammanlagt. Män uppgav att de yttrade sig betydligt oftare i de kommunala nämnderna än kvinnor. Män uppfattade överlag sig ha större inflytande än kvinnor i det egna partiet och i kommunen. Även om det skulle vara möjligt att, något spekulativt, anta att män överdrev sitt kvalitativa deltagande i större utsträckning än kvinnor, så visade resultaten att män subjektivt upplever sig ha större kvalitativt deltagande än kvinnor.

Ålder påverkade de lokala politikernas kvalitativa deltagande. Unga lokala politiker under 30 år uppgav att de yttrade sig sällan i sin kommunala nämnd, men däremot att de tog till orda under lokala partimöten. Det var således inte att förvåna att unga uppfattade att de hade lite mer inflytande inom det egna partiet än inom kommunen, både inom och utanför sina specialområden. De flesta unga hade en offensiv ambition: de ville fortsätta att göra en politisk karriär. Samtidigt uppgav var fjärde ung politiker att de ville dra ned på sitt politiska engagemang. De värden som indikerar högst kvalitet på deltagandet var annars att finna bland 
de lokala politikerna i övre medelåldern. Fram till pensionsålder lade de lokala politikerna ned mer och mer tid på sina kommunalpolitiska åtaganden. Men efter den 67:e födelsedagen minskade antalet timmar som gick åt till kommunalpolitiska åtaganden. Överlag visade de kvalitativa indikatorerna på kvalitet på en reträtt för äldre lokala politiker. De upplevde sig ha relativt lite inflytande, deras nämndpreferens var förverkligad i allt mindre utsträckning, de yttrade sig ganska sällan och planerade att avsluta sin politiska karriär.

Enligt undersökningsresultatet uppgav frånskilda lokala politiker att de oftare än andra yttrade sig under sammanträdena i deras kommunala nämnd. I övrigt uppvisade civilstånd inga samband som inte kunde förklaras med ålder eller kommunalpolitisk erfarenhet.

Man skulle kunna tro att högutbildade skulle ha högre kvalitativt deltagande än lågutbildade. Men så var inte alltid fallet. De lokala politikerna förverkligade sin utskottspreferens i ungefär lika stor utsträckning oavsett utbildningsnivå. Lågutbildade ansåg att de hade minst lika stort inflytande i kommunen som högutbildade. Lågutbildade tenderade att ha längre politisk erfarenhet än högutbildade och lågutbildade lade ned ungefär lika mycket tid på sina uppdrag som högutbildade. Mot bakgrund av att högutbildade var kraftigt överrepresenterade bland lokala politiker och att de i större utsträckning än lågutbildade tenderade att ha uppdrag som kunde karaktäriseras som maktpositioner betydde det att den politiska karriären gått snabbare för de högutbildade än för de lågutbildade. En möjlig förklaring till att högutbildade hade en snabbare karriär var att de yttrade sig mer än lågutbildade under lokala partimöten och sammanträden i kommunala nämnder. Dessutom hade högutbildade högre ambitioner med sin politiska karriär: de ville ha fler uppdrag, gärna med mer makt.

Statsanställda tenderade att lägga ned mer tid på sina uppdrag än framförallt privatanställda, både på lång och kort sikt: statsanställda tenderade ha lång politisk erfarenhet och allokera relativt många timmar till respektive kommunalt uppdrag. Däremot tenderade de privatanställda att ha lite högre ambitioner än lokala politiker som jobbade i den offentliga sektorn.

Det kvalitativa deltagandet skiljde sig åt beroende på vilken yrkesgrupp den lokala politikern tillhörde. Överlag hade arbetare lägre kvalitativt deltagande än 
andra yrkesgrupper. Medan jordbrukarna hade drygt 17 års erfarenhet av kommunalpolitik hade arbetarna lite drygt 10 år. Tre fjärdedelar av jordbrukarna hade förverkligat sina nämndpreferenser, medan en tredjedel av arbetarna hade gjort det samma. Nästan tre fjärdedelar av företagarna uppgav att de yttrade sig nästan varje gång på lokala partimöten, men bara hälften av arbetarna uppgav samma sak. Ungefär två tredjedelar av de högre tjänstemännen, jordbrukarna och företagarna rapporterade att de yttrade sig nästan varje gång under sammanträden i kommunala nämnder, endast två femtedelar av arbetarna gjorde det samma. Inom partierna tenderade arbetarna att uppfatta sitt inflytande som relativt lågt. Arbetarna uppfattade dock sitt inflytande i kommunen som ganska jämställt med andra yrkesgrupper och arbetarna lade ned motsvarande tid på sina kommunalpolitiska uppdrag som andra lokala politiker. Dessutom tenderade arbetare att ha högre ambitioner med sina politiska karriärer jämfört med andra lokala politiker, speciellt jordbrukarna. Men risken fanns att arbetarnas höga ambitioner var svåra att förverkliga då de kvalitativa indikatorerna visade att de inte "tog för sig" i politiken på samma sätt som andra yrkesgrupper.

Personer med utländsk härkomst eller utländskt medborgarskap hade ett lägre kvalitativt deltagande än andra lokala politiker undantaget ambitionerna med den politiska karriären. Tendensen var mer uttalad bland utländska medborgare än bland personer med utländsk härkomst (oavsett medborgarskap). Även här fanns således risken att höga ambitioner inte förverkligas då personer av utländsk härkomst hade svårt att "ta för sig" i politiken. I sin tur kunde detta medföra en frustration över svårigheter att förverkliga personliga mål.

Regelbundna religiösa mötesbesökare hade tämligen lång kommunalpolitisk erfarenhet, men i övrigt oftast ett lägre kvalitativt deltagande än grupper med lägre religiös aktivitet. Förhållandet förklaras av den något högre andel äldre som fanns bland de regelbundna religiösa mötesbesökarna (äldre hade lång politisk erfarenhet och lägre aktivitet och politiska ambitioner).

Genom att studera bosättningstiden i kommunen noterades ytterligare en ledtråd till vad som gjorde att en del personer kunde göra en politisk karriär fast de bara varit bosatta ett år i kommunen: de hade tidigare varit kommunalpolitiskt aktiva $\mathrm{i}$ genomsnitt nästan tio år i en annan kommun. Det fanns vissa indikatorer på att dessa personer blivit "headhuntade", specialrekryterade till vissa uppdrag. Till 
exempel hade denna nyinflyttade grupp en hög andel förverkligade nämndpreferenser (77 procent). De fick det uppdrag de helst vill ha. I övrigt konstaterades att denna superaktiva grupp (se ovan) inte hade så mycket tid över till sina kommunala uppdrag. De lade endast ned fyra och en halv timme i veckan per uppdrag, vilket var relativt kort tid. Övriga samband mellan bosättningstid och kvalitativt deltagande kunde förklaras med ålder eller politisk erfarenhet.

Sammanfattningsvis är det utifrån analyserna av kvalitativt deltagande möjligt att konstatera att framförallt jordbrukare men också till viss del regelbundna religiösa mötesbesökare höll på att fasas ut i kommunalpolitiken på 1990-talet. De var ofta till åren komna och hade lång politiskt erfarenhet samt tenderade att ha en reducerad ambition $\mathrm{i}$ och med att de planerade avsluta sin politiska karriär. Ytterligare ett problem var att när de gamla kärntrupperna lämnade scenen hade andra grupper svårt att komma in och ta för sig. Speciellt tydligt var detta vad gäller personer med utländsk härkomst och arbetare. De var inte bara underrepresenterade numerärt, utan hade dessutom ett relativt lågt kvalitativt deltagande. På så sätt blev denna grupp dubbelt underrepresenterad.

I tabell 30 redovisas det kvalitativa deltagandet efter olika politiska egenskaper. De tre maktpositionerna - uppdrag i kommunfullmäktige, kommunstyrelse och presidium (position) - uppvisade alla ett relativt högt kvalitativt deltagande med ett undantag: de var mätta. Få av dem hade offensiva ambitioner för den politiska karriären, utan de hade främst en reducerad ambition.

Lokala politiker med flera uppdrag hade när det gäller upplevt inflytande, yttrandefrekvens och anciennitet ett högre kvalitativt deltagande än de med bara ett uppdrag. De som bara hade ett uppdrag hade högre ambitioner än de med två eller fler uppdrag. Detta berodde delvis på att unga som hade förhoppningar om en lång politisk karriär och som gärna ville ha flera uppdrag oftast inte hade hunnit skaffa sig mer än ett uppdrag. De som bara hade ett uppdrag lade ned mer tid på sitt enda uppdrag än de lokala politiker som hade två eller fler uppdrag. Detta var vad deltagaridealet förespråkare misstänkte. Detta ideal antar även att politiker med en enda syssla utför denna bättre än de med två eller fler uppdrag, men om detta förtäljde inte vår undersökning någonting om.

Skillnaderna mellan majoritet och opposition var obefintliga, förutom att de lokala politiker som tillhörde majoriteten i kommunen helt följdriktigt upplevde sig ha

$942015: 2 \mathrm{nr} 1-2 \mid$ SurveyJournalen 
större inflytande i kommunen än de som tillhörde oppositionen. Men märk väl att oppositionen inte kände sig helt maktlös.

Det är möjligt att konstatera att de enda reella skillnaderna i kvalitativt deltagande mellan anhängarna av deltagaridealet och de som var orienterade mot det väljarinriktade idealet var att de sistnämnda lade ned mer tid på sina uppdrag och rapporterade att de yttrade sig relativt ofta på lokala partimöten.

I samband med analysen av maktuppdrag borde nämnas något som inte framgick av tabell 30. Inom politiken betraktades ofta politisk erfarenhet som betydelsefullt. Man har ibland talat om en anciennitetsprincip. En av anciennitetsprincipens effekter har varit att den försvårade en snabb karriär och komplicerade för utomstående att komma in i systemet. I kommunalpolitiken innebar det att de som varit aktiva längst tid premierades vid uppdragsfördelningen före dem som hade en kortare tid bakom sig.

Låt oss jämföra anciennitetsprincipens styrka i kommunerna och riksdagen (Hagevi 1998). Låt vara att jämförelsen haltar, men utskotten i riksdagen kan sägas ha motsvarat nämnderna i kommunerna. I riksdagen var sambandet mellan position (presidium, övriga ledamöter och suppleanter) i utskotten och anciennitet (i detta fall antal år i riksdagen) starkt (Pearsons $\mathrm{r}=0$,45). I kommunerna var sambandet mellan anciennitet ( $\mathrm{d}$ v s antal år av kommunalpolitisk erfarenhet) och position i nämnderna svagare (Pearsons $\mathrm{r}=0,30$ ). Det indikerade att anciennitet inte var lika viktig på lokal nivå som på nationell nivå. I jämförelse med riksdagen borde således kommunalpolitiken vara något öppnare för utomstående.

\section{Sammanfattning kvalitativt deltagande}

Genom att studera vem som innehade politiska uppdrag i kommunerna var det möjligt att analysera olika typer av deltagande i den lokala representativa demokratin. Detta sa dock inte mycket om det kvalitativa deltagandet: individens uppfattning av deltagandets nytta, måluppfyllelse, tillfredsställelse samt grad av aktivitet under och omsorg över deltagandet. Om även kvalitativa aspekter beaktades framträdde ett tydligt mönster. Den numerära underrepresentation som framträdde vid analysen av typ av deltagande tenderade ofta ha samband med en kvalitativ underrepresentation. Grupper som var underrepresenterade numerärt var också ofta underrepresenterade i kvalitativt deltagande. På så sätt var dessa 
grupper dubbelt underrepresenterade. Samtidigt förstärkte numerärt överrepresenterade grupper sitt försprång genom att ha ett relativt högt kvalitativt deltagande. Därigenom förstärktes de skevheter som försvårade förverkligandet av demokratins kanske viktigaste normer: lika möjligheter till deltagande och inflytande.

\section{Framtiden}

Makt, inflytande och att påverka. Dessa ord är intimt förknippade med politik. Inflytande kan användas till att bevara det som uppfattas som bra och förändra det som anses vara dåligt. Det är dock sällan som politiker kan göra exakt som de vill, det finns andra aktörer som de måsta ta hänsyn till och faktorer som inte går att kontrollera. Men inom ett område har politikerna relativt stort inflytande: de kan till stor del själva bestämma politikens regler. Huvudlinjerna för kommunalpolitiken bestäms på nationell nivå av riksdag och regering, de övriga besluten är decentraliserade till lokal nivå. Det är således de lokala politikerna som till stor del bestämmer politikens regler inom kommunen. Om de lokala politikerna nu fick bestämma, hur skulle då de lokalpolitiska reglerna se ut i framtiden?

Vad som är intressant i föreliggande undersökning är hur 1990-talets lokala politiker såg på deltagande i den lokala representativa demokratin. I det följande är därför avsikten att undersöka vad de lokala politikerna ville med den lokala demokratin. De lokala politikerna ställdes inför 14 förslag som förekommit i debatten om kommunal demokrati och hade möjlighet att ange vad de tyckte om vart och ett av dem. De kunde svara "mycket bra förslag", "ganska bra förslag", "varken bra eller dåligt förslag", "ganska dåligt förslag" och "mycket dåligt förslag”. Resultatet presenteras i tabell 31. Där redovisas även opinionsbalansen (ob) som beräknas genom att subtrahera "ganska dåligt förslag" och "mycket dåligt förslag" från "mycket bra förslag" och "ganska bra förslag". Flera av de angivna förslagen kan kopplas till antingen deltagaridealet eller det väljarinriktade idealet. De förslag som kopplas till deltagaridealet är markerade med ett 
kommunalhus (茼). Förslag som har beröring med det väljarinriktade idealet är markerade med en valurna (\$).

Tabell 31 De lokala politikernas inställning till 14 förslag till att reformera demokratin 1999 (procent och opinionsbalans).

\begin{tabular}{|c|c|c|c|c|c|c|c|c|}
\hline & $\begin{array}{c}\text { Mycket } \\
\text { bra förslag }\end{array}$ & $\begin{array}{l}\text { Ganska br } \\
\text { förslag }\end{array}$ & $\begin{array}{l}\text { a Varken bra } \\
\text { eller dåligt } \\
\text { förslag }\end{array}$ & $\begin{array}{l}\text { Ganska } \\
\text { dåligt } \\
\text { förslag }\end{array}$ & $\begin{array}{l}\text { Mycket } \\
\text { dåligt } \\
\text { förslag }\end{array}$ & $\begin{array}{l}\text { Summa } \\
\text { procent }\end{array}$ & $\begin{array}{c}\text { Antal } \\
\text { svarande }\end{array}$ & $\begin{array}{c}\text { Opinions } \\
\text { balans }\end{array}$ \\
\hline $\begin{array}{l}\text { Direktsänd kommunfullmäktiges } \\
\text { sammanträden i lokal-tv }\end{array}$ & 30 & 28 & 20 & 9 & 4 & 100 & 1751 & +45 \\
\hline $\begin{array}{l}\text { Göra det möjligt att ha } \\
\text { nyval i en kommun }\end{array}$ & 21 & 34 & 24 & 13 & 7 & 100 & 1750 & +35 \\
\hline $\begin{array}{l}\text { Anordna kommun-och } \\
\text { riksdagsval vid olika tidpunkter } \\
\text { 亚Öka antalet kommunala }\end{array}$ & 29 & 24 & 11 & 18 & 18 & 100 & 1749 & +17 \\
\hline $\begin{array}{l}\text { förtroendeuppdrag } \\
\text { 亚Ge alla väljare i kommunen }\end{array}$ & 12 & 29 & 29 & 22 & 10 & 100 & 1743 & +9 \\
\hline $\begin{array}{l}\text { förslagsrätt till } \\
\text { kommunfullmäktige }\end{array}$ & 14 & 31 & 18 & 21 & 16 & 100 & 1750 & +8 \\
\hline $\begin{array}{l}\text { 孟Begränsa möjligheten för en per- } \\
\text { son att sitta i kommunfullmäktige } \\
\text { till ett par, tre mandatperioder }\end{array}$ & 18 & 26 & 18 & 24 & 14 & 100 & 1759 & +6 \\
\hline $\begin{array}{l}\text { Genomföra fler kommunala } \\
\text { folkomröstningar }\end{array}$ & 11 & 29 & 24 & 24 & 12 & 100 & 1739 & +4 \\
\hline $\begin{array}{l}\text { Införa direktvalda } \\
\text { kommundelsnämnder }\end{array}$ & 12 & 22 & 27 & 20 & 15 & 100 & 1711 & -1 \\
\hline $\begin{array}{l}\text { Införa fler bra betalda } \\
\text { politiska uppdrag }\end{array}$ & 5 & 17 & 27 & 32 & 19 & 100 & 1731 & -29 \\
\hline $\begin{array}{l}\text { förtroendeuppdrag } \\
\text { Införa könskptering till }\end{array}$ & 6 & 12 & 29 & 26 & 27 & 100 & 1728 & -35 \\
\hline $\begin{array}{l}\text { kommunala styrelser och nämnder } \\
\text { Sänka rösträttsåldern }\end{array}$ & 5 & 14 & 18 & 24 & 39 & 100 & 1747 & -44 \\
\hline $\begin{array}{l}\text { till } 16 \text { år } \\
\text { Alltid överlåta beslut i viktiga }\end{array}$ & 4 & 11 & 14 & 30 & 41 & 100 & 1751 & -56 \\
\hline $\begin{array}{l}\text { frågor till experter } \\
\& \text { Låta partierna i majoritet }\end{array}$ & 3 & 7 & 15 & 28 & 47 & 100 & 1747 & -65 \\
\hline $\begin{array}{l}\text { ensamma besätta posterna } i \\
\text { kommunstyrelsen }\end{array}$ & 4 & 7 & 9 & 26 & 54 & 100 & 1754 & -69 \\
\hline
\end{tabular}

Kommentar: Den exakta frågeformuleringen löd som följer. "Nedanstående lista omfattar ett antal förslag som förekommit i debatten om kommunal demokrati. Vilken är Din åsikt om vart och ett av dem?" Opinionsbalansen beräknas genom att subtrahera andelen "ganska dåligt förslag" eller "mycket dåligt förslag" från andelen "mycket bra förslag" eller "ganska bra förslag". 
Det förslag som de flesta av lokalpolitikerna stödde var att sända fullmäktigeförhandlingarna i lokal-tv. Förslaget betraktades nog tämligen oförargligt, varför det inte var konstigt att det fick ett omfattande medhåll $(\mathrm{ob}=+45)$.

År 2011 infördes möjligheten för kommuner, landsting och regioner att utlysa nyval. Men för 1990-talets lokalpolitiker fanns inte denna möjlighet. Någon omfattande diskussion om att införa nyval fanns inte. Att förslaget att göra det möjligt att ha nyval i en kommun ändå fick ett så brett stöd bland lokalpolitikerna 1999 var dock något överraskande $(\mathrm{ob}=+35)$. Detta kan vara en anledning till varför den kommunala nyvalsreformen var ganska okomplicerad. Förslaget att införa nyval i kommuner innebar att politikerna öppnade för möjligheten att söka stöd hos väljarna och var på så vis kopplat till det väljarinriktade idealet. För att markera kopplingen till det väljarinriktade idealet är förslaget markerat med en valurna i tabell 31 (\&). Frågan inställer sig varför 1990-talets lokala politiker ville ha möjlighet att utlysa nyval i sin kommun. Det var möjligt att flera lokala politiker trodde att nyval kunde vara en lösning på olika samarbetsproblem eller på problem med att skapa hållbara majoriteter i kommunen. Men frågan hörde också till viss del samman med önskemålet om att ha skilda valdagar. Det var vanligare att de som tyckte att skilda valdagar till kommun och riksdag var ett bra förslag också ville ha möjligheten till att utlysa nyval $(o b=+55)$ än vad det var bland de som tyckte att skilda valdagar var ett dåligt förslag $(\mathrm{ob}=+12)$. Det var också troligt att det fanns ett element av revanschlusta i viljan att ha möjlighet till nyval: det var vanligare att lokala politiker som befann sig i opposition önskade sig möjligheten att ha nyval (ob=+53) än de som befann sig i majoritet $(o b=+21)$.

Förslaget om skilda valdagar kunde till viss del också varit kopplat till det väljarinriktade idealet (\&), då kontakten med väljarna stod i fokus. De flesta lokala politiker var positiva till skilda valdagar för kommunal- och riksdagsval $(o b=+17)$. Till skillnad från svaren om tv-utsändningar av fullmäktigemöten och kommunala nyval var det dock fler som hade en klar och tydlig åsikt om skilda valdagar: andelen som svarat "varken bra eller dåligt förslag" var förhållandevis liten. Detta indikerade att frågan var politiserad och att det fanns skillnader mellan de lokala politikerna som hade samband med partitillhörighet (se nedan). 
Förslaget att öka antalet kommunala förtroendeuppdrag fick ett blandat mottagande $(o b=+9)$. Detta förslag är kopplat till deltagaridealet, varför det $\mathrm{i}$ tabell 31 är markerat med ett kommunalhus (酉). Ett alternativt motiv till fler uppdrag - som ofta framhålls av statsvetare - är att politiker generellt vill att det ska finnas många uppdrag då det underlättar deras möjligheter att göra politisk karriär (se Hibbing 1991; Hagevi 1998).

Förslaget om att väljarna skulle fă förslagsrätt i fullmäktige möttes med blandade reaktioner $(\mathrm{ob}=+8)$. Förslaget hade både deltagaridealiska inslag (medborgarna deltog när de lade förslag) som direktdemokratiska inslag (medborgarna skulle, utan mellanhänder, få lägga förslag, men dock ej fatta beslut).

I många politiska system tillämpas vad som på engelska kallas "term limit”, vilket kan översättas med periodbegränsning: politikerna får inte väljas om hur ofta som helst, utan får sitta högst ett par, tre mandatperioder. ${ }^{11}$ Man kan tänka sig att deltagardemokrater stödjer ett sådant förslag mer än de som är orienterade åt det väljarinriktade idealet (槛). Detta eftersom en periodbegränsning antagligen skulle öka omsättningen bland kommunalpolitikerna och göra det möjligt för fler att inneha viktiga förtroendeuppdrag. Det finns också några argument till att inte stödja förslaget om periodbegränsning. Risken är att kommunalpolitiken i onödan dräneras på politisk kompetens. En nackdel är att väljarna inte kan rösta bort politiker eller ge stöd åt politiker när de automatiskt måste avgå på grund av periodbegränsning. På så sätt förhindras väljarna att ge uttryck för sin vilja. Lokala politiker som vill fortsätta med sitt värv kan dessutom av privata skäl vara motståndare till periodbegränsning. I föreliggande undersökning var de lokala politikerna kluvna $\mathrm{i}$ åsikterna om att begränsa möjligheten för en person att sitta $\mathrm{i}$ kommunfullmäktige till ett par, tre mandatperioder $(\mathrm{ob}=+6)$. En viktig skiljelinje gick mellan de som satt i kommunfullmäktige $(\mathrm{ob}=-5)$ och de som inte satt $\mathrm{i}$ fullmäktige $(\mathrm{ob}=+23)$.

Förslaget om fler kommunala folkomröstningar fick också ett kluvet mottagande $(o b=+4)$. Samma sak gällde förslaget om direktvalda kommun- eller stadsdelsnämnder $(\mathrm{ob}=-1)$.

Ett förslag som till stor del överensstämde med det väljarinriktade idealet var att tillsätta fler välbetalda politiker (ঊ). Tankegången kan då vara som följer: avskaffa så många fritidspolitiker som möjligt och samla makten hos ett litet antal 
heltidsanställda professionella politiker som verkligen kan sina saker och som väljarna kan rösta fram eller bort. Det var dock möjligt att flera lokala politiker som var orienterade åt det väljarinriktade idealet menade att även antalet professionella politiker borde minska. De flesta lokala politiker var motståndare till fler professionella politiker $(\mathrm{ob}=-29)$.

Medan förslaget om att öka andelen förtroendeuppdrag i kommunerna fick ett blandat mottagande ( $\mathrm{ob}=+9$, se ovan), var de lokala politikerna övervägande negativa till förslaget att minska antalet förtroendeuppdrag $(o b=-35)$. Förslaget att minska antalet kommunalt förtroendevalda hörde samman med det väljarinriktade idealet (\&). Det kan synas vara naturligt att de som ville att antalet förtroendevalda ska öka, även ansåg att det är ett dåligt förslag att minska antalet förtroendevalda. Det fanns också ett sådant samband som var starkt (Pearsons r=0,71). Men det fanns även andra möjliga kombinationer. Somliga kunde till exempel tycka att förhållandena var bra som de var och ville därför varken öka eller minska antalet förtroendevalda. Genom att korstabulera svaren på de båda frågorna var det möjligt att få lite mer information om hur de lokala politikerna kunde tänkas resonera (redovisas ej i tabell). Av de lokala politikerna tyckte 37 procent att det var ett bra förslag att öka antalet förtroendevalda och att det var ett dåligt förslag att minska antalet. Denna åsikt var helt i överensstämmelse med deltagaridealet. Dessutom uppgav 8 procent av de lokala politikerna att det var dåligt att minska antalet förtroendeuppdrag, men att förslaget att öka antalet förtroendeuppdrag varken var bra eller dåligt. Detta kan ses som ett vagare stöd för deltagaridealet. Den motsatta åsikten - att ett ökat antalet förtroendevalda var ett dåligt förslag och att minska antalet förtroendevalda var ett bra förslag omfattade 16 procent av de förtroendevalda. Denna attityd var i överensstämmelse med det väljarinriktade idealet. Även i detta fall fanns en grupp som kunde betraktas ge ett svagare stöd för det väljarinriktade idealet: åtta procent tyckte att det var dåligt att öka antalet förtroendeuppdrag och att det varken var bra eller dåligt att minska detta antal. Åtta procent av de lokala politikerna ansåg att båda förslagen var dåliga, vilket rimligtvis borde betyda att de tycker att det är bra som det är. Av de lokala politikerna tyckte 19 procent att båda förslagen varken var bra eller dåliga, vilket troligtvis indikerade att de inte tyckte frågan var så starkt kopplad till den kommunala demokratins väl och ve. ${ }^{12}$ Analysen av sambandet mellan de båda frågorna om antalet förtroendeuppdrag visade att stödet för 
deltagaridealet kanske inte var lika utbrett i politikens praktiska utformning som till exempel demokratiidealskalan gav uttryck för (se det tidigare avsnittet "Två levande demokratiideal", s. 27). Lite drygt en tredjedel gav klart deltagaridealiska åsikter. Ungefär hälften så många uttryckte istället åsikter som överensstämmer med det väljarinriktade idealet.

De flesta lokala politiker tyckte att det var ett dåligt förslag att införa könskvotering till kommunala styrelser och nämnder $(\mathrm{ob}=-44)$. Det samma gällde förslaget att sänka rösträttsåldern till 16 år $(\mathrm{ob}=-56)$. Förslaget att alltid överlåta beslut i viktiga frågor till experter mötte kraftigt motstånd från de lokala politikerna ( $\mathrm{ob}=-65)$. Eftersom det var de lokala politikerna som skulle överlämna beslutanderätten till experterna kanske resultatet inte var ägnat att förvåna. Men det bör framhållas att förslaget att avskaffa de folkvalda politikernas beslutanderätt i viktiga frågor var djupt odemokratiskt. De viktigaste besluten skulle fråntas möjligheten till folkligt inflytande och demokratisk kontroll. Det var därför istället anmärkningsvärt att var tionde lokal politiker tyckte att förslaget var mycket eller ganska bra och att knappt hälften tog klart avstånd från förslaget.

Förslaget om majoritetsstyre kunde sägas ligga i linje med det väljarinriktade idealet ( Istället för att tillsätta kommunstyrelsen proportionellt skulle majoriteten få utse hela kommunstyrelsen. Rollen som majoritet och opposition skulle därmed göras klarare. Majoriteten skulle ensam ansvara över de politiska besluten. Anhängarna av det väljarinriktade idealet torde anse att detta skulle gynna väljarnas möjlighet till ansvarutkrävande. Få av de lokala politikerna tyckte att förslaget var bra (ob=-69). Åsikten var i stort sett samma oavsett om den lokala politikern tillhörde majoriteten eller oppositionen i kommunen.

\section{Partierna om framtiden}

Genom att analysera stödet för reformförslagen efter parti erhålls bland annat information om vilka av förslagen som är partipolitiserade. Med partipolitiserad menas att majoriteterna i de olika partierna har skilda åsikter om att förslaget är bra eller dåligt. Tabell 32 redovisar opinionsbalansen för de 14 förslagen om demokratiska reformer inom respektive parti. 
Tabell 32 De lokala politikernas inställning till 14 förslag för att reformera demokratin 1999, efter parti (opinionsbalans).

\begin{tabular}{|c|c|c|c|c|c|c|c|c|}
\hline & \multicolumn{8}{|c|}{ Parti } \\
\hline & $v$ & $s$ & c & $f p$ & $m$ & $k d$ & $m p$ & övriga \\
\hline $\begin{array}{l}\text { Direktsänd kommunfullmäktiges } \\
\text { sammanträden i lokal-tv }\end{array}$ & +74 & +56 & +49 & +50 & +43 & +61 & +63 & +74 \\
\hline $\begin{array}{l}\text { Göra det möjligt att ha nyval i en } \\
\text { kommun }\end{array}$ & +41 & +13 & +36 & +52 & +51 & +39 & +59 & +63 \\
\hline $\begin{array}{l}\text { Anordna kommun-och } \\
\text { riksdagsval vid olika tidpunkter }\end{array}$ & -4 & -18 & +26 & +74 & +58 & +12 & +26 & +23 \\
\hline $\begin{array}{l}\text { 푱a antalet kommunala } \\
\text { förtroendeuppdrag }\end{array}$ & +24 & +30 & +8 & +45 & -41 & -27 & +23 & +2 \\
\hline $\begin{array}{l}\text { 亚Ge alla väljare i kommunen } \\
\text { förslagsrätt till } \\
\text { kommunfullmäktige }\end{array}$ & +41 & +2 & +16 & +6 & -17 & +15 & +68 & +21 \\
\hline $\begin{array}{l}\text { son att sitta i kommunfullmäktige } \\
\text { till ett par, tre mandatperioder }\end{array}$ & +27 & -1 & -7 & -4 & +2 & +13 & +54 & +7 \\
\hline $\begin{array}{l}\text { Genomföra fler kommunala } \\
\text { folkomröstningar }\end{array}$ & +36 & -17 & +8 & +13 & -6 & +6 & +76 & +38 \\
\hline $\begin{array}{l}\text { Införa direktvalda } \\
\text { kommundelsnämnder }\end{array}$ & +22 & -19 & +25 & +17 & -21 & +10 & +34 & +21 \\
\hline $\begin{array}{l}\text { Införa fler bra betalda politiska } \\
\text { uppdrag }\end{array}$ & -50 & -33 & -20 & -17 & -18 & -32 & -36 & -44 \\
\hline $\begin{array}{l}\text { Minska antalet kommunala } \\
\text { förtroendeuppdrag }\end{array}$ & -52 & -63 & -41 & -68 & +21 & -11 & -39 & -25 \\
\hline $\begin{array}{l}\text { Införa könskvotering till } \\
\text { kommunala styrelser och nämnder }\end{array}$ & +4 & -19 & -67 & -68 & -83 & -68 & +7 & -70 \\
\hline Sänka rösträttsåldern till 16 år & -38 & -66 & -46 & -57 & -73 & -51 & +30 & -42 \\
\hline $\begin{array}{l}\text { Alltid överlåta beslut i viktiga } \\
\text { frågor till experter } \\
\text { Låta partierna i majoritet }\end{array}$ & -76 & -72 & -73 & -71 & -49 & -59 & -76 & -45 \\
\hline $\begin{array}{l}\text { ensamma besätta posterna } i \\
\text { kommunstyrelsen }\end{array}$ & -76 & -66 & -82 & -75 & -56 & -80 & -88 & -67 \\
\hline
\end{tabular}

Kommentar: Den exakta frågeformuleringen löd som följer. "Nedanstående lista omfattar ett antal förslag som förekommit i debatten om kommunal demokrati. Vilken är Din åsikt om vart och ett av dem?" Opinionsbalansen beräknas genom att subtrahera andelen "ganska dåligt förslag" eller "mycket dåligt förslag" från andelen "mycket bra förslag" eller "ganska bra förslag".

Även om förslaget om direktsända fullmäktiges sammanträden i lokal-tv kan låta oförargligt och att stödet för förslaget var starkt bland de lokala politikerna fanns det betydande skillnader mellan partierna. Förslaget stöddes främst av vänsterpartisterna $(\mathrm{ob}=+74)$ och minst av moderaterna $(\mathrm{ob}=+43)$. Trots 
skillnaderna var dock stödet för att sända kommunfullmäktiges sammanträden i lokal-tv stort i samtliga partier.

I alla partier fanns en majoritet som stödde förslaget att göra det möjligt med nyval $i$ en kommun. Bland socialdemokraterna var dock stödet märkbart svagare än bland övriga partier. Till viss del berodde detta på att många socialdemokrater ingick i kommunens styrande majoritet, vilket som tidigare visats minskade stödet för nyval. Dessutom kunde viljan till nyval sättas i samband med åsikten om skilda valdagar till kommun och riksdag. Ett eventuellt kommunalt nyval skulle sannolikt oftast att vara skilt från ett riksdagsval (se nedan).

Frågan om att anordna kommun- och riksdagsval på olika dagar var starkt partipolitiserad. Starkast var stödet bland folkpartisterna (ob=+74) och moderaterna $(\mathrm{ob}=+58)$. Lokala politiker $\mathrm{i}$ de socialistiska partierna var betydligt mer negativa till förslaget om skilda valdagar. Motståndet till skilda valdagar var starkast bland socialdemokraterna ( $\mathrm{ob}=-18)$, medan vänsterpartisterna var lite mer splittrade (ob=-4). Även som de socialistiska lokala politikerna till övervägande del tyckte att skilda valdagar var ett dåligt förslag var det noterbart att motståndet inte var speciellt omfattande.

Också förslaget att öka antalet kommunala förtroendeuppdrag var partipolitiserat. Viljan att öka antalet kommunala förtroendeuppdrag var knutet till deltagaridealet. Förslaget fick starkast stöd av folkpartisterna $(o b=+45)$. Även bland socialdemokraterna $(\mathrm{ob}=+30)$, vänsterpartisterna $(\mathrm{ob}=+24)$ och miljöpartisterna $(\mathrm{ob}=+23)$ var stödet förhållandevis starkt. Däremot tyckte de flesta moderater att förslaget att öka antalet kommunala förtroendeuppdrag var dåligt (ob=-41). Även kristdemokraterna var negativa till förslaget $(o b=-27)$. Centerpartisterna var däremot kluvna $(\mathrm{ob}=+8)$.

De flesta partier var tämligen kluvna till att ge alla väljare i kommunen förslagsrätt i kommunfullmäktige, att begränsa möjligheten för en person att sitta i kommunfullmäktige samt genomföra fler kommunala folkomröstningar. Endast miljöpartisterna $(\mathrm{ob}=+68, \mathrm{ob}=+54$ respektive $\mathrm{ob}=+76)$ och vänsterpartisterna $(o b=+41, o b=+27$ respektive $o b=+36)$ gav dessa förslag ett starkt stöd.

Stödet för att införa direktvalda kommundelsnämnder var ganska jämnt fördelat mellan partierna, undantaget moderaterna $(\mathrm{ob}=-21)$ och socialdemokraterna $(\mathrm{ob}=-$ 
19). Till skillnad från de andra partierna var dessa till övervägande del negativa till direktvalda kommundelsnämnder.

Alla partier var övervägande negativa till förslaget att införa fler bra betalda politiska uppdrag. Men det fanns skillnader i hur negativa de lokala politikerna var. Mest negativa var vänsterpartisterna $(o b=-50)$ och minst negativa var folkpartisterna $(\mathrm{ob}=-18)$ och moderaterna $(\mathrm{ob}=-17)$.

Förslaget att minska antalet kommunala förtroendeuppdrag var kopplat till det väljarinriktade idealet. Förslaget fick ett svagt stöd av moderaterna (ob=+21). Kristdemokraterna var splittrade $\mathrm{i}$ frågan $(\mathrm{ob}=+11)$. I övriga partier övervägde de lokala politiker som tycker att förslaget var dåligt.

Förslaget att införa könskvotering till kommunala styrelser och nämnder fick inget starkt stöd i partierna. Flera partier var klart negativa till förslaget om könskvotering. Mest negativa var moderaterna $(\mathrm{ob}=-83)$. Men vissa partier var splittrade: miljöpartisterna $(\mathrm{ob}=+7)$, vänsterpartisterna $(\mathrm{ob}=+4)$ och till viss del socialdemokraterna ( $\mathrm{ob}=-19)$. Till stor del berodde splittringen inom dessa partier på att kvinnor och män hade olika uppfattning om könskvotering. Kvinnor var positiva till förslaget medan män var negativa. Bland vänsterpartisterna var skillnaden mellan män $(o b=-29)$ och kvinnor $(o b=+33)$ störst. Inom socialdemokraterna (män: $o b=-37$; kvinnor: $o b=+1$ ) och miljöpartiet (män: $o b=-6$; kvinnor: $\mathrm{ob}=+24$ ) var gapet mellan könen också stort. Inom partier som var mer utpräglat negativa till förslaget om könskvotering var enigheten mellan könen större. Bland folkpartisterna (män: $o b=-70$; kvinnor: $o b=-65$ ), moderaterna (män: $\mathrm{ob}=-87$; kvinnor: $\mathrm{ob}=-75$ ) och centerpartisterna (män: $\mathrm{ob}=-78$; kvinnor: $\mathrm{ob}=-52$ ) fanns det trots allt vissa skillnader mellan kvinnor och män. Bland kristdemokraterna fanns dock en större skillnad mellan könen (män: ob=-82; kvinnor: ob=-44). ${ }^{13}$

Förslaget att sänka rösträttsåldern till 16 år fann bara nåd hos miljöpartisterna $(o b=+30)$, medan övriga partier avvisade förslaget.

Förslaget att överlåta alla viktiga beslut till experter avfärdades mycket starkt av samtliga partier. En nyansskillnad kunde dock märkas mellan å ena sidan moderaterna (ob=-49) och kristdemokraterna $(\mathrm{ob}=-59)$ och å andra sidan övriga partier (opinionsbalans mellan ob=-71 och ob=-76). 
Att låta partierna i majoritet ensamma besätta posterna i kommunstyrelsen fick ett rungande nej från de lokala politikerna oavsett parti. Mest unisont svarade miljöpartisterna $(\mathrm{ob}=-88)$ medan moderaterna svarade något mer flerstämmigt $(\mathrm{ob}=-56)$.

Några av de demokratiska reformförslagen visade sig vara ganska partipolitiserade. Fyra förslag tycktes vara mer partipolitiserade än andra: skilda valdagar till kommun och riksdag, könskvotering till kommunala styrelser och nämnder samt om antalet kommunala förtroendeuppdrag borde öka eller minska. Moderater och till viss del centerpartister tenderade att stödja förslag som förknippades med det väljarinriktade idealet medan framförallt socialdemokrater och vänsterpartister tenderade att stödja förslag som kopplades till deltagaridealet. Miljöpartisterna var också positiva till reformer i deltagaridealets riktning, men miljöpartisterna stödde också till stor del förslag som antas stärka det väljarinriktade idealet.

\section{Demokratiideal och framtiden}

Flera av de demokratiska reformförslagen var knutna till de två demokratiidealen: deltagaridealet (佥) och det väljarinriktade idealet (适). Låt oss studera åsiktsskillnaderna mellan lokala politiker som var orienterade mot deltagaridealet respektive det väljarinriktade idealet. Åsiktsskillnaderna studeras med hjälp av procentdifferens. Procentdifferensen beräknas genom att subtrahera de som tyckte att ett förslag var mycket eller ganska bra bland anhängarna av det väljarinriktade idealet från de som tyckte samma förslag var mycket eller ganska bra bland anhängarna av deltagaridealet. Sättet att beräkna procentdifferensen innebar att om stödet bland anhängarna av deltagaridealet var större än bland anhängarna av det väljarinriktade idealet var procentdifferensen positiv $(+)$, i annat fall är procentdifferensen negativ (-). I tabell 33 finns en sammanställning åsiktsskillnaderna mellan lokala politiker orienterade mot deltagaridealet och det väljarinriktade idealet 1999. De förslag som är kopplade till det väljarinriktade idealet är markerade med en valurna ( $)$ och då bör procentdifferensen vara negativ. Förslag som är kopplade till deltagaridealet är markerade med ett kommunalhus (骨) och då bör procentdifferensen vara positiv. 
Tabell 33 Skillnader i inställning till 14 förslag till att reformera demokratin 1999, efter lokala politikers demokratiideal (procentdifferens).

\begin{tabular}{|c|c|}
\hline Reformförslag & $\begin{array}{c}\text { Procentdifferens mellan } \\
\text { deltagaridealet och det } \\
\text { väljarinriktade idealet }\end{array}$ \\
\hline Direktsänd kommunfullmäktiges sammanträden i lokal-tv & +10 \\
\hline Göra det möjligt att ha nyval i en kommun & -21 \\
\hline Anordna kommun-och riksdagsval vid olika tidpunkter & -17 \\
\hline 亚Öka antalet kommunala förtroendeuppdrag & +41 \\
\hline 亚Ge alla väljare $i$ kommunen förslagsrätt till kommunfullmäktige & +10 \\
\hline \multicolumn{2}{|l|}{ 亚Begränsa möjligheten för en person att sitta i kommunfullmäktige } \\
\hline till ett par, tre mandatperioder & -15 \\
\hline Genomföra fler kommunala folkomröstningar & 0 \\
\hline Införa direktvalda kommundelsnämnder & +11 \\
\hline Införa fler bra betalda politiska uppdrag & -16 \\
\hline Minska antalet kommunala förtroendeuppdrag & -64 \\
\hline Sänka rösträttsåldern till 16 år & +6 \\
\hline Införa könskvotering till kommunala styrelser och nämnder & +17 \\
\hline Alltid överlåta beslut i viktiga frågor till experter & -10 \\
\hline Låta partierna i majoritet ensamma besätta posterna $i$ kommunstyrelsen & -14 \\
\hline
\end{tabular}

Kommentar: Den exakta frågeformuleringen löd som följer. "Nedanstående lista omfattar ett antal förslag som förekommit i debatten om kommunal demokrati. Vilken är Din åsikt om vart och ett av dem?" Procentdifferensen beräknas genom att subtrahera andelen som tyckte att ett förslag var mycket eller ganska bra bland anhängarna av det väljarinriktade idealet från motsvarande andel bland anhängarna av deltagaridealet. För operationalisering av anhängare av deltagaridealet och det väljarinriktade idealet, se tabell 12.

Samtliga förslag som var i överensstämmelse med det väljarinriktade idealet fick starkare stöd av lokala politiker som var orienterade mot detta ideal än bland anhängarna av deltagaridealet. Förhållandet var det motsatta när förslagen var i överensstämmelse med deltagaridealet. Skillnaderna var oftast inte stora, men vid de fall då förslagen i tabell 33 är markerade med ett kommunalhus (tecknet för deltagarideal) är procentdifferensen positiv och vid de förslag som är markerade med en valurna (tecknet för det väljarinriktade idealet) är procentdifferensen negativ. 


\section{Väljare och valda}

I en representativ demokrati är det inte bara av betydelse vad de valda anser, utan även väljarnas åsikter är väsentliga. Det är väljarna de valda avser att representera. Det är sannolikt omöjligt att upprätthålla ett demokratiskt styre om inte medborgarna själva är övertygade demokrater (Almond \& Verba 1963). Det är därför av stort intresse att undersöka medborgarnas syn på de demokratiska reformförslagen och att jämföra medborgarnas åsikter med de lokala politikernas. I den tidigare nämnda surveyundersökningen av SOM-institutet hade ett representativt urval av den svenska befolkningen 18-80 år tillfrågats om deras åsikter om demokrati. Tyvärr överensstämmer endast fem av frågorna om demokratiska reformförslag i enkäten till svenska befolkningen med motsvarande frågor i enkäten till lokalpolitikerna. Dessa redovisas i tabell 34. Endast ett av dessa förslag berör något av de två demokratiideal som inriktas mot deltagare och väljare: anordna kommun- och riksdagsval vid skilda tidpunkter ( $)$.

Tabell 34 Svenska folkets inställning till 5 förslag till att reformera demokratin 1998 (procent och opinionsbalans).

\begin{tabular}{|c|c|c|c|c|c|c|c|c|}
\hline & $\begin{array}{l}\text { Mycket bra } \\
\text { förslag }\end{array}$ & $\begin{array}{c}\text { Ganska br } \\
\text { forslag }\end{array}$ & $\begin{array}{l}\text { Varken bra } \\
\text { eller dåligt } \\
\text { förslag }\end{array}$ & $\begin{array}{c}\text { Ganska } \\
\text { dåligt } \\
\text { förslag }\end{array}$ & $\begin{array}{l}\text { Mycket } \\
\text { dåligt } \\
\text { förslag }\end{array}$ & $\begin{array}{l}\text { Summa } \\
\text { procent }\end{array}$ & $\begin{array}{c}\text { Antal } \\
\text { svarande }\end{array}$ & $\begin{array}{c}\text { Opinions- } \\
\text { balans }\end{array}$ \\
\hline $\begin{array}{l}\text { Alltid överlåta beslut } i \\
\text { viktiga frågor till experter }\end{array}$ & 20 & 32 & 25 & 15 & 8 & 100 & 1669 & +29 \\
\hline $\begin{array}{l}\text { Genomföra fler nationella } \\
\text { folkomröstningar }\end{array}$ & 11 & 29 & 35 & 16 & 9 & 100 & 1666 & +15 \\
\hline $\begin{array}{l}\text { Anordna kommun- och } \\
\text { riksdagsval vid olika } \\
\text { tidpunkter }\end{array}$ & 12 & 16 & 34 & 19 & 19 & 100 & 1558 & -10 \\
\hline $\begin{array}{l}\text { Införa könskvotering till } \\
\text { offentliga styrelser och } \\
\text { nämnder }\end{array}$ & 6 & 13 & 35 & 23 & 23 & 100 & 1669 & -27 \\
\hline $\begin{array}{l}\text { Sänka rösträttsåldern till } 16 \\
\text { år }\end{array}$ & 2 & 7 & 14 & 33 & 44 & 100 & 1688 & -68 \\
\hline
\end{tabular}

Kommentar: Data om svenska befolkningens åsikter är hämtade från Oscarsson 1999 s 16 och SOMundersökningen 1998, SOM-institutet, Göteborgs universitet. Opinionsbalansen beräknas genom att subtrahera andelen "ganska dåligt förslag" eller "mycket dåligt förslag" från andelen "mycket bra förslag" eller "ganska bra förslag". 
Det förslag som fick starkast stöd av väljarna valåret 1998 var det som ovan beskrevs som starkt anti-demokratiskt. En majoritet av den svenska befolkningen tyckte att det skulle ha varit ett mycket eller ett ganska bra förslag att alltid överlåta beslut $i$ viktiga frågor till experter $(o b=+29)$. Det förslag som fick näst starkast stöd hade dock starka direktdemokratiska inslag. Av den svenska befolkningen tyckte de flesta att fler nationella folkomröstningar var ett mycket eller ganska bra förslag $(o b=+15)$. Den svenska befolkningen var splittrad i frågan om skilda valdagar till kommun och riksdag, även om de svarande som tycker att förslaget var dåligt var något fler $(o b=-10)$. I övrigt var väljarna övervägande negativa till könskvotering (ob=-27) och sänkt rösträttsålder till 16 år (ob=-68).

Jämför med det politiska system som lokalpolitikerna var verksamma i 1990, ville de flesta väljare att det skulle ha varit mycket annorlunda. På den representativa nivån önskade sig väljarna mer expertstyre, vilket borde ha inneburit mindre inflytande för politiker och troligtvis även färre politiker. Samtidigt ville medborgarna ha ökat direktdemokratiskt inflytande via fler kommunala folkomröstningar. ${ }^{14} \mathrm{I}$ dess frågor skilde sig väljarnas åsikter från de lokala politikernas. Det framgår vid en jämförelse mellan opinionsbalansen bland de lokala politikerna och den svenska befolkningen i slutet av 1990-talet som presenteras i tabell 35.

Tabell 35 En jämförelse mellan svenska folkets (1998) och lokala politikers (1999) inställning till fem förslag till att reformera demokratin (opinionsbalans).

\begin{tabular}{lcc}
\hline & $\begin{array}{c}\text { Svenska } \\
\text { befolkningen }\end{array}$ & $\begin{array}{c}\text { Lokala } \\
\text { politiker }\end{array}$ \\
\hline Alltid överlåta beslut i viktiga frågor till experter & +29 & -65 \\
Genomföra fler nationella/kommunala folkomröstningar & +15 & +4 \\
đAnordna kommun- och riksdagsval vid olika tidpunkter & -10 & +17 \\
Införa könskvotering till offentliga/kommunala styrelser och nämnder & -27 & -44 \\
Sänka rösträttsåldern till 16 år & -68 & -56 \\
\hline
\end{tabular}

Kommentar: Data om svenska befolkningens åsikter är hämtade från Oscarsson 1999 s 16 och SOMundersökningen 1998, SOM-Institutet, Göteborgs universitet. Opinionsbalansen beräknas genom att subtrahera "ganska dåligt förslag" och "mycket dåligt förslag" från "mycket bra förslag" och "ganska bra förslag". 
De lokala politikerna och den svenska befolkningen hade diametrala åsikter om förslaget att överlåta beslut $i$ viktiga frågor till experter (politiker: $o b=-65$ respektive väljare: $o b=+29)$. Medan de lokala politikerna var splittrade över frågan om fler kommunala folkomröstningar $(\mathrm{ob}=+4)$, tyckte de flesta väljarna att det var en bra idé $(o b=+15)$. Som synes var frågorna olika formulerade för de lokala politikerna och för svenska befolkningen. För de lokala politikerna gällde frågan folkomröstningar på kommunal nivå, för svenska befolkningen folkomröstningar på nationell nivå. Det är ovisst hur de skilda frågeformuleringarna påverkade svaren.

Väljarna var relativt splittrade i frågan om att anordna kommun- och riksdagsval vid olika tidpunkter, men de var till övervägande del negativa (ob=-10). De lokala politikerna var istället till största del positiva till förslaget $(\mathrm{ob}=+17)$. Frågan om könskvotering var lite annorlunda formulerad till väljarna än till de lokala politikerna. Väljarna tillfrågades om könskvotering i offentliga styrelser och nämnder, vilket således gäller organ på kommunal nivå, landstingsnivå och statlig nivå. Frågan till de lokala politikerna var smalare i omfattning då den endast gällde könskvotering i kommunala styrelser och nämnder. Väljarna var mindre negativa till att införa könskvotering till offentliga styrelser $(o b=-27)$ än vad de lokala politikerna var angående kommunala styrelser och nämnder (ob=-44). Beträffande sänkt rösträttsåldern till 16 år var väljare och valda relativt eniga om att det var ett dåligt förslag. Men faktum kvarstår: av fem undersökta demokratiska reformförslag fanns ofta stora åsiktsskillnader mellan väljare och lokala politiker i centrala demokratiska frågor.

Som tidigare konstaterats har antalet kommunala förtroendeuppdrag minskat, trots att 1990-talets lokala politiker inte stödde en sådan utveckling. De flesta ville istället öka antalet förtroendeuppdrag. Förhållandet var underligt då de lokala politikerna själva bestämde antalet politiska förtroendeuppdrag i kommunen. De här redovisade uppgifterna kan dock vara en möjlig förklaring till detta något motsägelsefulla förhållande. Även om de lokala politikerna formellt kunde besluta vad de vill måste de reellt ta hänsyn till andra aktörer $\mathrm{i}$ den representativa demokratin. En i högsta grad legitim aktör att ta hänsyn till var valmanskåren. Väljarna hade sympatier för expertstyre, något som inte överensstämmer med deltagaridealet. Kan det varit så att de lokala politikerna kände av meningsskiljaktigheterna mellan dem och väljarna? Trodde de lokala politikerna 
att väljarna inte ville ha många kommunalt förtroendevalda? Det kunde ha varit en förklaring till att antalet kommunala förtroendeuppdrag minskade trots att en majoritet av de lokala politikerna ville motsatsen. I tabell 36 redovisas uppfattningen om väljarnas åsikter om att öka antalet kommunalt förtroendevalda för samtliga av 1990-talets lokala politiker och efter parti. De lokala politikerna hade tagit ställning till följande påstående: förslag om att kommunen ska ha fler fritidspolitiker möter ringa förståelse hos de flesta väljare.

Tabell 36 De lokala politikernas inställning till påståendet att "förslag om att kommunen ska ha fler fritidspolitiker möter ringa förståelse hos de flesta väljare" 1999, efter parti (procent och opinionsbalans).

\begin{tabular}{lccccccc}
\hline Parti & $\begin{array}{c}\text { Delvis } \\
\text { Instämmer } \\
\text { helt }\end{array}$ & $\begin{array}{c}\text { Helt } \\
\text { Instämmer } \\
\text { istort sett }\end{array}$ & $\begin{array}{c}\text { motsatt } \\
\text { asikt }\end{array}$ & $\begin{array}{c}\text { motsatt } \\
\text { asikt }\end{array}$ & $\begin{array}{c}\text { Summa } \\
\text { procent }\end{array}$ & $\begin{array}{c}\text { Antal } \\
\text { svarande }\end{array}$ & $\begin{array}{c}\text { Opinions- } \\
\text { balans }\end{array}$ \\
\hline Vänsterpartiet & 18 & 49 & 28 & 5 & 100 & 153 & +34 \\
Socialdemokraterna & 20 & 54 & 23 & 3 & 100 & 595 & +48 \\
Miljöpartiet & 31 & 50 & 16 & 3 & 100 & 80 & +62 \\
Centerpartiet & 23 & 54 & 22 & 1 & 100 & 158 & +54 \\
Folkpartiet & 17 & 51 & 30 & 2 & 100 & 136 & +36 \\
Kristdemokraterna & 23 & 48 & 26 & 3 & 100 & 151 & +42 \\
Moderaterna & 23 & 52 & 21 & 4 & 100 & 376 & +50 \\
Övriga & 23 & 55 & 20 & 2 & 100 & 56 & +56 \\
\hline Samtliga & 21 & 52 & 24 & 3 & 100 & 1709 & +46 \\
\hline
\end{tabular}

Kommentar: Frågan löd som följer. "Nedan följer ett antal påståenden om problem i dagens demokrati. Om Du ser till demokratin i Din egen kommun, hur ställer Du Dig till följande påståenden?" Varav bland annat "Förslag om att kommunen ska ha fler fritidspolitiker möter ringa förståelse hos de flesta väljare" nämndes. Opinionsbalansen beräknas genom att subtrahera "Delvis motsatt åsikt" och "Helt motsatt åsikt" från "Instämmer helt" och "Instämmer i stort sett".

Oavsett parti instämde de flesta lokala politiker helt eller i stort sett med att förslag om fler fritidspolitiker mötte ringa förståelse bland väljarna (samtliga: $\mathrm{ob}=+46$ ). En anledning till varför antalet förtroendeuppdrag i kommunerna minskade kan således ha varit att de lokala politikerna uppfattade det som en populär åtgärd bland väljarna. Mycket pekade på att de lokala politikerna i så fall hade rätt. Lokala politiker i vänsterpartiet $(\mathrm{ob}=+34)$ och folkpartiet $(\mathrm{ob}=+36)$ - två partier som i tidigare analyser i denna undersökning ofta uppvisade starkt stöd för deltagaridealet - uppfattade inte att väljarna var lika negativa till fler 
fritidspolitiker som lokalpolitiker i andra partier gjorde. Miljöpartisterna - som också uppvisade en relativ stark orientering mot deltagaridealet - uppfattade dock väljarna som mycket negativa till fler fritidspolitiker $(o b=+62)$. De lokala politikernas uppfattning att väljarna inte ville ha många fritidspolitiker kunde således ha varit en möjlig förklaring till att antalet fritidspolitiker minskade, trots de lokala politikerna själva ville motsatsen.

Det är dags att sammanfatta inställning till hur 1990-talets lokala politiker uppfattade framtidens reformutrymme för den lokala representativa demokratin. Med tanke på det stora stödet för deltagaridealet bland de lokala politikerna visade sig intresset för kommunaldemokratiska reformer vara aningen ljumt. Detta rimmade dock bättre med det faktum att de lokala politikerna - trots att de flesta var orienterade mot deltagaridealet - under 1990-talet ökade svårigheten för medborgarna att delta som förtroendevalda genom att minska antalet kommunala förtroendeuppdrag. Att de lokala politikernas handlingar inte stod i överensstämmelse med deras övertygelse kunde bero på att de uppfattade det som att väljarna var väldigt negativa till fler fritidspolitiker. De förslag som antingen var kopplade till deltagaridealet eller det väljarinriktade idealet var ofta partipolitiserade i den meningen att det fanns klara skillnader mellan partierna. Medan socialdemokrater och vänsterpartister stödde förslag som antogs stärka deltagaridealet var stödet för förslag som förknippats med det väljarinriktade idealet starkast bland moderater men även till viss del bland centerpartister.

\section{Verklighetens ideal}

Det är dags att summera undersökningen av de lokala politikerna som var verksamma i slutet av 1990-talet. Dessa lokalpolitiker var förtroendevalda i kommunfullmäktige, kommunstyrelser och kommunala nämnder. Undersökningen har visat att de flesta lokalpolitiker var anhängare av deltagaridealet. Detta ideal värnade ett utbrett politiskt deltagande bland medborgarna. Bland annat var ett av deltagaridealen att varje medborgare någon gång under sin levnad skulle ha innehaft ett politiskt förtroendeuppdrag. Ett 
förverkligande av detta ideal skulle ha underlättats om det funnits många kommunala förtroendeuppdrag. De flesta lokala politiker menade också att många kommunala förtroendeuppdrag var bra för demokratin. De tyckte också att för få väljare hade erfarenhet av att ha varit kommunalt förtroendevalda och att politikermisstron bland väljarna därför riskerade att öka. Trots detta har de lokala politikerna fattat beslut som gått i rakt motsatt riktning till deltagaridealet. Med början under 1990-talet, med revolutionen i Ragunda, har antalet kommunala förtroendeuppdrag minskat betydligt. Sedan kommunallagen förändrades 1992 har var fjärde kommunalt förtroendeuppdrag avskaffats. Utvecklingen återspeglas i antalet lokalpolitiker. Under 1990-talet minskade antalet kommunpolitiker med en tiondel, men efter det har minskningen fortsatt och 2011 hade andelen kommunpolitiker minskat med en fjärdedel sedan 1993 (Hagevi 2000:39-42; Järnberg \& Olofsson 2012:11-19). Det var de lokala politikerna själva som låg bakom dessa beslut. Förhållandet mellan de lokala politikernas åsikter och resultatet av deras beslut kan verka vara en paradox. De tyckte att många kommunalt förtroendevalda var bra för demokratin samtidigt som de minskade antalet kommunala förtroendeuppdrag.

Divergensen mellan deltagaridealet bland lokalpolitikerna i slutet av 1990-talet och den faktiska utvecklingen som de initierade kanske kan förklaras med ett bristande stöd för deltagaridealet hos de lokala politikerna. Det fanns alternativa ideal till deltagaridealet som kunde ha uppfattats som lika demokratiska. Ett sådant var det väljarinriktade idealet som accentuerade att medborgarnas vilja borde ha kanaliserats genom kommunalvalen. Enligt detta ideal skulle politikerna i kommunfullmäktige och kommunstyrelsen ha varit ansvariga inför väljarna för hela den kommunala verksamheten. Makten i kommunerna skulle därför ha koncentreras till dessa organ. Antalet kommunalt förtroendevalda behövde enligt det väljarinriktade idealet inte ha varit så många och det gjorde ingenting om de var professionella politiker.

Förvisso fanns det lokala politiker som stödde det väljarinriktade idealet - främst moderater - men de flesta lokala politiker tog avstånd från det. Istället ville de öka nämndernas inflytande på bekostnad av kommunstyrelsen och kommunalråden. Också kommunfullmäktige och dess partigrupper, lokala partiorganisationer och enskilda kommunalt förtroendevalda borde enligt de lokala politikerna ha fătt ökat inflytande. De flesta av 1990-talets lokala politiker tyckte inte att färre kommunalt 
förtroendevalda ledde till effektivare styrning av kommunens verksamhet. De hade heller inte något emot att decentralisera den kommunala makten till olika nämnder. Många professionella politiker riskerade enligt de lokala politikerna att leda till ökad politikermisstro bland väljarna. Vad gäller politikermisstron, som fram till slutet av 1990-talet stadigt hade ökat i de olika undersökningar som gjorts (Holmberg 2000), hände dock något oväntat efter millennieskiftet. Trots att antalet politiker och kommunpolitiska uppdrag fortsatte att minska ökade väljarnas förtroende för politiker och partier och var 2010 uppe i samma nivåer som uppmättes under 1970-talet (Oscarsson och Holmberg 2013). Denna utveckling går tvärtemot vad förespråkarna för deltagaridealet brukar framhäva.

När 1990-talets lokala politiker tillfrågades om de i framtiden ville öka antalet kommunala förtroendeuppdrag var de inte lika entusiastiska. Endast något fler än var tredje lokal politiker sa då obetingat ja. Var sjätte lokal politiker ville istället minska antalet förtroendeuppdrag i kommunerna. Resultatet förvånade med tanke på det starka stödet för deltagaridealet bland lokalpolitikerna 1999. Däremot överensstämde detta resultat lite bättre med den faktiska utvecklingen i kommunerna som innebar allt färre kommunala förtroendeuppdrag och färre lokalpolitiker. En fråga är dock varför stödet för deltagaridealet var svagare bland lokalpolitikerna när de ombads konkretisera vad de ville göra i framtiden?

En anledning kunde vara att de lokala politikerna tog hänsyn till vad de uppfattade vara väljarnas åsikter i slutet av 1990-talet. En överväldigande majoritet - tre av fyra lokala politiker - ansåg att förslag om att kommunen skulle ha fler fritidspolitiker mötte ringa förståelse hos de flesta väljare. Det mesta tydde på att de lokala politikernas uppfattning om väljarnas åsikter var riktig. Till skillnad från de lokala politikerna ville de flesta väljare att beslut $i$ viktiga frågor alltid skulle ha överlåtits till experter. Det allt mindre antalet lokalpolitiker behövde således inte bero på att de lokala politikerna ville detta eller att de tyckte att sådana åtgärder var nyttiga. Istället kunde de lokala politikerna ha agerat $\mathrm{i}$ respons till vad de uppfattade som dåtidens väljaropinion. Till exempel kunde de lokala politikerna i tider av nedskärningar och besparingar i den kommunala verksamheten (till exempel barnomsorg, skola, kultur och fritid) uppleva att det var viktigt att inför väljarna visa att man även sparade på den politiska administrationen. 


\section{Deltagande i den lokala representativa demokratin}

Lika möjligheter till deltagande och inflytande är en av demokratins grundläggande normer. Det är dock svårt att i verkligheten upprätthålla dessa normer. Olika samhällsgrupper kan vara över- eller underrepresenterade bland deltagarna i den lokala representativa demokratin. Om det finns samhällsgrupper som är underrepresenterade indikerar det att personer som tillhör dessa grupper inte har lika möjligheter till deltagande och inflytande i den lokala representative demokratin.

Bland de lokala politikerna fanns det stora skillnader beträffande olika samhällsgruppers representation. Bland de mest underrepresenterade grupperna var personer med utländsk härkomst, unga under 30 år, de som var 67 år och äldre, lågutbildade, arbetare och personer som arbetade i privat sektor. Bland de mest överrepresenterade grupperna var personer i övre medelåldern, högutbildade, tjänstemän, kommunal- och landstingsanställda samt religiösa mötesbesökare. Alltjämt var kvinnor något underrepresenterade, men inte i samma utsträckning som förut. Vid en separat undersökning av kommunala maktpositioner visade det sig att de nu uppräknade gruppernas under- respektive överrepresentation tenderade att skärpas. Ett undantag var dock anställningssektor där privatanställdas underrepresentation tenderade att minska bland politiker som innehade maktpositioner i kommunerna. Huvudresultatet indikerade att en av demokratins grundläggande normer var svår att upprätthålla: lika möjligheter till deltagande och inflytande.

Vilka personer som var lokala politiker hade betydelse för kontakterna mellan väljare och valda. De lokala politikernas kontaktnät var - utifrån deras egna uppgifter - starkt beroende av politikernas personliga egenskaper: deras sociala bakgrund och fritidsintressen. Kontakter med den egna yrkesgruppen, föreningen, egen könstillhörighet och åldersgrupp prioriterades. Det betydde att de grupper som politikerna själva tillhörde hade bättre tillgång till beslutsfattarnas öra än andra grupper. För den som likt deltagaridealets anhängare ville ha många och vitt förgrenade kanaler mellan väljare och valda kunde det därför ha betydelse att de lokala politikerna i större utsträckning än befolkningen i övrigt var aktiva i olika föreningar utanför partipolitiken. För den vanliga lokala politikern var det dock inte brukligt att använda massmedia för att kommunicera med väljarna. Istället var 
massmedia främst en kanal till väljarna för de lokala politiker som satt i olika maktpositioner. Massmedia var också en kanal som prioriterades mer av de lokala politiker som var orienterade mot det väljarinriktade idealet än av deltagaridealets anhängare.

Deltagande kan ske inom olika politiska sakområden. Med politiskt sakområde menas de ämnen som den politiska aktiviteten avser att påverka. Olika samhällsgruppers deltagande i den representativa demokratin skiftade beroende på vilka sakfrågor som behandlas. I kommunstyrelserna var kvinnor och personer med utländsk härkomst extra underrepresenterade. Kvinnor var också extra underrepresenterade inom verksamhetsområdet infrastruktur och skydd. Däremot var kvinnor tillsammans med pensionärer, kommun- och landstingsanställda samt regelbundna religiösa mötesbesökare överrepresenterade inom verksamhetsområdet vård och omsorg. Inom verksamhetsområdet skola och förskola var "föräldragenerationen" - personer i mellan 30-44 år som ofta hade hemmavarande barn - överrepresenterade, medan äldre, pensionärer samt personer med utländsk härkomst var extra underrepresenterade.

Genom att studera vem som innehade politiska uppdrag i kommunerna var det möjligt att analysera olika typer av deltagande i den lokala representativa demokratin. Detta sa dock inte mycket om det kvalitativa deltagandet, det vill säga individens uppfattning av deltagandets nytta, måluppfyllelse, inflytande eller individens omsorg över, tillfredsställelse av och grad av aktivitet under deltagandet. När kvalitativa aspekter beaktades framträdde ett tydligt mönster. Den numerära underrepresentation som framträdde vid analysen av typ av deltagande tenderade ofta ha samband med en kvalitativ underrepresentation. Grupper som var underrepresenterade numerärt uppvisade ofta också ett lägre kvalitativt deltagande. På så sätt var dessa grupper dubbelt underrepresenterade. Samtidigt förstärkte numerärt överrepresenterade grupper sitt försprång genom att ha ett relativt högt kvalitativt deltagande. Därigenom ökade de skevheter som försvårade förverkligandet av demokratins kanske viktigaste normer: lika möjligheter till deltagande och inflytande. 


\section{Framtidens demokratiska reformer}

Det var 1990-talets lokala politiker som till stor del bestämde reglerna för politiken i kommunerna inför millennieskiftet. Under 1990-talet inleddes en drastisk minskning av den politiska organisationen i kommunerna: mycket färre politiska uppdrag och lokalpolitiker blev resultatet. Därför var det intressant vad de lokalpolitiker som var verksamma på 1990-talet ansåg om olika demokratiska reformförslag. De flesta lokala politiker ville sända kommunfullmäktiges sammanträden i lokal-tv, införa möjligheten att ha kommunala nyval och ha skilda dagar för val till kommunfullmäktige och riksdag. Några förslag var däremot impopulära: att minska antalet kommunala förtroendeuppdrag, införa könskvotering till kommunala styrelser och nämnder, sänka rösträttsåldern till 16 år, alltid överlåta beslut i viktiga frågor till experter, låta partierna i majoritet ensamma besätta posterna i kommunstyrelsen samt införa fler bra betalda politiska uppdrag. Det sistnämnda kan så här i efterhand synas konstigt. Antalet professionella politiker har kraftigt ökat sedan 1990-talet och den arvoderade ersättningen till lokalpolitiker likaså (Hagevi 2014).

Några av de demokratiska reformförslagen visade sig vara ganska partipolitiserade. Fyra förslag tycktes vara mer partipolitiserade än andra: skilda valdagar till kommun och riksdag, könskvotering till kommunala styrelser och nämnder samt om antalet kommunala förtroendeuppdrag borde öka eller minska. Socialdemokrater och vänsterpartister tenderade att stödja förslag som antogs gynna deltagaridealet, medan främst moderater men även till viss del centerpartister stödde förslag som förknippades med det väljarinriktade idealet.

Till viss del var de lokala politikernas förslag till framtida demokratiska reformer möjliga att jämföra med väljarnas åsikter. Det var ett mycket annorlunda politiskt system än det som fanns på 1990-talet som de flesta väljare prioriterade. På den representativa nivån önskade sig väljarna mer av expertstyre, vilket borde innebära mindre inflytande för politiker och troligtvis även färre politiker. Samtidigt ville medborgarna ha ökat direktdemokratiskt inflytande via fler folkomröstningar.

Mycket pekade på att det rådde omfattande skillnader i synen på demokrati och vad som var det goda styrelseskicket mellan väljare och valda. Attityden till expertstyre och fler folkomröstningar tenderade att vara positiv bland väljarna, 
men negativ bland de lokala politikerna. De lokala politikernas negativa inställning till förslaget om fler kommunala folkomröstningar var logisk med tanke på att en stor majoritet av dem tyckte att väljarna hade dålig kunskap om kommunal politik. De lokalpolitiker som tyckte att väljarna var okunniga ville $\mathrm{i}$ minde utsträckning än andra lokalpolitiker att väljarna skulle påverka de kommunala besluten genom fler folkomröstningar.

Det är möjligt att diskrepansen i synen på demokratins utformning riskerade att leda till ökad politikermisstro och minskat förtroende för demokratiska institutioner bland medborgarna. Men i sina faktiska beslut minskade lokalpolitikerna antalet kommunala uppdrag och antalet kommunalpolitiker. På så sätt verkar det som om lokalpolitikerna beaktade väljarnas åsikter, åtminstone utifrån antagandet att lokalpolitikerna faktiskt gjorde medvetna beslut om den politiska organisationens storlek i kommunerna. Kanske är detta en del av förklaringen till att politikerförtroendet, mycket överraskande, tycks ha ökat sedan 1990-talets bottennivå.

\section{Tillbaka till framtiden}

Under 1990-talet dominerade deltagaridealet bland lokalpolitikerna. Ändå krympte de den politiska organisationen i kommunerna, ökade andelen professionella politiker och nivån på den arvoderade ersättningen för kommunalpolitiska uppdrag. Resulterade dessa förändringar i ett förändrat demokratiideal bland lokalpolitikerna? Någon återupprepning av föreliggande undersökning har inte gjorts, så en exakt jämförelse över tid är inte möjlig att göra. Men några undersökningar har genomförts där lokalpolitikernas demokratiideal varit på forskarnas agenda (Gilljam m.fl. 2010: 39-42; Karlsson \& Gilljam 2014: 74-79). Det har då framstått som om det väljarinriktade idealet dominerat bland såväl väljare som lokalpolitiker. Men även då har detta ideal varit starkast bland moderata lokalpolitiker, medan deltagaridealet varit starkast bland lokalpolitikerna i vänsterpartiet, miljöpartiet och sverigedemokraterna (Karlsson \& Gilljam 2014: 75-76). Att det bland 1990-talets moderata lokalpartier fanns ett sviktande stöd för deltagaridealet och ett jämförelsevis stort stöd för det väljarinriktade idealet kanske visade på en förestående förändring om en ökad spridning av det väljarinriktade idealet bland lokalpolitikerna. I undersökningar som gjorts senare tycks en sådan spridning noterats till de flesta partiers 
lokalpolitiker. I så fall har det ökade stödet för det väljarinriktade idealet inte avstannat. Mellan 2006 och 2010 fanns uppgifter på att det är främst i de rödgröna partierna - socialdemokraterna, miljöpartiet och vänsterpartiet - samt bland lokalpolitikernas i sverigedemokraterna som stödet för det väljarinriktade demokratiidealet hade ökat (Gilljam m.fl. 2010: 40; Karlsson \& Gilljam 2014: 76). Det tycks i så fall ha varit en anpassning bland lokalpolitikerna, antingen till de rådande förhållandena med en krympt politisk organisation i kommunerna, eller till väljarnas väljarinriktade demokratiideal.

\section{Noter}

${ }^{1}$ Två partier (miljöpartiet och vänsterpartiet) ville dock behålla miljö- och hälsoskyddsnämnden som obligatorisk nämnd.

${ }^{2}$ Mill var inte ensam i att anta att politiskt deltagande var eftersträvansvärt utan har haft många efterföljare (se t.ex. Pateman 1970; Nagel 1987; Gould 1988; Dahl 1989; Warren 1992).

${ }^{3}$ Både deltagaridealet och det väljarinriktade idealet går att dela in ytterligare i olika underkategorier. Holmberg 1999 delar in anhängarna till det väljarinriktade idealet i partidemokrater och ansvarsdemokrater. De viktiga skillnaderna mellan dessa två grupper är enligt Holmberg (1999) att partidemokrater anser att medborgarna bör välja mellan partiernas politiska program om vad de vill göra $i$ framtiden under den kommande mandatperioden. Ansvarighetsdemokrater anser att medborgarna bör välja ledare som utvärderas och ställs till ansvars $i$ efterhand då mandatperioden är slut.

${ }^{4}$ För detaljerad information om SOM-undersökningen 1998, se Lithner 1999.

${ }^{5}$ Vid frågeundersökningar finns det en tendens att svarspersonerna har lättare att ge jakande eller på annat sätt instämmande svar till påstående än att ta avstånd från dem eller inte instämma (Viscovi \& Hagevi 2016).

${ }^{6}$ I påståendena om konsensus- och konfliktnivån i kommunerna avvek lokalpolitikerna $\mathrm{i}$ övriga partier genom en mindre avvisande attityd till två påståenden: politikerna söker konflikt om småsaker: $o b=-26$ och politikerna är alltför angelägna att komma överens $o b=-39)$. 
${ }^{7}$ Ett mått på spridningen runt ett medelvärde är standardavvikelsen (s). Ju högre standardavvikelse, desto större spridning. Moderaternas standardavvikelse på demokratiidealskalan är $s=3,4$. Motsvarande värde för resterande partier är miljöpartiet $\mathrm{s}=3,1$; vänsterpartiet $\mathrm{s}=3,0 ; \quad$ kristdemokraterna $\mathrm{s}=2,9$; $\quad$ centerpartiet $\quad \mathrm{s}=2,7$; socialdemokraterna $\mathrm{s}=2,7$; folkpartiet $\mathrm{s}=2,4$.

${ }^{8}$ Andra förklaringar än generationsskifte inom moderaterna är möjliga. Med stigande ålder kanske de yngre moderaterna intog samma ståndpunkt som de äldre. Det kan också tänkas att resultatet bara gällde för den period som mätningen gjordes. En likadan mätning gjord en annan tidpunkt kunde ha givit ett annat resultat.

${ }^{9}$ Eftersom andelen svenska medborgare var så dominerande jämfört med andelen utländska medborgare fungerade inte procentdifferensen så bra som statistiskt mått. Det berodde på att procentdifferensens maxgräns nåddes snabbt. Om det inte fanns några utländska medborgare bland de lokala politikerna så skulle procentdifferensen ändå inte överstiga 5 procentenheter. Därför diskuteras i fortsättningen utländska medborgares underrepresentation i termer av kvoter: andelen utländska medborgare var en femtedel av andelen invånare med utländskt medborgarskap.

${ }^{10}$ En orsak till folkpartisternas något lägre antal timmar som de lade ned på kommunalpolitiska åtaganden var att många av folkpartisterna endast hade ett uppdrag.

${ }^{11}$ Ett känt exempel på periodbegränsning är att USA:s president endast får väljas om en gång.

${ }^{12}$ Övriga svarande är jämnt spridda på resterande tre svarsmöjligheter.

${ }^{13}$ Angående könskvotering i kommunala styrelser och nämnder: bland samtliga män är opinionsbalansen $\mathrm{ob}=-60$ och bland samtliga kvinnor är $\mathrm{ob}=-23$.

${ }^{14}$ Det är teoretiskt möjligt att kombinera åsikterna om fler folkomröstningar och fler expertbeslut i ett slags direktdemokratiskt system. Det går att tänka sig att medborgarna deltar i många folkomröstningar - kanske via Internet - och därigenom fattar beslut i de mest skilda åsikter. Besluten verkställs sedan av experter och andra tjänstemän. Det finns dock inget statistiskt signifikant samband (mätt med Pearsons $r$ ) mellan förslagen om att införa fler folkomröstningar och låta fler beslut fattas av experter. 


\section{Referenser}

Almond, G. A. \& Verba, S. (1963) The Civic Culture: Political Attitudes and Democracy in Five Nations. Princeton: Princeton University Press.

Amnå, E. (1999) Demokrati och fria folkviljor. Demokratiutredningens seminarium i Västerås 1999-04-21. http://www.demokratitorget.gov.se. Hämtat 2000-01-12.

Barber, B. (1984) Strong Democracy: Participatory Politics for a New Age. Los Angeles: University of California Press.

Bennulf, M. (1994) Miljöopinionen i Sverige. Lund: Dialogos.

Bjereld, U. \& Demker, M. (2005) I Vattumannens tid? En bok om 1968 års uppror och dess betydelse idag. Stockholm: Hjalmarsson \& Högberg.

Bromander, T. (2012) Politiska skandaler! Behandlas kvinnor och män olika $i$ massmedia? Växjö: Linnaeus University Press.

Bromander, T. (2014) "Medborgarnas misstro till massmedias rapportering av politiska skandaler", Surveyjournalen, 1(1), sid. 15-33.

Brothén, M. \& Gilljam, M. (2006) "Mellanvalsdemokrati." I Bäck, H. \& Gilljam, M. (red), Valets mekanismer. Malmö: Liber, sid. 193-216.

Dagens Nyheter 1992-06-10.

Dahl, R. (1989). Democracy and its Critics. New Haven : Yale University Press.

Dahlerup, D. (1988) "From a Small to a Large Minority: Women in Scandinavian Politics." Political Studies, 4, sid. 275-298.

Demokratiutredningen (2000) En uthållig demokrati!, SOU 2000:1. Stockholm: Fritzes offentliga publikationer.

Elofsson, S (1996) Ungdomar i kristna föreningar. Stockholm: Fritid Stockholm, Forskningsenheten.

Esaiasson, P. \& Holmberg, S. (1996): Representation from Above: Members of Parliament and Representative Democracy in Sweden. Aldershot: Dartmouth Publishing.

120 2015:2 nr 1-2| SurveyJournalen 
Esaiasson, P. Gilljam, M. \& Persson, M. (2011) "Medborgarnas demokratiuppfattningar." I Holmberg, S., Weibull, L och Oscarsson, H. (red). Lycksalighetens ö. Göteborg: SOMinstitutet, Göteborgs universitet, sid 269-277.

Gahrton, P. (1988) Vad vill de gröna? Göteborg: Bokförlaget Korpen.

Gilljam, M. \& Möller, T. (1996) "Från medlemspartier till väljarpartier." I På medborgarnas villkor. En demokratisk infrastruktur. Bilaga till betänkande av Demokratiutvecklingskommittén. SOU 1996:162. Stockholm: Fritzes.

Gilljam, M \& Jodal, O. (2002) "Medborgarnas demokratiuppfattningar." I Holmberg, S \& Weibull, L. (red) Det våras för politiken. Göteborg: SOM-institutet, Göteborgs universitet.

Gilljam, M. Karlsson, D. \& Sundell, A. (2010) Politik på hemmaplan: Tiotusen fullmäktigeledamöter tycker om politik och demokrati. Stockholm: SKL Kommentus.

Gould, C. (1988) Rethinking Democracy: Freedom and Social Cooperation in Politics, Economy and Society. Cambridge: Cambridge University Press.

Göteborgs-Posten 1997-06-09.

Hagevi, M. (1998) Bakom riksdagens fasad. Göteborg: Akademiförlaget Corona.

Hagevi, M. (2000) Professionalisering och deltagande $i$ den lokala representativa demokratin. Cefos-rapport nr 13. Centrum för forskning om offentlig sektor, Göteborgs universitet.

Hagevi, M. (2009). Politisk opinion och religiositet $i$ Västra Götaland. Lund: Sekel bokförlag.

Hagevi, M. (2014). "Fyra decenniers partistöd”, Statsvetenskaplig Tidskrift, 116(1) sid. $21-44$.

Hagevi, M. (2015) Den svenska väljaren 2014. Malmö: Gleerups.

Held, D. (1987) Models of Democracy. Cambridge: Polity Press.

Hibbing, J. (1991) Congressional Careers: Counters of Life in the U.S. House of Representatives. Chapel Hill: The University of North Carolina Press. 
Magnus Hagevi

Holmberg, S. (1981). Svenska väljare. Stockholm: Publica.

Holmberg, S. (1999) Representativ demokrati. SOU 1999:64. Demokratiutredningen skrift nr 24. Stockholm: Fakta info direkt.

Holmberg, S. (2000) Välja parti. Stockholm: Norstedts juridik.

Holmberg, S. \& Gilljam, M. (1987) Väljare och val i Sverige. Stockholm: Norstedts Juridik.

Jarl, M. (1999) Brukardeltagandets demokratiska tvetydighet. Uppsats. Nordiska statsvetarkongressen: XI. Uppsala.

Justitiedepartementet, direktiv 1999: 98 Atgärder för att stärka den medborgerliga insynen och deltagandet $i$ den kommunala demokratin, Justitiedepartementet.

Järnberg, M. \& Olofsson, J. (2012) Förtroendevalda i kommuner och landsting 2011. Stockholm: Statistiska centralbyrån.

Karlsson, D. \& Gilljam, M. (2014) "Svenska politikers demokratisyn". I Karlsson, D. \& Gilljam, M. Svenska politiker: Om de folkvalda i riksdag, landsting och kommun. Stockholm: Santérus förlag, sid 73-92.

Kim, J.-O. \& Mueller, C. W. (1978a) Introduction to Factor Analysis: What it Is and How To Do It. Newbury Park: Sage.

Kim, J.-O. \& Mueller, C. W. (1978b) Factor Analysis: Statistical Methods and Practical Issues. Newbury Park: Sage.

Kommunaktuellt 1997-06-05.

Kommunalt förtroendevalda 1995: Del 1 ,Fördelningen på nämnder, andel kvinnor, ålder, parti m.m. (1996) Stockholm: Kommentus förlag.

Lewin, L. (1970) Folket och eliterna: En studie i modern demokratisk teori. Stockholm: Almqvist \& Wiksell.

Lithner, A. (1999) "SOM-undersökningen 1998." I Holmberg, S \& Weibull, L, red Den ljusnande Framtid. Göteborg: SOM-institutet, Göteborgs universitet, sid. 401-409.

122 2015:2 nr 1-2| SurveyJournalen 
Ideal och verklighet $i$ den lokala demokratin

Mill, J.S. (1861/1992) "Considerations On Representative Government." I Mill, J.S. On Liberty And Other Essays. Oxford: Oxford University Press, sid. 202-467.

Montin, S. (1996) Kommunala förnyelseproblem: Bilaga 1 till slutbetänkande av Kommunala förnyelsekommittén. SOU 1996:169. Stockholm: Fritzes.

Montin, S. (1998) Lokala demokratiexperiment - exempel och analyser. SOU 1998:155. Stockholm: Fritzes.

Möller, T. (2015) Svensk politisk historia: Strid och samverkan under tvåhundra år. Lund: Studentlitteratur.

Nagel, J. (1987) Participation. New Jersey: Prentice-Hall.

Nerikes Allehanda 1999-09-28.

Oscarsson, H. (1999) Demokratiopinioner. SOU 1999:80. Stockholm: Fakta Info Direkt.

Oscarsson, H. \& Holmberg, S. (2013) Nya svenska väljare. Stockholm: Norstedts Juridik.

Olsen, J. (1991) Svensk demokrati i förändring. Stockholm: Carlssons.

Pateman, C. (1970) Participation and Democratic Theory. Cambridge: Cambridge University Press.

Petersson, O. (1987) Metaforernas makt. Stockholm: Carlssons.

Petersson, O.; Hermansson, J.; Micheletti, M.; Teorell, J. \& Westholm, A. (1998) Demokrati och medborgarskap: Demokratirådets rapport 1998. Stockholm: SNS förlag.

Rapp, P.-O. (2011) Remiss: Förslag till politikerorganisation i Sala kommun. Sala: Sala kommun, Kommunstyrelsen:

http://www.sala.se/Global/1\%20SALA\%20KOMMUN/04\%20Rapporter-

redovisningar/kso-remiss-

f\%c3\%b6rslag\%20till\%20ny\%20politikerorganisation\%20i\%20Sala\%20kommun.pdf (hämtat 2016-04-01).

Riksdagens konstitutionsutskott, betänkande 1990/91:KU38, Ny kommunallag.

Rosén Sundström, M. \& Sundström, M. (2010) "Ett smalare men vassare Centerparti?", Statsvetenskaplig tidskrift, 112(2): 189-202. 
Magnus Hagevi

Rothstein, B., red (1995) Demokrati som dialog: Demokratirådets rapport 1995. Stockholm: SNS Förlag.

Rousseau, J-J. (1762/1968). The Social Contract. London: Penguin Books.

SCB (1999a) Statistisk årsbok 2000. Örebro: SCB.

SCB (1999b) Befolkningsstatistik 1998. Del 3. Folkmängden efter kön, ålder och medborgarskap m. m. Örebro: SCB-Tryck.

Schumpeter, J. (1942/2008) Capitalism, Socialism and Democracy. New York: Harper Perennial.

Skeije, H. (1992) Den politiske betydningen av kjonn: En studie av norsk topp-politikk. Oslo: Institutt for samfunnsforskning.

Strandberg, U. (2008) Debatten om den kommunala självstyrelsen 1962-1994. Hedemora: Gidlunds.

Strömberg, L. \& Westerståhl, J. (1984) The New Swedish Communes: A Summary of Local Government Research. Stockholm: Liber.

Szücs, S. (1998) Democracy in the Head: A Comparative Analysis of Democratic Leadership Orientations Among Local Elites in Three Phases of Democratization. Centrum för forskning om offentlig sektor, Göteborgs universitet.

Viscovi, D. \& Hagevi, M. (2016, kommande) Enkäten: Att formulera frågor och svar. Lund: Studentlitteratur.

Warren, M. (1992) Democratic Theory and Self-Transformation. American Political Science Review, 86, sid. 8-23.

Wängnerud, L. (1998) Politikens andra sida: Om kvinnorepresentation $i$ Sveriges riksdag. Göteborg: Statsvetenskapliga institutionen, Göteborgs universitet. 